NBER WORKING PAPER SERIES

\title{
ANALYZING THE INFLUENCE OF OCCUPATIONAL LICENSING DURATION AND GRANDFATHERING ON LABOR MARKET OUTCOMES
}

\author{
Suyoun Han \\ Morris M. Kleiner \\ Working Paper 22810 \\ http://www.nber.org/papers/w22810 \\ NATIONAL BUREAU OF ECONOMIC RESEARCH \\ 1050 Massachusetts Avenue \\ Cambridge, MA 02138 \\ November 2016, Revised December 2017
}

\begin{abstract}
Previously circulated as "Analyzing the Influence of Occupational Licensing Duration on Labor Market Outcomes." We greatly appreciate the comments of Joan Gieseke, Hwikwon Ham, Mindy Marks, and Elizabeth Powers on previous versions of the paper. We especially thank participants in seminars at the American Economic Association annual meetings, Clemson University, Collegio Carlo Alberto, Labor and Employment Relations Association annual meetings, London School of Economics, Society of Labor Economists annual meetings, University of Illinois, Urbana-Champaign, University of Minnesota, Twin-Cities, and the W.E. Upjohn Institute for Employment Research for their comments. We thank the Smith Richardson Foundation and the Ewing Marion Kauffman Foundation for their financial support of our research. The views expressed here are those of the authors and do not necessarily reflect the views or policies of the Smith Richardson Foundation, the Ewing Marion Kauffman Foundation, the Federal Reserve Bank of Minneapolis, the Federal Reserve System, or the National Bureau of Economic Research.
\end{abstract}

NBER working papers are circulated for discussion and comment purposes. They have not been peer-reviewed or been subject to the review by the NBER Board of Directors that accompanies official NBER publications.

(C) 2016 by Suyoun Han and Morris M. Kleiner. All rights reserved. Short sections of text, not to exceed two paragraphs, may be quoted without explicit permission provided that full credit, including $\odot$ notice, is given to the source. 
Analyzing the Influence of Occupational Licensing Duration and Grandfathering on Labor Market Outcomes

Suyoun Han and Morris M. Kleiner

NBER Working Paper No. 22810

November 2016, Revised December 2017

JEL No. J08,J3,J38,J44,J8,J88,K0,K2,L12,L38,L51,L84,L88

\begin{abstract}
The length of time from the implementation of an occupational licensing statute (i.e., licensing duration) may matter in influencing labor market outcomes. Adding to or raising the entry barriers are likely easier once an occupation is established and has gained influence in a political jurisdiction. States often enact grandfather clauses and ratchet up requirements that protect existing workers and increase entry costs to new entrants. We analyze the labor market influence of the duration of occupational licensing statutes for 13 major universally licensed occupations over a 75-year period. These occupations comprise the vast majority of workers in these regulated occupations in the United States. We provide among the first estimates of potential economic rents to grandfathering. We find that duration years of occupational licensure are positively associated with wages for continuing and grandfathered workers. The estimates show a positive relationship of duration with hours worked, but we find moderately negative results for participation in the labor market. The universally licensed occupations, however, exhibit heterogeneity in outcomes. Consequently, unlike some other labor market public policies, such as minimum wages or direct unemployment insurance benefits, occupational licensing would likely influence labor market outcomes when measured over a longer period of time.
\end{abstract}

Suyoun Han

Department of Applied Economics

University of Minnesota

St. Paul Minnesota

hanxx598@umn.edu

Morris M. Kleiner

University of Minnesota

Humphrey School of Public Affairs

260 Humphrey Center

301 19th Street South

Minneapolis, MN 55455

and NBER

kleiner@umn.edu 


\section{Introduction}

Occupational licensure is the legal process by which governments (mostly the U.S. states but also local governments and the federal government) identify the qualifications that are required to practice a trade or profession, after which time only licensed practitioners are allowed by law to receive pay for doing the work in the occupation. This form of labor market regulation has rapidly become one of the most significant institutional factors affecting labor markets in the United States and other industrialized countries (Kleiner, 2015). Over the past several decades, the share of U.S. workers holding an occupational license has grown sharply. For example, during the 2012-2013 state legislative sessions, at least seven new occupations were licensed in at least one state-occupations ranging from scrap metal recyclers in Louisiana to body artists in the District of Columbia. ${ }^{1}$ U.S. government estimates suggest that over 1,100 occupations are regulated to some extent in at least one state, but fewer than 60 are regulated in all 50 states, showing substantial differences in which occupations states choose to regulate (Department of the Treasury Office of Economic Policy, Council of Economic Advisers, and Department of Labor, 2015).

The time from the implementation of occupational licensing laws may be important in analyzing regulation's influence on the labor market. One rationale is that states often enact grandfather clauses that protect existing workers by allowing them to practice either when licensing laws are passed or after the enactment of new regulations, even though they may not meet the current requirements. We provide among the first estimates of the labor market returns to grandfathering. In contrast, new entrants must have higher entry standards than the existing

\footnotetext{
${ }^{1}$ These data are from a LexisNexis search of statutes passed during the legislative session.
} 
members of the occupation. ${ }^{2} \mathrm{We}$, therefore, anticipate that individuals who are grandfathered would have incentives to encourage licensing and their continued participation in the occupation at pre-licensing levels of education and training. They would likely obtain economic rents by limiting supply and increasing the demand for the higher quality service. ${ }^{3}$ In the labor market, the process of older, lesser trained workers leaving the workforce or moving to other occupations and newer workers with higher entry requirements entering the field takes many years or even decades as the process works its way through the labor market, resulting in potentially higher wages. We examine duration over a 75-year period to determine the influence of occupational licensing on key labor market outcomes.

In examining the influence of occupational licensing duration on the labor market, we initially review the literature of duration effects on labor market outcomes and show that our study is the first comprehensive examination of the issue using more than one occupation and implements a substantially longer time period of analysis. More important, we also present evidence that goes beyond analyzing wage determination to examine hours worked and participation in the regulated occupation for large numbers of workers. Consistent with other findings, we show that occupational licensing raises wages in the regulated occupations and that the duration of state licenses also is associated with higher wages. We find this to be the case across a number of robustness tests, and it is also the case for grandfathered workers. In addition, the estimates show that the duration of state licensing is associated with an increase in yearly hours worked by those in the occupation by almost 2 percent, but that participation in the

\footnotetext{
${ }^{2}$ A model of grandfathering presented by Shavell (2007) assumes that if the best standard in period 1 exceeds the level of risk that would be appropriate for the expected harm, grandfathering may be desirable. If in period 2 the known harm is below a threshold, grandfathering is optimal—parties who engaged in the activity in period 1 can maintain their period 1 level of risk in period 2, but parties who enter the activity in period 2 should take the new conventionally optimal precaution for the known harm, and they have certainty of the outcome in the second period. ${ }^{3}$ Another source of rents also may be schools that chose to teach classes that are required for licensing attainment, courses for continuing education requirements, or exam preparation classes (Kleiner, 2015).
} 
occupation in the labor market declines somewhat over the first 30 years after the licensing laws are implemented. However, the labor market outcomes for the occupations we examine exhibit heterogeneity. We implement several sensitivity tests to examine the robustness of our estimates for labor market outcomes. These results are largely consistent with a monopoly model of regulation that shows gains to those in the regulated occupation through higher wages and more hours worked, but which may restrict entrants into the occupation in the long run.

\section{Reviewing Duration in the Labor Market for Licensed Occupations}

The duration of occupational statutes has been identified in previous studies as a factor that may raise wages (Law and Marks, 2009, Timmons and Thorton, 2013). In both studies, the authors examined one occupation and focused on wage determination. Our study expands on these studies by examining 13 universally licensed occupations (i.e., licensed in all states), some of which have been regulated in all states for over 100 years and others that just became universally licensed during the past decade. The number of workers in these occupations represents about 60 percent of all universally licensed workers in the United States in 2013 from our estimates using the American Community Survey (ACS). These occupations were chosen because the date of initial licensure was available, there were sufficient observations in the census for statistical analysis, and that the vast majority of workers must obtain a license in order to work (Gittleman and Kleiner, 2016). Also, the states that licensed these occupations regulated them at different times, allowing for a difference-in-differences estimation strategy.

The Growth and Wage Effects of Occupational Licensing

Occupational licensing has grown to be one of the largest institutions in the U.S. labor market (Kleiner and Krueger, 2013). To illustrate, funeral attendants are licensed in nine states and florists in only one state. Estimates from national surveys find that the wages of unlicensed 
workers are 8 to 15 percent lower than those of licensed workers with similar levels of education, training, and experience (Kleiner, 2006, Kleiner and Krueger, 2013, Gittleman, Klee, and Kleiner, forthcoming). At the upper end, Kleiner and Krueger (2013) find that licensing at the state level confers a wage premium of around 17 percent, and the combination of state and either federal or local licensing has an estimated impact of around 25 percent. Local licenses by themselves are not associated with higher wages, and certification has a smaller effect on wages using estimates from data from the Survey of Income and Program Participation (Gittleman, Klee, and Kleiner, forthcoming).

Unlike the minimum wage or unemployment insurance which requires all employers that are covered by the law to pay the new wage or transfer payment immediately, occupational licensing allows individuals who are working in the occupation, but do not meet the current licensing requirements, to continue working. This practice is called "grandfathering." In addition, the regulated occupation generally has the ability to ratchet up the requirements-that is, raise the requirements for initial entry or movement into the occupation from other political jurisdictions with minimal constraints from policy makers (Wheelan, 1999). Again, individuals who do not meet the current requirements are allowed to keep working with permission from the government. In our analysis, we examine how time from initial licensure, which we call duration, influences key labor market outcomes such as wages, hours worked, and participation in the workforce.

The Role of Different Institutions on Wage Determination and Labor Market Outcomes

A helpful analogy of the influence of institutions in the labor market can be drawn from unions. When unions first organize a firm or establishment, the wage increases are generally small (Freeman and Kleiner, 1990, DiNardo and Lee, 2004, Lee and Mas, 2012). However, 
cross-sectional estimates of the impact of unions are between 15 to 20 percent (Hirsch and Macpherson, 2013). The additional cost of having a union worker is approximately $\$ 40,500$ over the course of that worker's employment with the firm (Lee and Mas, 2012). Moreover, unions appear to raise the wages and benefits with a statistically significant effect the longer they are in an establishment (Freeman and Kleiner, 1990). We examine whether these wage outcomes may also be the case for occupational licensing.

Unions may raise wages through collective bargaining and withholding their labor services through concerted activities to gain wages and benefits. On the other hand, occupational licensing could raise wages by choosing the right set of regulations to restrict supply and limit the tasks of unlicensed workers, and thus enhance demand by signaling and education that they are providing a higher quality service (Friedman, 1962, Spence, 1973). In a manner similar to unions, the institutional mechanism and design that occupational licensing uses also takes time to implement and the full effects may only reach fruition over several decades of strengthening these rules (Hurwicz, 1973).

\section{Background on Grandfathering and Ratcheting Requirements}

Initially, the influence of licensing duration on labor market outcomes was identified in a National Bureau of Economic Research volume published in 1945 by Milton Friedman and Simon Kuznets (Friedman and Kuznets, 1945). They noted that in 1911, the American Medical Association, through the implementation of the Flexner Report, ratcheted up requirements for becoming a doctor through tougher admissions requirements, length of education in medical school, and limits on the number of new openings for medical education (Beck, 2004). While increasing the requirements for graduation from medical school and pushing for tougher licensing, the Flexner Report did not require currently working doctors to meet the same higher 
requirements; this was a classic case of grandfathering (Beck, 2004). Friedman and Kuznets went on to examine the influence of the regulations more than 20 years later in the late 1930s, and they found that doctors were able to raise their wages by 17 percent more than dentists, who did not substantially change their requirements. This example illustrates how an occupation can raise wages that involved rents to those who were in the occupation and how entry requirements for an occupation were raised for just new entrants.

More recent estimates of the influence of the length of licensing statutes on wage determination include results for massage therapists, nurses, lawyers, and barbers (Law and Marks, 2009, Pagliero, 2010, Timmons and Thornton, 2010, Timmons and Thornton, 2013). The main results suggest that for specific occupations such as massage therapists and barbers, the length of time that a licensing statute has been in place enhances the earnings of these practitioners, but little evidence of the influence of duration was found for nurses (Law and Marks, 2013). However, the estimates are limited to these occupations over a relatively short time period. Our estimates expand upon and provide evidence beyond simply the wage determination effects of licensing duration on labor market outcomes.

Although not explicitly addressed, the process occurs by allowing current practitioners to avoid the explicit general and specific education requirements, internships, tests, continuing education mandates, and good moral character investigations, assuming that they were in good standing prior to the new licensing laws. To the extent that these requirements raise marginal productivity, they may also raise wages. Also, it takes many years for the individuals who did not meet these requirements to leave the occupation or retire, and as a result, the educational quality of the new entrants is higher, and they dominate the current members of the occupation only after a substantial period of time. Moreover, the longer the occupation is licensed, the 
greater the ability of the members of the occupation to lobby the legislature and licensing boards to ratchet up requirements for entry within the occupation for those who might enter from unregulated states or occupations. For example, accountants increased the years of university schooling from four to five years in the 1990s in order to attain a Certified Public Accountant (CPA) license (Carpenter and Stephenson, 2006). In addition, physical therapists raised their education requirements from a bachelor's degree in the 1990s to a doctor of physical therapy license by 2016 through 2018 (Cai and Kleiner, 2016). In both cases, the national professional association promoted these enhanced or ratcheted-up requirements through the state boards of licensing or the state legislature. Although the policies may have enhanced the educational quality of the new workers, they could have also reduced access to the occupation by practitioners and consumers and limited the supply of labor to the occupation.

\section{A Licensing Model with Duration}

The model uses a framework in which the work of one occupation or individual cannot legally be done without the inputs of the other occupation. The focus of the model serves as a basis to inform and develop hypotheses about the empirical work, rather than as a fully specified general equilibrium model of production of services under regulation. The model uses a modified standard production function:

$$
\begin{aligned}
& Q_{t}^{L}=f(P(z), K)_{\mathrm{t}} \\
& Q_{t}^{U L}=f(P(z), N(z), K)_{\mathrm{t}},
\end{aligned}
$$

where $Q_{t}^{L}$ is the output produced by the licensed practitioner over time t, which we will refer to as "high-skilled services." $Q_{t}^{U L}$ is the output produced by the unlicensed worker (UL) over time t, which we will refer to as "low-skilled services.” $P(z)$ represents the licensed worker's labor, recognizing that output relies on their decision of personal input, and $N(\mathrm{z})$ represents the UL's 
labor, recognizing that output relies on the worker's decision of personal input. The variable $K$ represents the quantities of capital inputs used in a service production function (Reinhardt, 1972).

By law, however, the technology needed for ULs to produce $Q_{t}^{U L}$ is tied to supervision of entry by the licensed practitioner. Nevertheless, within a profit function, the UL's wage is tied to the decisions of the licensed practitioner to add the labor input and technology mix to the highskilled provider, $Q_{t}^{L}$. Regulation acts like a shifter of both the supply and demand curves with long time lags for full implementation over time $t$ because of grandfathering and the ratcheting up of skills for regulated practitioners. In the model, time is the proxy for grandfathering licensed workers and capturing the work of unregulated or lesser regulated practitioners. For example, a licensed engineer or architect can restrict the work of an unlicensed interior designer, reducing earnings, hours worked, or the number of workers who may choose that occupation over time (Kleiner, 2013). Regulated practitioners, who are generally in control of the production of these services, can allocate relatively low-skilled work to unlicensed workers while taking on higherskilled and value-added services for themselves and thus increasing their hours worked and earnings, but still restricting the number of workers who may enter the occupation. These central theoretical issues raised in these models are empirical questions that the rest of the paper examines.

\section{The Rationale for Grandfathering and Ratcheting}

In the labor market, the process of older, lesser trained workers leaving the workforce or moving to other occupations and newer workers with higher entry requirements entering the field takes many years or decades as the process works its way through the labor market, resulting in potentially higher wages. An illustration of the process over three periods is shown in Appendix Figure 1. The figure shows the evolution of grandfathered participants over time and how they 
diminish by leaving the occupation, through occupational mobility, retirement, or death. By the end of the period, only individuals who have gone through the licensing process are in the occupation. However, the process may limit the supply of labor in the long run by increasing entry and mobility requirements, and may allow those licensed in the occupation to gain economic benefits by limiting employment growth. In addition, occupations could also ratchet up the requirements for already licensed occupations. Therefore, licensing duration—-the time from the implementation of occupational licensing legislation—may matter. It may take years for the full effects of occupational licensing to be realized in the labor market, and for the analyst to observe these changes on wages, hours, and employment. A similar effect of regulation would occur when the occupation ratchets up the requirements for entry, such as the increases in education that occurred in accounting and physical therapy.

A further implication of the role of time for occupational licensing is that it captures the work of unregulated workers and tasks as exemplified in the North Carolina State Board of Dental Examiners v. Federal Trade Commission Supreme Court case (2015). Moreover, legal cases involving the Institute for Justice challenged cosmetologists capturing the work of hair braiding for their occupation. In addition, veterinarians have tried to legally capture the work of farmhands who do teeth filing for horses, suggesting that only trained veterinarians can do these tasks for farm animals. In all of these cases, the number of hours provided in the regulated occupations would grow as unlicensed workers declined and as the tasks were legally mandated by regulated workers, as presented in our theory overview.

The Empirical Model

We gathered statutory information for each occupation by year for each state that passed a licensure law from several different legal data sources. In order to calculate the duration of 
licensure for all states, we used a couple of different resources. Our major source of data used a Council of State Governments (1952) report to obtain information by year for each state listing their first licensing legislation for the major universally licensed occupations in our analysis. From this source alone, we were able to obtain 60 percent of the required statutory data for the thirteen universally licensed occupations. We also used the LexisNexis legal resource database to obtain the remaining statutory information. ${ }^{4}$

In order to develop a model with a sufficient time line to analyze how duration may influence labor market outcomes, we use all available data from the census and the American Community Survey (ACS) for a 75-year time period from 1940 to 2015 (Meyer and Osborne, 2005). We begin with 1940 since that was the first year wage data was added to the census. We include in our sample individuals who worked in 13 major universally licensed occupations that had more than 152 million workers over time, and which represented more than 10 percent of the U.S. workforce and about 60 percent of all individuals in universally licensed occupations. The sample includes both blue and white-collar occupations and ones that are high, middle, and low income. We limit the analysis to those 13 universally licensed occupations that have sufficient number of state and year observations in the census and were licensed in all states by 2015, the end of our period of analysis.

Figure 1 presents a timeline of state licensures for all occupations under analysis. The sample includes individuals who were either in one of the major universally licensed occupations when it became regulated or in one of the unlicensed occupations during the period. Our analysis

\footnotetext{
${ }^{4}$ For the additional remaining information on attorneys for 19 states, we contacted the Supreme Court library and Board of Examiners. We managed to obtain responses for 7 states: Arkansas, Delaware, Illinois, Indiana, Maryland, Michigan, and Minnesota. We replaced the average duration with missing values on attorneys for 12 states: Connecticut, Georgia, Missouri, Montana, Nebraska, Nevada, New Hampshire, New Jersey, New Mexico, South Carolina, Utah, and West Virginia, and we denoted with dummy variables in our statistical analysis for completeness (Little and Rubin, 1987).
} 
is limited because we can only include individuals who are covered by licensing statutes, but some may not have attained a license (Gittleman and Kleiner, 2016). Also, we cannot cover the same individuals over their careers as we can with smaller data sets such as the National Longitudinal Survey of Youth (NLSY). However, we define the appropriate treatment groups and varied control groups as described in Table 1. We first define individuals who worked in 13 major licensed occupations as a treatment group, and individuals in occupations that were never licensed throughout the period of analysis as the control group. As a robustness check, we compare the licensed workers to workers in the 13 universally licensed occupations before they were covered by the regulations.

Next, we include standard human capital variables from the census and for more recent years from the ACS, such as gender, age, education, marital status, and potential experience. In order to generate a reliable sample for our analysis, we dropped those individuals whose education is "below 12th grade without a diploma" for dentists, lawyers, accountants, and pharmacists. Also, we dropped those individual whose education level was "below high school diploma” for nurses. For barbers, we screened for those with at most a high school diploma. In addition, individuals older than 65 or younger than 23 and those with years of potential experience below zero were also deleted. ${ }^{5}$

In addition, hourly real earnings were determined by dividing the annual earnings including profits and dividends from work, by annual hours worked, adjusted by the 2014 consumer price index (CPI). Annual hours worked were calculated by multiplying the usual working hours by the number of weeks for the past 12 months. We restrict our sample to fulltime workers by eliminating those individuals who worked less than 30 hours a week and less

\footnotetext{
${ }^{5}$ We also used individuals with graduate school education for dentists, lawyers, and physicians, and the results were similar. These estimates are available from the authors.
} 
than 48 weeks a year. Also, in addition to these restrictions, the original sample was trimmed by excluding individuals with real hourly wages below the federal minimum wage level in that year and real hourly wages above $\$ 450$. The resulting sample consists of 840 million observations from 1940 to 2015 using the census and the ACS sample. ${ }^{6}$ In Table 2 we show the means and standard deviations of the individuals in the 13 universally licensed occupations with different licensure statute conditions, and individuals in never licensed occupations ${ }^{7}$ in our sample with wage data normalized by the 2014 CPI. ${ }^{8}$ In addition, we show in Table 3 descriptive statistics for each licensed and unlicensed worker in the occupations that changed their licensing status during the period of our analysis.

\section{Implementing Descriptive and Causal Estimates}

The following sections present both descriptive and causal estimates of our empirical models, initially by using a kernel estimation approach for a descriptive approach and then by using a difference-in-differences causal model that takes into account the different times that each of the occupations in our model initially became licensed in each of the 50 U.S. states over the time period of the analysis.

\section{Nonparametric Kernel Estimation}

\footnotetext{
${ }^{6}$ We show the number of observations by year in Appendix Table 1.

${ }^{7}$ We manually determine whether each occupation was ever licensed by verifying licensing status through the variable occ1990. For the 1940 census data which lacks the occ1990 variable, we made a crosswalk between occ1990 and occ1950. Data are weighted using population weights.

${ }^{8}$ As more descriptive information about the data, Appendix Table 2 shows the summary statistics of hourly wages and duration in licensed occupations split by year and regulation status. In addition, we show in Appendix Table 4 descriptive statistics for workers in the universally licensed occupations split by median duration. Appendix Table 3 shows the number of observations split by median duration and year. In Appendix Table 5 we also include summary statistics of hourly wages and duration in licensed occupations split by median duration and year.
} 
In order to provide basic descriptive data for more recent and older licensed occupations, we used a nonparametric kernel estimation procedure. The estimates for the effects of occupational licensing duration on wages using the kernel estimation procedure are shown in Figure $2 .{ }^{9}$ The estimates are a form of data smoothing. We visually show whether the longer duration of licensing exhibits wider variance in the earnings distribution.

We present the wage distribution changes after licensing legislation is enacted. The solid line represents the wage distribution for unlicensed workers in occupations that were either in one of the major universally licensed occupations when it became regulated or in one of the unlicensed occupations during the period. In the figure we also show the effect of licensing duration on the wage distributions for various time periods. The dashed line is the distribution for licensed workers with a licensing duration of less than 10 years, the dotted line is the distribution for licensed workers with a licensing duration of 11-30 years, the dash-dot line is the distribution for licensed workers with a licensing duration of 31-50 years, and the dash-dot-dot line is the distribution for licensed workers with a licensing duration of more than 50 years. Our nonparametric kernel estimation results show that the wage distributions shift more to the right the longer an occupation has been licensed, suggesting that it takes at least 30 years to fully realize the economic effects of occupational licensing on wage determination. The long time period for the full effect may reflect both the increased demand for the licensed service, the ability to more fully limit supply, and the ability to ratchet up the requirements to attain a license.

\section{Empirically Modeling Duration Effects}

\footnotetext{
${ }^{9}$ The kernel estimation procedure develops and uses an autoregressive approach to predict observed outcomes and is a theoretical method to provide basic forecasts of observed phenomena.
} 
In order to more fully empirically model the influence of occupational licensing on wage determination, hours worked, and participation in the labor market, we use a basic difference-indifferences approach. Since states implemented their licensing statutes at different times, we are able to develop an estimate of causal inference for the influence of duration on labor market outcomes. We would expect the relationship to initially move slowly as newer licensed workers enter and fewer grandfathered workers continue to work in the occupation. When grandfathered workers retire or leave the occupation, wages would likely increase more rapidly. Furthermore, wages would likely increase when workers' representatives are more fully in control of the supply of labor by ratcheting up requirements.

To causally link occupational licensing and labor market outcomes, we employ a difference-in-differences (DID) strategy using data on changes to state licensing requirements for the 13 universally licensed occupations in our sample. Such changes affect the ability of individuals to work in a licensed occupation in a particular state without needing to fulfill additional regulatory requirements. For estimation purposes, our model takes the following form:

$$
Y_{i s t}=\alpha+\delta \text { Duration }_{\text {ist }}+X_{i t} \beta+\tau_{k}+\eta_{s}+\theta_{t}+\varepsilon_{i s t}
$$

where $Y_{i s t}$ is the measure of $\log$ hourly wage or annual hours worked of individual $i$ in state $s$ in census year t. Duration $_{\text {ist }}$ is duration of the initial occupational licensing statute. We use two definitions of this key variable to estimate linear and nonlinear duration effects: 1) years from the start of state occupational licensing statute, ${ }^{10} 2$ ) the eight dummies for duration to examine the nonlinear duration effect: 0-3 years, 4-10 years, 11-20 years, 21-30 years, 31-40 years, 41-50 years, 51-100 years, and greater than or equal to 101 years. For example, the duration dummy for

\footnotetext{
${ }^{10}$ Since we allow for a one-year lag to ensure the licensing statute was already enacted by the time observation is measured, and both earnings and hours data are based on the previous calendar year, years from the start of state occupational licensing statute are calculated as follows:

Duration $_{\text {ist }}=\left(\right.$ Year of the Data $\left.\mathrm{it}_{\mathrm{it}}-1\right)-\left(\right.$ Year when licensing statute enacted $\left.\mathrm{ist}_{\mathrm{ist}}+1\right)$
} 
11-20 equals 1 , and the remaining duration dummies equal 0 for individuals in occupations that were licensed for 14 years in 2015. The variable $X_{i t}$ is individual characteristics (years of education, gender, race, potential experience, potential experience squared, and marital status), $\tau_{k}$ includes the two- or three-digit 2010 Standard Occupational Classification (SOC) fixed effects, $\eta_{s}$ includes state fixed effects, and $\theta_{t}$ includes year fixed effects. The variable of interest in this regression is $\delta(\mathrm{s})$, the coefficient(s) on the licensing duration variable. We can interpret $\delta$ as the DID estimate(s) of the effect of occupational licensing on log hourly wage or annual hours worked relative to individuals in occupations that are unlicensed throughout our period of analysis:

$$
Y_{i s t}=\alpha+\boldsymbol{\delta} \text { Duration }_{i s t}+X_{i t} \beta+\eta_{s}+\theta_{t}+\varepsilon_{i s t}
$$

As an additional sensitivity check, we limit the analysis to the major universally licensed occupations and estimate the model in equation (4). $\delta$ is the DID estimate of the licensing duration effect of the universally licensed occupations relative to unlicensed occupations in the universally licensed occupations prior to states passing licensing statutes. The other variables have the same definitions as in equation (3).

$$
Y_{i s t}=\alpha+\delta \text { Duration }_{i s t}+X_{i t} \beta+\gamma \text { Income }_{i s t}+\eta_{s}+\alpha_{t}+\varepsilon_{i s t}
$$

In equation (5) we show our model of licensed worker participation in the workforce. The variable $Y_{i s t}$ indicates whether person $i$ works in a major universally licensed occupation in state $\mathrm{s}$ in year $\mathrm{t}$, and Income $_{\text {ist }}$ is per capita mean income in state $s$ in year $t$. The other variables have the same definitions as in equation (3). We use the DID model by exploiting changes in state licensing laws and requirements over time in each of the tables presented in the rest of the paper. 
Our sources of identification are the changers in states that adopted occupational licensing laws over time relative to the non-adopters, individuals who were licensed in the same occupation in comparison to those who did not achieve licensure coverage, and any individual who was licensed relative to those who were not licensed. In order to focus only on changers during the period of analysis, we develop separate estimates for occupations that were licensed during the period 1940-2015. In order to focus on changers in licensing, we also examine by discrete time periods the influence of becoming a licensed occupation on the participation rate in the occupation (Law and Marks, 2013). However, we also present estimates of all 13 occupations in our sample, many of which were initially regulated prior to $1940 .{ }^{11}$ Moreover, since we do not assume a linear relationship between licensing adoption and its labor market effects, we present nonlinear estimates in our tables.

In Table 4 we show the influence of duration on wages using clustered standard errors at the state-occupation level. We show both linear and nonlinear specifications in the table. In addition, we show in panel A estimates using all the occupations in our sample. In panel B, we show estimates for only those occupations that changed their licensing status over the period of our analysis. In columns (4) and (6), we show the influence of the duration on wage determination with 3-digit occupation controls as a benchmark for our other specifications. The estimates in column (6) show that wage effects increase by 3 percent the first 3 years after adoption, and then wage effects increase gradually to 20 percent for those individuals in occupations that have been licensed for more than 100 years. In column (4), the estimates suggest that for every 10 years that an occupation is licensed, wages increase by a statistically significant 2 percent. Moreover, in column (2), we see that becoming licensed raises earnings by

\footnotetext{
${ }^{11}$ Occupation codes for barbers and cosmetologists are first identified in 1960, and therefore we include barbers and cosmetologists after 1960 in our sample.
} 
almost 8 percent, which is at the lower range of estimates in much of the empirical literature on the effects of licensing on wage determination (Kleiner and Krueger, 2010, Kleiner and Krueger, 2013, Gittleman, Klee and Kleiner, forthcoming).

As an additional sensitivity check, we present in columns (7), (8), and (9) the licensing duration effects on hourly wage relative to hourly wage of unlicensed workers in the 13 universally licensed occupations prior to a state passing a licensing statute. The estimate in column (8) suggests that for every 10 years that an occupation is licensed, wages increase by a statistically significant 5 percent relative to the hourly wage of unlicensed workers in the 13 universally licensed occupations prior to the state passing a licensing statute. In column (9), estimates show that hourly wages increase rapidly after 20 years from the implementation of the licensing statutes, suggesting nonlinear duration effects of this form of regulation on hourly wages.

As a robustness test of our estimates across various specifications or groups of occupations, we found relatively small differences of the wage effects over time across the specifications between older regulated occupations and those who were licensed more recently. As a further test of the strength of our findings, we also utilized the coarsened exact matching method in Iacus et al. (2012) with a DID methodology in order to remove the selection bias caused by endogenous selection into the occupations. Specifically, we perform coarsened exact matching on potential experience and marital status, and perform exact matching on race and gender and found that the results are consistent and robust to those presented in Tables 4 and $5 .{ }^{12}$

In Table 5 we present estimates of the influence of duration of occupational licensing on hours worked per year using clustered standard errors at the state-occupation level. We expect

\footnotetext{
${ }^{12}$ Difference in differences estimates combined with Coarsened Exact Matching are shown in Appendix Table 10 and we find consistent nonlinear duration effects on hourly wage and hours worked per year. In addition, the detailed matching summaries are shown in Appendix Tables 8 and 9.
} 
that if an occupation is able to restrict entry and the demand for services in the occupation is constant or rising, then the incumbent workers will work more hours. Moreover, if the substitution effect is greater than the income effect and wages grow through occupational licensing, then we anticipate that workers in the regulated occupation will have an incentive to work more hours.

Using an approach similar to the one shown in Table 4, in Table 5 we begin by estimating the influence of duration with 3-digit occupation controls and linear and nonlinear relationships on hours worked per year. We also show estimates of the two panels for all the occupations in our sample and the ones that experienced changes, and find the results consistent across different groups and specifications. We show in panel A estimates using all the occupations in our sample. We find consistent nonlinear duration effects on hours worked per year using two different control groups. In column (6), we find statistically insignificant licensing effects for the first 3 years from the start of the licensing statute, but hours worked per year start to increase rapidly after 4 years from the introduction of licensing statutes. Licensed workers in occupations that have been licensed for 11-20 years work an extra 78 hours per year compared to never licensed workers. After 40 years from licensing enactment, we find insignificant licensing effects on hours per year. Also, we find in column (2) that becoming licensed is associated with an extra 36 hours worked per year relative to hours worked per year of those never licensed workers.

As a further sensitivity test, in columns (7), (8), and (9) we again limit the sample to the 13 universally licensed occupations and find the nonlinear positive duration effects on hours relative to unlicensed workers in the 13 universally licensed occupations prior to their state passing licensing statutes. 
In panel B, we show the influence of becoming licensed using the occupations that were regulated during the period of analysis. In column (2) in panel B, the estimates of increasing the hours worked due to becoming licensed is more than 36 hours per year for those who were licensed more recently relative to hours worked per year of never licensed workers. Also, the estimates in columns (6) and (9) show the nonlinear duration effects on hours worked per year across two different comparison groups, suggesting consistent results relative to those in panel A. ${ }^{13}$ The resulting increase in hours worked per year could be due to the substitution effect of wage increases dominating the income effect for the occupations evaluated in our sample. Again, we show the influence of becoming licensed using the occupations that were regulated during the period of analysis and those who were licensed during earlier periods.

To further examine the influence of occupational licensing in the labor market, we also provide basic approximations of the potential rents that occupational licensing offers to individuals who are grandfathered to show the potential incentives for these individuals to promote this type of regulation. To develop these estimates, we use those individuals whose expected tenure in an occupation occurred during the period that the occupation initially became licensed. To illustrate, if an occupational therapist had 10 years of experience and licensing occurred after she had been in the occupation for 5 years, then that person would be considered grandfathered. In this example, individuals with tenure less than 5 years would be considered to have entered the occupation after licensing and would be a new entrant who started after the initial regulation of the occupation. In Table 6, we show descriptive statistics for grandfathered

\footnotetext{
${ }^{13}$ As an additional robustness check, we implemented a two-stage procedure that uses the state as the unit of observation rather than individual characteristics (Hanushek, 1974; Amemiya, 1978; Conley and Taber, 2011). These results are available from the authors.
} 
workers and find that about 10 percent of individuals in the 13 universally licensed occupations are grandfathered over the period we examine in our analysis.

In Tables 7 and 8, we show the DID estimates of influence of grandfathering on labor market outcomes. We again show the influence of grandfathering using the occupations that were regulated during the period of analysis, and those who were licensed during earlier periods. The results in Table 7 show that individuals who are grandfathered gained 0.3-0.7 percent per year in earnings, and their overall earnings are about 4 percent higher than their unlicensed control groups. In terms of the grandfathering effects on hours worked per year, estimates in Table 8 show that individuals who are grandfathered work 13-47 more hours than their unlicensed control groups. We also find that duration is positively and nonlinearly associated with hourly wage and hours worked per year. ${ }^{14}$

In Table 9 we show the earnings effect of grandfathering relative to new entrants into the occupation. In columns (3) and (4), we use ACS data from 2001 to 2015 to provide analysis of grandfathered workers in occupations in states that recently enacted licensing statutes. In this case, new entrants make about 26.9 percent more than grandfathered workers. However, using Oaxaca decomposition analysis, human capital differences widen the wage gap to 28.4 percent because new entrants require substantially higher human capital to obtain occupational licensure (Oaxaca, 1973). But we also find that the unexplained portion—or the potential rents to grandfathered workers-is able to explain about almost 2 percent in the wage gap in favor of

\footnotetext{
${ }^{14}$ As a further robustness check, we employ the coarsened exact matching method in Iacus et al. (2012) with a DID methodology in order to solve the common support problem and the selection bias problem. The matching methodology pairs each grandfathered worker with an unlicensed worker in the comparison group based on pre-treatment characteristics, so that the comparison group of workers have similar pre-treatment characteristics as the grandfathered workers with whom they are paired. Specifically, we perform coarsened exact matching on education, experience, and marital status, and perform exact matching on race and gender. The results of these estimates are shown in Appendix Table 11.
} 
grandfathered workers. Therefore, occupational licensing offers potential rents to individuals who are grandfathered into occupational licensing relative to unlicensed workers or new licensed entrants with similar observable covariates.

To the extent that an increase in hours worked could reflect a reduction in the number of practitioners, we next turn our attention to Table 10, which focuses on labor market participation of licensed workers. Perhaps one of the most speculated about yet little researched areas of occupational licensing is the role of this regulated institution on the labor supply of regulated practitioners (Law and Marks, 2013). In Table 10 we estimate the influence of the duration of an occupational license statute on labor market participation in universally licensed occupations, using different methods of categorizing the occupations in our sample. Unlike our previous analysis, we now include in our sample all individuals in the labor force in order to determine whether licensing affected participation in universally licensed occupations relative to all other occupations. In addition, we focus on the licensing effects on participation for individuals in universally licensed occupations with duration less than 65 years relative to occupations with duration greater than 65 years. Our estimates show the influence of the passage of the licensing statute by 3-year intervals following the passage of the law. Throughout the first 30 years following the passage of the statute, occupational licensing reduces labor force participation in universally licensed occupations. Our results imply that the occupations that are most likely to be licensed were regulated in an earlier period, and ratcheting up the requirements results in fewer workers. These declines in the number of workers in universally licensed occupations may be the reason for wages going up and the number of hours worked by practitioners increasing, as shown by Tables 4 and 5 . Consistent with the theoretical section, occupational licensing statutes can provide the basis for regulated practitioners reallocating work toward members in their own 
occupation at the expense of other workers in the occupation. An illustration of the issue is provided in the case of North Carolina State Board of Dental Examiners v. Federal Trade Commission (2015). The result of these practices could be the higher observed pay.

Any DID-type strategy relies on the assumption that treatment and control groups do not follow differential trends over time. In order to provide a further robustness check on the estimates shown in Tables 4 and 5, in Figure 3 we show the slope of the hourly wage curve before and after the change to licensure. Wages in the regulated occupations are relatively flat before the introduction of licensing, but decrease slightly immediately following regulation. Perhaps this is because of the surge in the number of people who want to enter the regulated occupation and the hours worked of those in the licensed occupation now that licensing has been introduced and lower-skilled grandfathered practitioners can continue to work, but the regulations have little bite initially. After the start of initial regulation, hourly wages increase as the duration of licensing grows, also perhaps because of workers who were grandfathered, leaving the occupation and the ability of the representatives for the occupations to ratchet up the legal requirements for entry. The statistically significant difference in slopes of the wage lines before and after the change to licensure presented in Figure 3, along with the similarities between the 13 universally licensed and never licensed groups shown in Tables 2 and 3, suggest that the DID approach of identification has validity for our empirical model. ${ }^{15}$

To further test the strength of our findings shown in Tables 4 and 5, we also check this assumption by including leads and lags of changing requirements. Specifically, we add indicator variables for 1-6 years before adoption, years 0-30 after adoption, and year 31 onward. Of these

\footnotetext{
${ }^{15}$ The estimates in Figure 3 show only occupations that changed regulatory status over the period we examined from 1940 to 2015. We also charted all the individual occupations in our sample, and they showed similar plots; these results are available from the authors.
} 
38 indicator variables, we note that the first 37 are equal to 1 only in the respective year, while the final variable is equal to 1 in each year following the 31st year after adoption.

Figures 4 and 5 plot estimated licensing effects on hourly wage and annual hours by including the leads and lags of changing the requirements. In panel A for each figure, we estimate the licensing effects of individuals in the universally licensed occupations relative to the labor market outcome of individuals in never licensed occupations at yearly intervals in the six years prior through the more than 30 years following the adoption of a licensing requirement. Using an approach similar to that in panel A, panel B shows the licensing effects of licensed individuals in universally licensed occupations relative to the labor market outcome of unlicensed workers in the universally licensed occupations prior to states passing licensing statutes. Overall, Figures 4 and 5 suggest that occupational licensing does affect hourly wage and annual hours worked. ${ }^{16}$

Occupations can have different market and institutional reasons for varying wage effects. For example, dentists usually control the dental licensing boards that determine job requirements for their occupation and auxiliary occupations such as hygienists and assistants. Other occupations such as occupational therapists are under the control of or are dominated by boards of physical therapy and are less able to restrict entry into their occupation. Moreover, physicians have long been licensed and have considerable market power as well as the advantage of having convinced the public and lawmakers of the potential adverse consequences of missed diagnoses and public health effects. In this way, they are able to limit entry and obtain long-run economic benefits (Ketel, et al., 2016). In Figures 6 and 7 we show estimates for a wide variety of occupations using the various control groups, each of which may have experienced different

\footnotetext{
${ }^{16}$ Similar analysis for occupations that changed their regulation status are shown in Appendix Figures 2 and 3. Each point estimate in Figures 4, 5, and Appendix Figures 2 and 3 is shown in Appendix Tables 6 and 7.
} 
economic and institutional environments on the road to becoming licensed. In each figure, panel A represents average duration effects for each occupation, and panel B represents heterogeneous licensure effects over different occupations. ${ }^{17}$ Considered together, Figures 6 and 7 suggest that wages are generally similar but that dentists, for example, have much higher wages and lower hours worked as a consequence of occupational licensing.

From a policy perspective, our estimates are consistent with the decision of the U.S. Supreme Court in holding that dentists were operating as monopolists in reallocating tasks to themselves when the North Carolina State Board of Dental Examiners outlawed the work of "teeth whiteners" (North Carolina State Board of Dental Examiners v. Federal Trade Commission, 2015). Our results suggest that occupational licensing works slowly over time as older, less skilled workers retire or move to other occupations and the state boards or legislatures that regulate the professions ratchet up the requirements for entry. Our ability to begin to document these changes shows how important labor market institutions work with deliberate speed to enhance the work and pay arrangements for their members, in contrast to policies such as the minimum wage or changes in unemployment insurance policies, whose influence is more immediate (Kleiner, 2015).

\section{Conclusions}

Since the implementation of new occupational licensing statutes takes time to fully carry out, duration of occupational statutes should matter in influencing labor market outcomes. For example, states often enact grandfather clauses that allow continuing practitioners to continue working without meeting the new requirements, or they ratchet up the requirements for entry, such as education and reciprocity agreements with other states or nations, that protect existing

\footnotetext{
${ }^{17}$ Tables for each occupation are available from the authors.
} 
workers. One implication is that new entrants must have higher regulatory standards than those already in the occupation. The process of older, less educated workers leaving and newer workers with higher entry requirements entering the occupation takes time to work its way through the labor market. Our analysis uses a model in which licensed practitioners influence the number and kinds of jobs that they and unregulated workers can do over the long run. We use data for 13 large, diverse licensed occupations covering a 75-year period to examine the labor market effects of initial licensure. Consistent with a theory of regulation, our results show that grandfathered workers' wages rise relative to unlicensed individuals' wages in our two control groups. Moreover, there are incentives for incumbents in the occupation to raise standards because they can get higher wages. However, the relative number of workers in the occupation declines somewhat. Our study should allow policy analysts and policy makers to develop and implement more informed decisions on the long-run implications of the rapidly growing labor market institution of occupational licensing. 


\section{References}

Amemiya, Takeshi. 1978. A note on a random coefficients model. International Economic Review, 19(3), 793-796.

Beck, Andrew. 2004. The Flexner Report and the standardization of American medical education. Journal of the American Medical Association, 29(17), 2139-2140.

Cai, Jing, and Morris M. Kleiner. 2016. The labor market consequences of regulating similar occupations: The licensing of occupational and physical therapists. Upjohn Institute for Employment Research Working Paper 16-259.

Carpenter, Charles, and E. Frank Stephenson. 2006. The 150-hour rule as a barrier to entering public accountancy. Journal of Labor Research, 27(1), 115-126.

Conley, Timothy G., and Christopher R. Taber. 2011. Inference with "difference in differences" with a small number of policy changes. Review of Economics and Statistics, 93(1), 113-125.

Council of State Governments. 1952. Occupational Licensing Legislation in the States. Chicago: Council of State Governments.

Department of the Treasury Office of Economic Policy, Council of Economic Advisers, and Department of Labor. 2015. Occupational Licensing: A Framework for Policymakers. https://www.whitehouse.gov/sites/default/files/docs/licensing_report_final_nonembargo.pdf.

DiNardo John, and David Lee. 2004. Economic impacts of new unionization on private sector employers: 1984-2001. Quarterly Journal of Economics, 119(4), 1383-1441.

Freeman, Richard B., and Morris M. Kleiner. 1990. The impact of new unionization on wages and working conditions. Journal of Labor Economics, 8(1) Part 2, S8-S25. 
Friedman, Milton. 1962. Capitalism and Freedom. Chicago: University of Chicago Press.

Friedman, Milton, and Simon Kuznets. 1945. Income from Independent Professional Practice. New York: National Bureau of Economic Research.

Gittleman, Maury, and Morris M. Kleiner. 2016. Wage effects of unionization and occupational licensing coverage in the United States. Industrial and Labor Relations Review, 69(1), 142-172.

Gittleman, Maury, Mark A. Klee, and Morris M. Kleiner. Analyzing the labor market outcomes of occupational licensing. Industrial Relations, forthcoming.

Hanushek, Eric A. 1974. Efficient estimators for regressing regression coefficients. American Statistician, 28(2), 66-67.

Hirsch, Barry T., and Macpherson, David A. 2013.Union membership and coverage database from the CPS. Accessed 10/30/2013 from http://www.unionstats.com/.

Hurwicz, Leonid. 1973. The design of mechanisms for resource allocation. American Economic Review, 63 (2), 1-30.

Iacus, S. M., Gary King, and Giuseppe Porro. 2012. Causal Inference Without Balance Checking: Coarsened Exact Matching. Political Analysis, 1-24.

Ketel, Nadine, Edwin Leuven, Hessel Oosterbeek, and Bas van der Klaauw. 2016. American Economic Journal: Applied Economics, 8(2), 225-254

Kleiner, Morris M. 2006. Licensing Occupations: Enhancing Quality or Restricting Competition? Kalamazoo, MI: W.E. Upjohn Institute for Employment Research.

Kleiner, Morris M. 2015. Guild-Ridden Labor Markets: The Curious Case of Occupational Licensing. Kalamazoo, MI: W.E. Upjohn Institute for Employment Research. 
Kleiner, Morris M., 2013. Stages of Occupational Regulation: Analysis of Case Studies. WE Upjohn Institute.

Kleiner, Morris M., and Alan B. Krueger. 2010. The prevalence and effects of occupational licensing. British Journal of Industrial Relations, 48(4), 676-687.

Kleiner, Morris M., and Alan B. Krueger. 2013. Analyzing the extent and influence of occupational licensing on the labor market. Journal of Labor Economics 31(2), S173-202.

Law, Marc T., and Mindy S. Marks. 2009. The effects of occupational licensing laws on minorities: Evidence from the Progressive Era.” Journal of Law and Economics 52(2), 351-366.

Law, Marc T., and Mindy S. Marks. 2013. From certification to licensure: Evidence from registered and practical nurses in the United States, 1950-1970. European Journal of Comparative Economics, 10(2), 177-198.

Lee, David S., and Alexandre Mas. 2012. Long-run impacts of unions on firms: New evidence from financial markets, 1961-1999. Quarterly Journal of Economics, 127(1), 333-378.

Little, Roderick, and Daniel Rubin, 1987. Statistical Analysis with Missing Data. New York: John Wiley.

Meyer, Peter B., and Anastasiya M. Osborne. 2005. Proposed category system for 1960-2000 census occupations. BLS Working Paper WP-383.

North Carolina State Board of Dental Examiners v. Federal Trade Commission No. 15-534, 547 U.S. 2015.

Oaxaca, Ronald., 1973. Male-female wage differentials in urban labor markets. International Economic Review, 14(3), 693-709. 
Pagliero, Mario. 2010. Licensing exam difficulty and entry salaries in the US market for lawyers. British Journal of Industrial Relations, 48(4), 726-739.

Reinhardt, Uwe. 1972. A production function for physician services. Review of Economics and Statistics, 54(February), 55-66.

Shavell, Steven. 2007. On optimal legal change, past behavior, and grandfathering. National Bureau of Economic Research Working Paper 13563.

Spence, Michael. 1973. Job market signaling. Quarterly Journal of Economics, 87(3), 355-374.

Timmons, Edward J., and Robert J. Thornton. 2010. The licensing of barbers in the USA. British Journal of Industrial Relations, 48(4), 740-757.

Timmons, Edward J., and Robert J. Thornton. 2013. Licensing one of the world's oldest professions: Massage. Journal of Law and Economics, 56(2), 371-388.

Wheelan, Charles J. 1999. Politics or public interest? An empirical examination of occupational licensure. Unpublished. Accessed October 10, 2017. http://www.worldcat.org/title/empiricalexamination-of-the-political-economy-of-occupational-licensure/oclc/40557776. 
Figure 1. Timeline of When Occupations Became Licensed

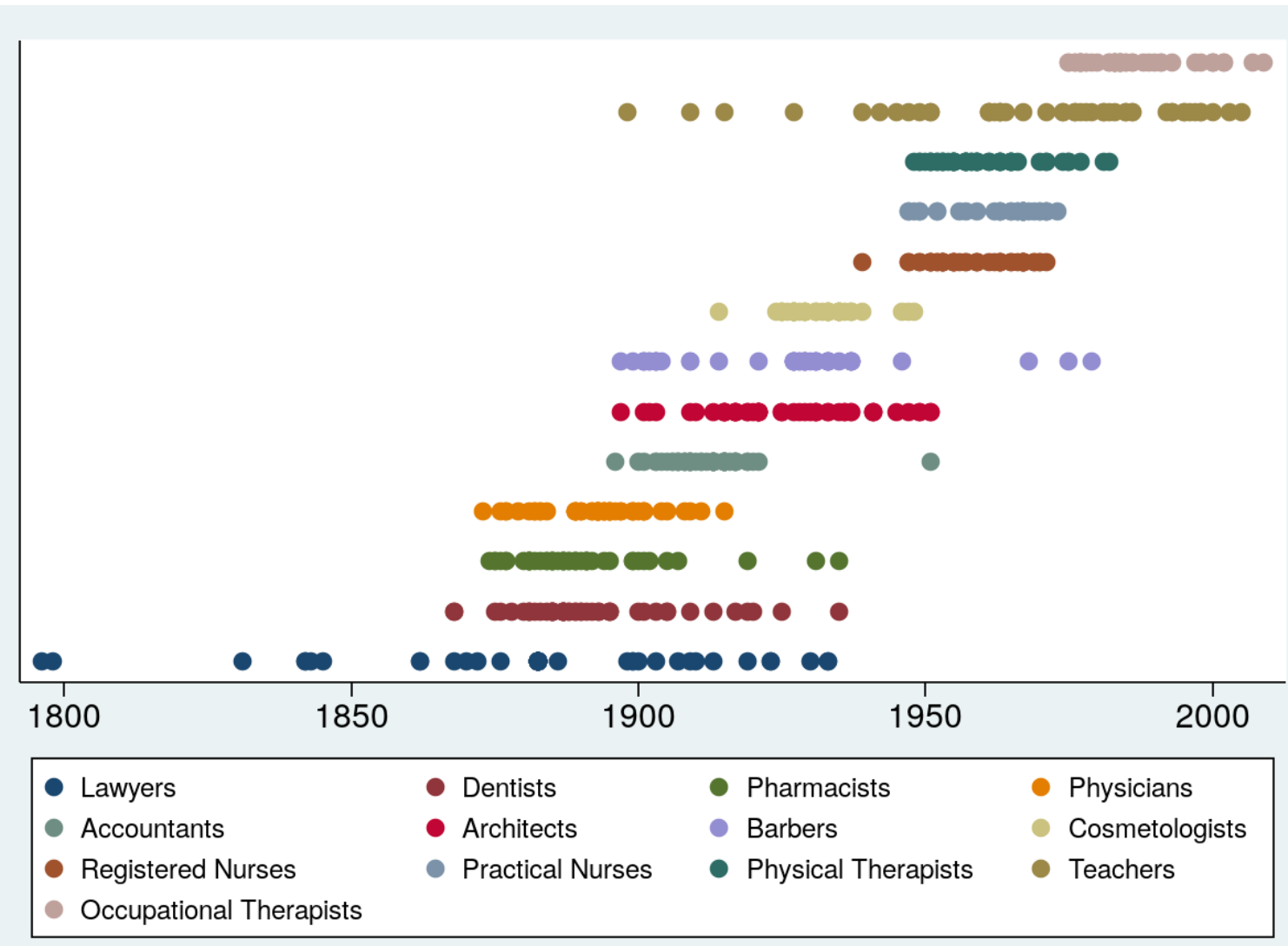

Note: Developed from the authors' examination of the initial implementation of occupational licensing using Occupational Licensing Legislation in the States (Council of State Governments, 1952) and LexisNexis legal data services. 
Figure 2. Estimated Densities of Log Hourly Wage by Licensure and Duration

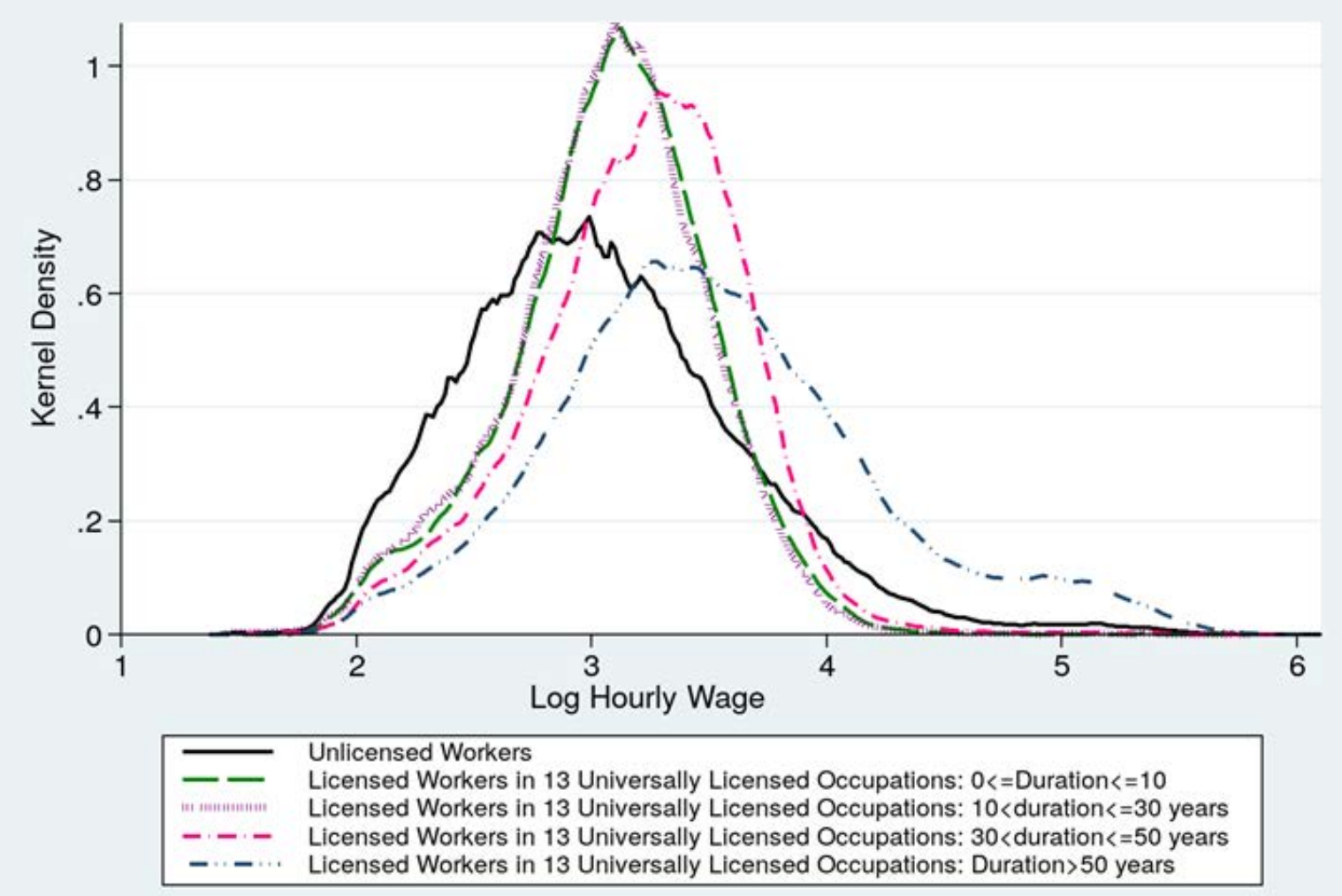

Note: The $x$-axis is the log of hourly wages, and the $y$-axis is the corresponding density. Solid black line: density for the control group of individuals either in occupations that are unlicensed throughout our period of analysis or in the 13 universally licensed occupations prior to states passing licensing statutes. Dashed green line: treatment group of licensed individuals in the 13 universally licensed occupations where states enacted licensing statutes 0-10 years ago. Dotted purple line: treatment group of individuals in the 13 universally licensed occupation for those licensed for 11 to 30 years. Dash-dotted pink line: treatment group of individuals in the 13 universally licensed occupations for those licensed for 31 to 50 years. Dash-dot-dotted blue line: treatment group of individuals in the 13 universally licensed occupation for those licensed for more than 50 years. 
Figure 3. Estimated Slopes of Hourly Wages before and after the Implementation of Licensing Statutes

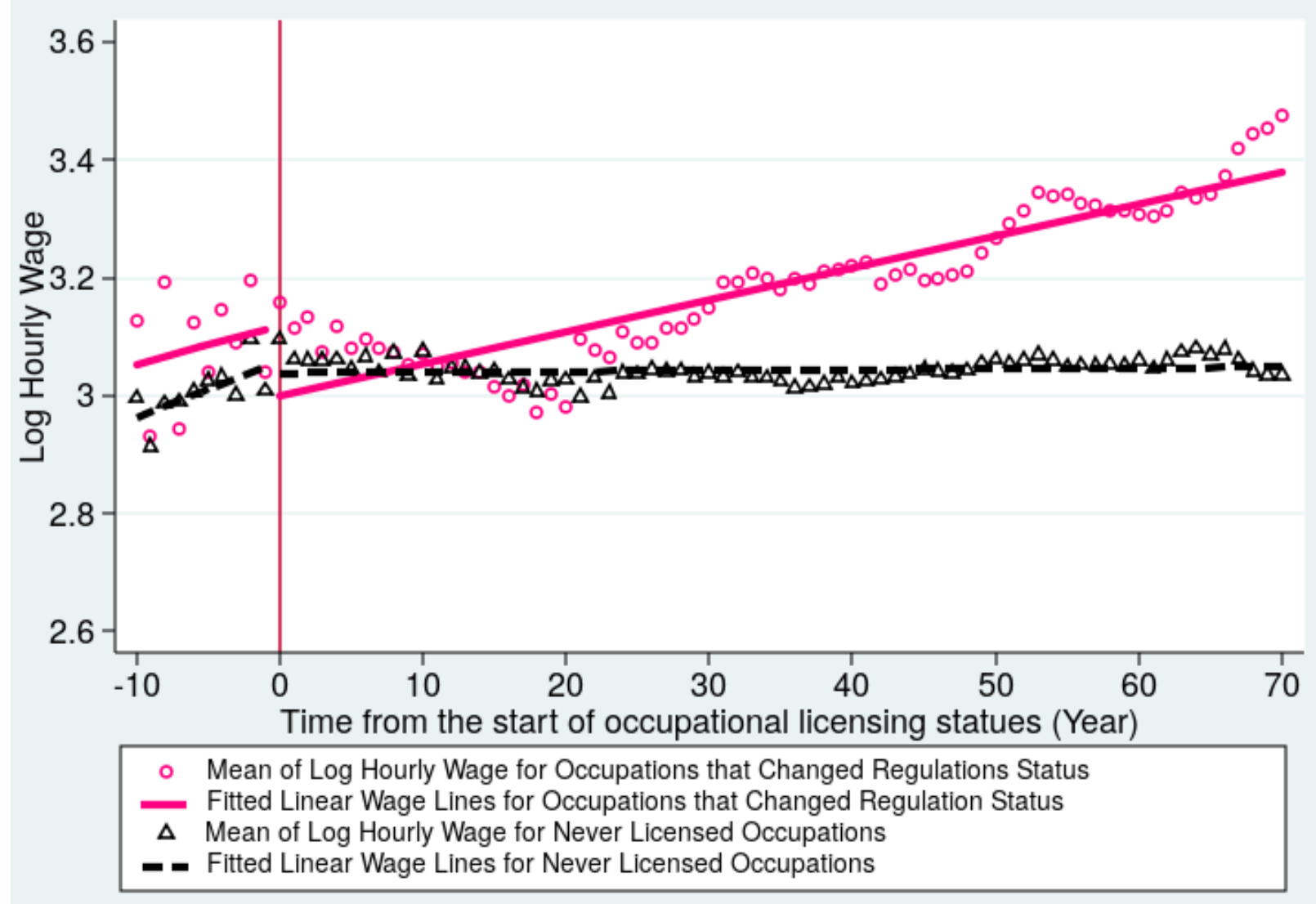

Note: Slopes of the lines are statistically different after the implementation of a licensing statute. We plot the wage lines before and after the licensing legislation for (a) occupations that changed licensing status and (b) occupations that were never licensed. For (a), we fit two linear wage lines, before and after licensing legislation, over the mean log hourly wages across duration of our 8 occupations that changed licensing status. For (b), we again fit over mean log hourly wages across duration as before, but now we consider the wages over duration of never licensed workers with respect to various years of licensure per state for occupations in (a). Specifically, for each occupation in (a), we map the state and year of first licensure information onto the never licensed workers and calculate occupational licensing durations for each wage observation. Next, we take these 8 matched copies of never licensed worker observations with different duration bases and calculate the mean of log hourly wages grouped by duration. Finally, we fit the expanded data for never licensed workers into two linear lines for the before and after licensing legislation. 
Figure 4. Estimated Licensing Effects on Log Hourly Wage before, during, and after Licensing Statutes

A. Relative to Individuals in Occupations That Are Unlicensed Throughout Our Period of Analysis

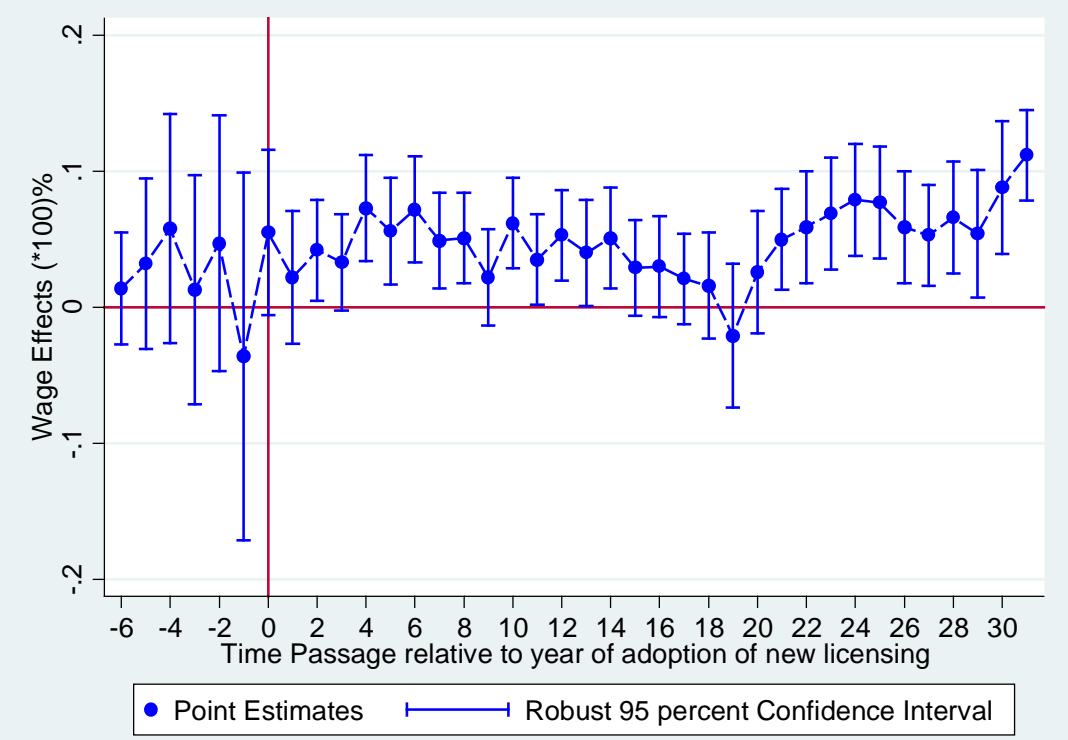

Note: Vertical bands represent \pm 1.96 times the standard error of each point estimate.

B. Relative to Individuals in Universally Licensed Occupations Prior to States Passing Licensing Statutes

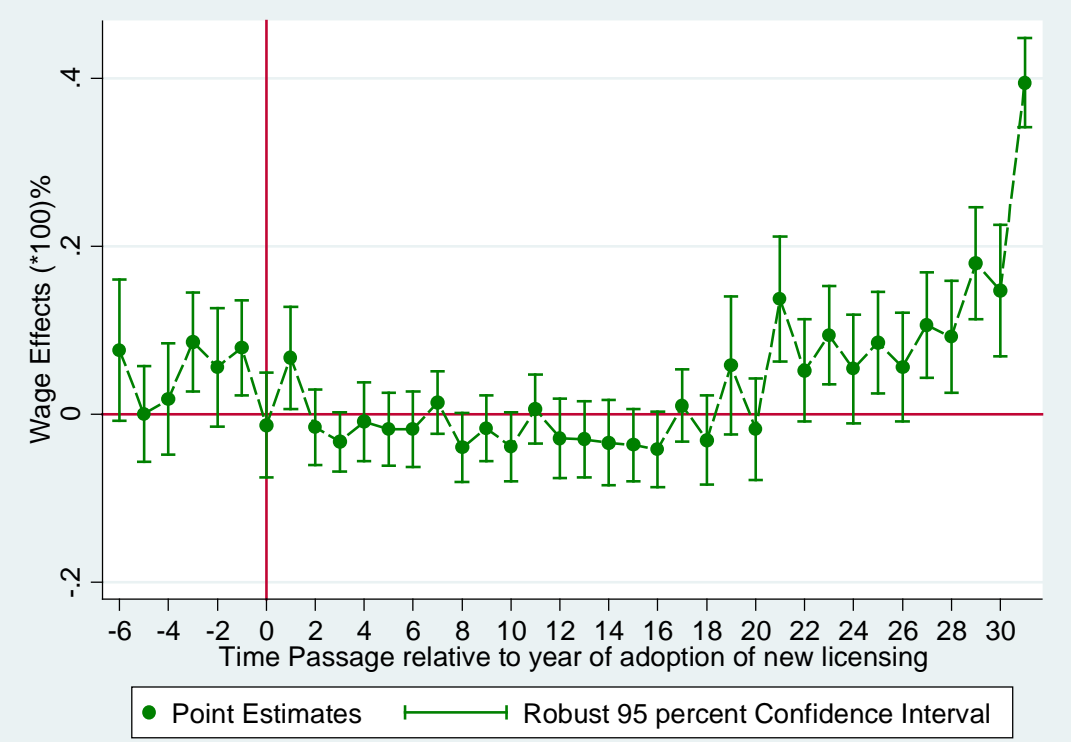

Note: Vertical bands represent \pm 1.96 times the standard error of each point estimate. 
Figure 5. Estimated Licensing Effects on Annual Hours Worked before, during, and after Licensing Legislation

A. Relative to Individuals in Occupations That Are Unlicensed Throughout Our Period of Analysis

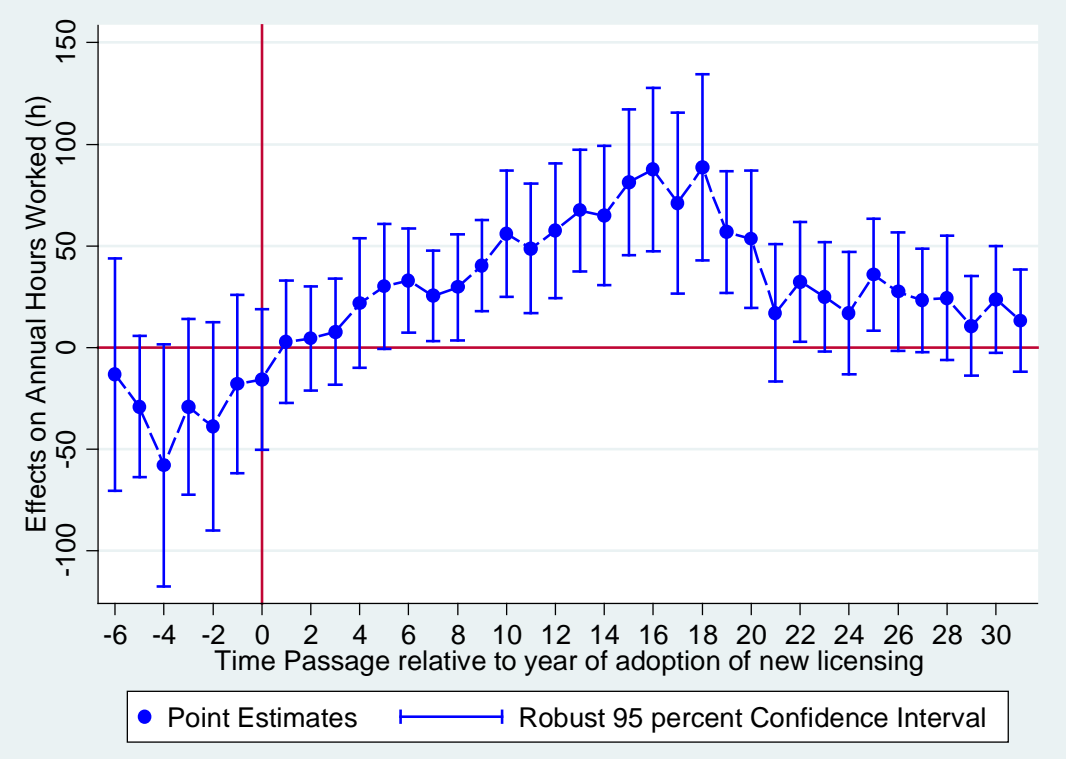

Note: Vertical bands represent \pm 1.96 times the standard error of each point estimate.

B. Relative to Individuals in Universally Licensed Occupations Prior to States Passing Licensing Statutes

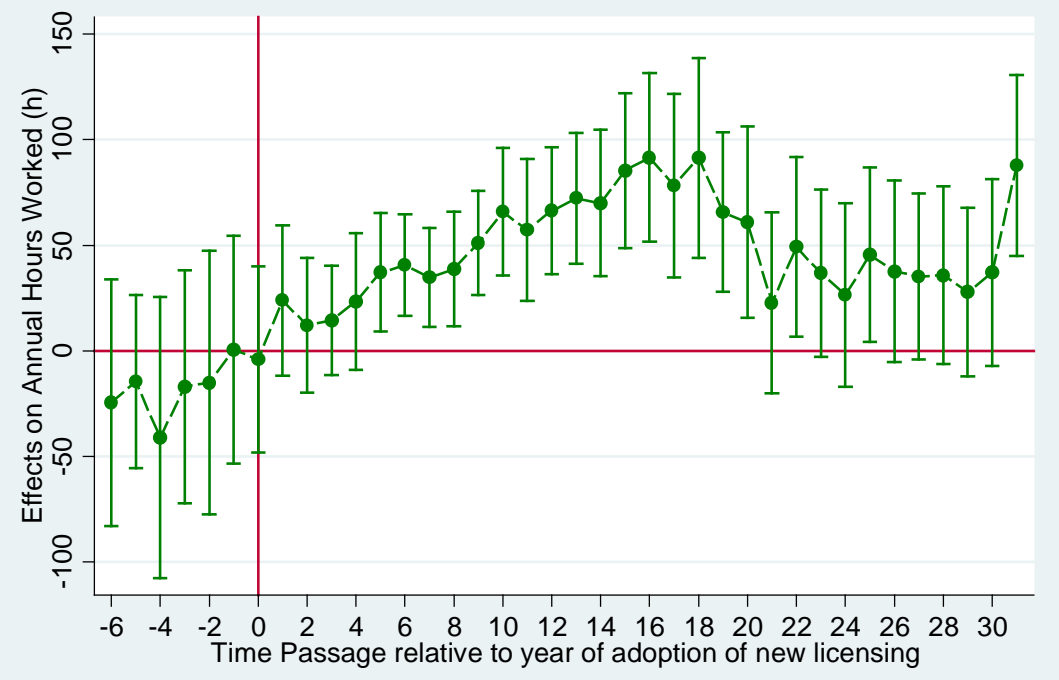

- Point Estimates $\longmapsto$ Robust 95 percent Confidence Interval

Note: Vertical bands represent \pm 1.96 times the standard error of each point estimate. 
Figure 6. Heterogeneity of the Influence of Licensing and Licensing Duration on Hourly Wage Determination

\section{A. Licensing Effects on Hourly Wage}

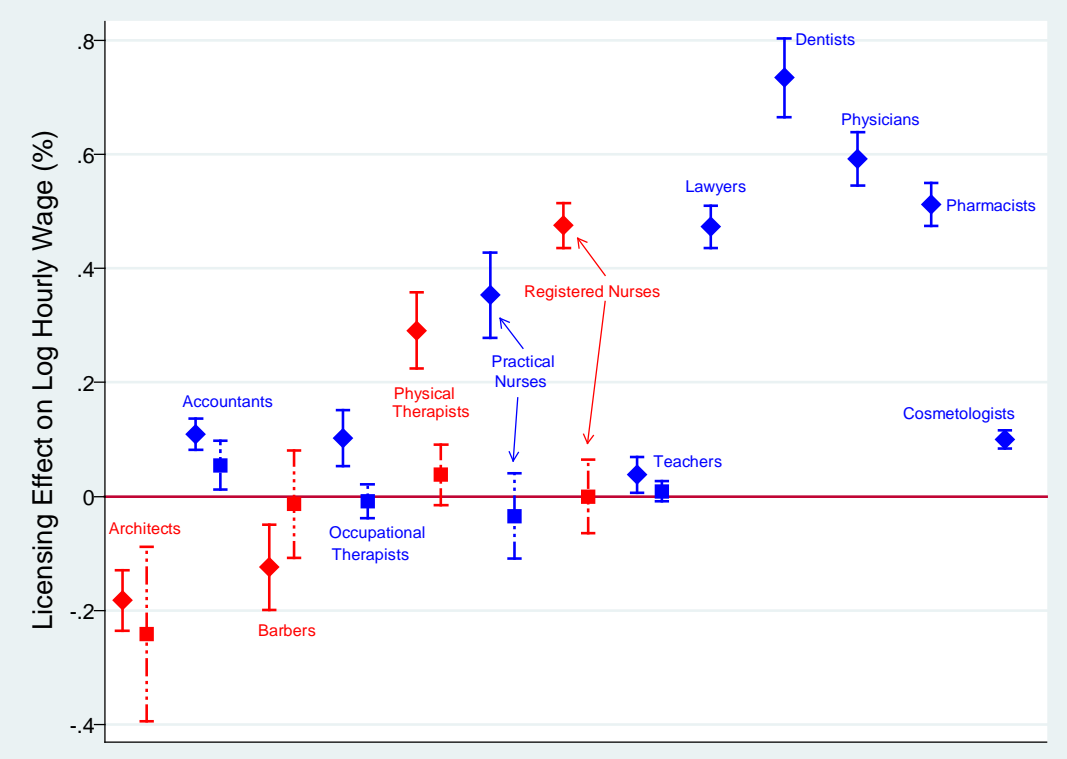

Note: Point estimate represents the licensing effect relative to hourly wage of individuals in occupations that are unlicensed throughout our period of analysis. Point estimate - represents the licensing effect relative to hourly wage of individuals in the same occupation prior to states passing licensing statutes.

\section{B. Duration Effects on Hourly Wage}

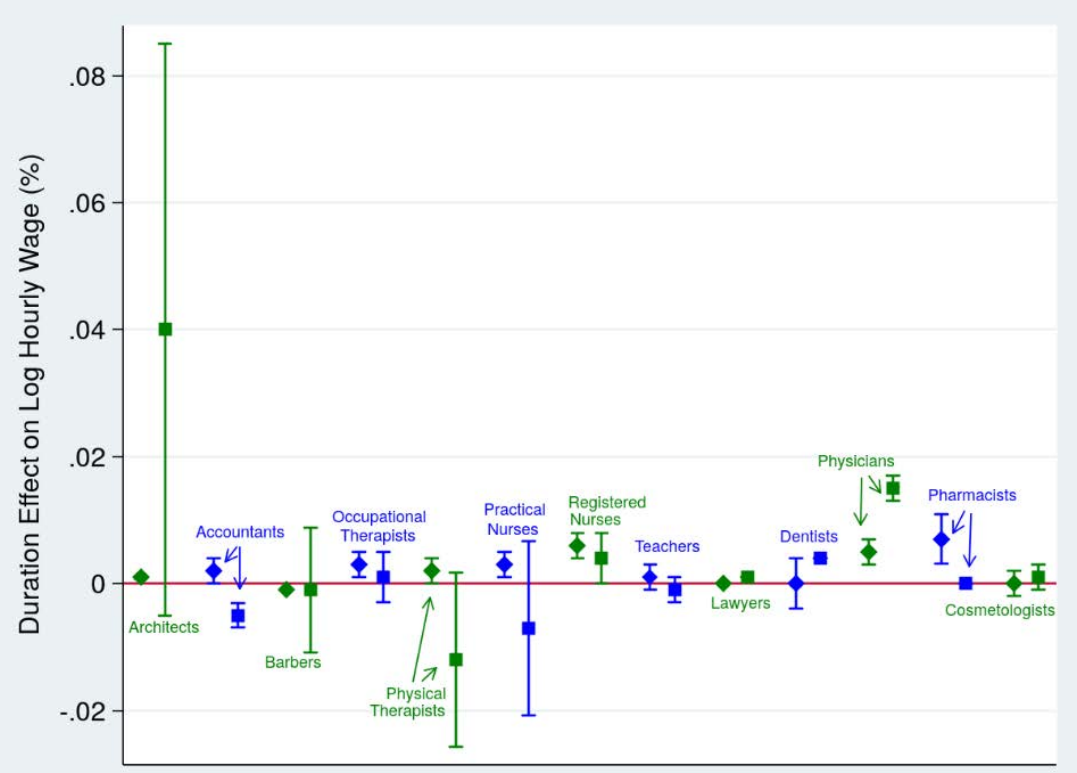

Note: Point estimate $\downarrow$ represents the licensing effect relative to hourly wage of individuals in occupations that are unlicensed throughout our period of analysis. Point estimate - represents the licensing effect relative to hourly wage of individuals in the same occupation prior to states passing licensing statutes. 
Figure 7. Heterogeneity of the Influence of Licensing and Licensing Duration on Hours Worked per Year

\section{A. Licensing Effects on Hours Worked per Year}

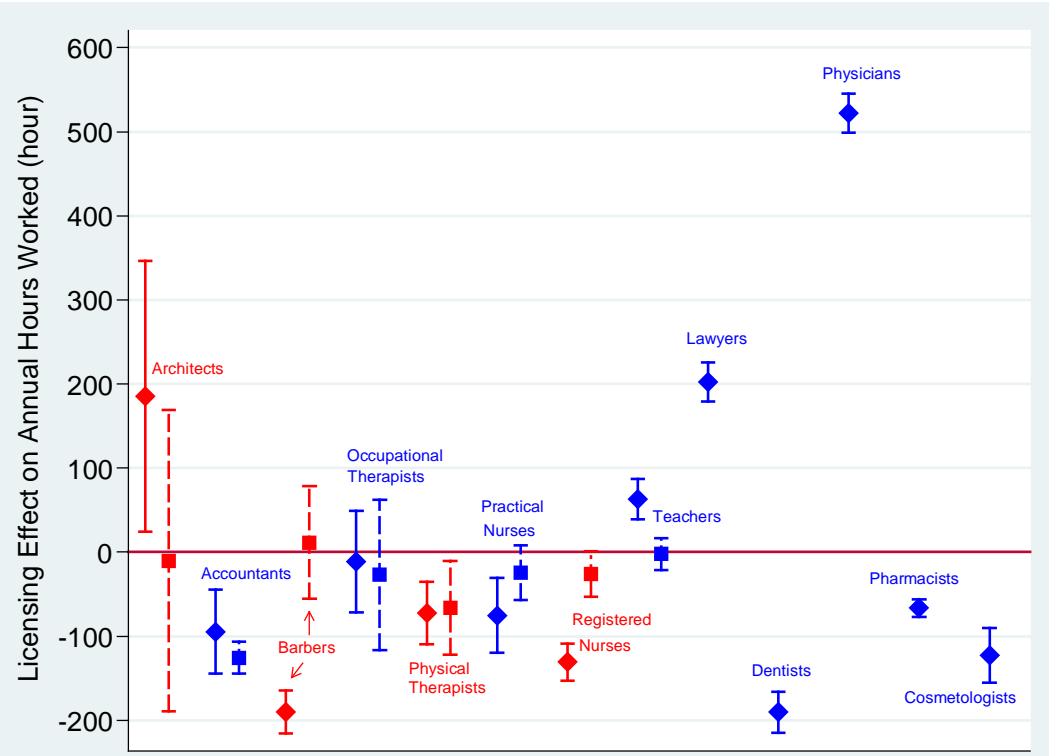

Note: Point estimate represents the licensing effect relative to hourly wage of individuals in occupations that are unlicensed throughout our period of analysis. Point estimate - represents the licensing effect relative to hourly wage of individuals in the same occupation prior to states passing licensing statutes.

\section{B. Licensing Effects on Hours Worked per Year}

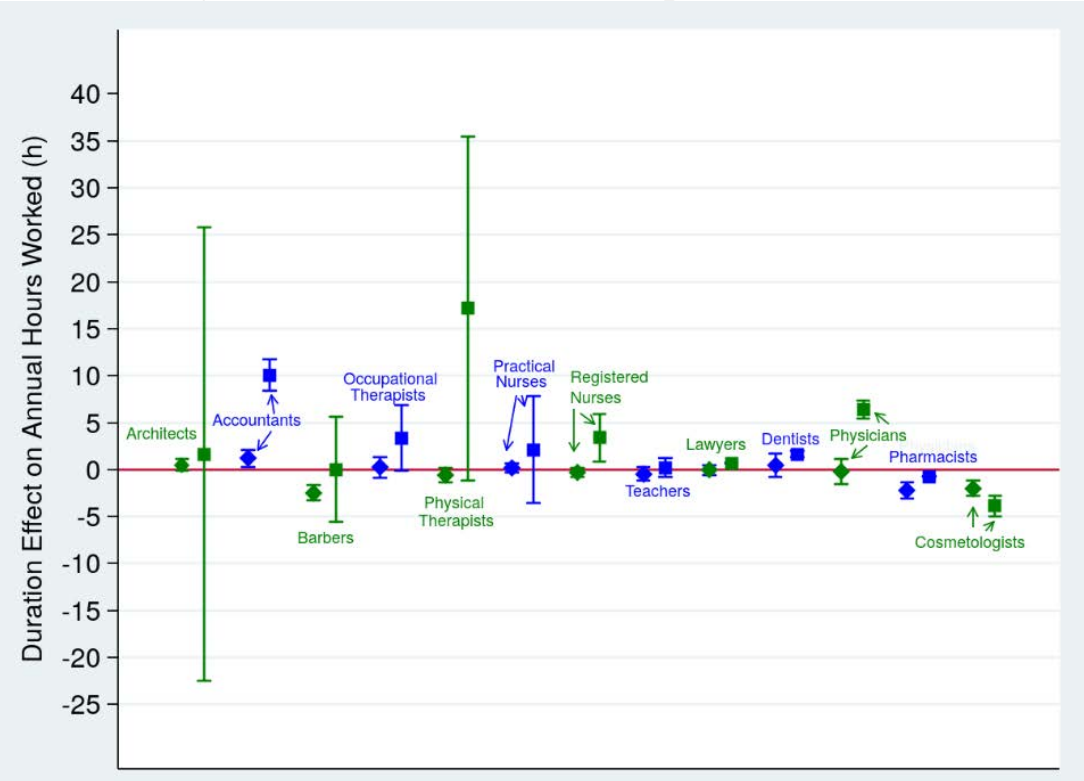

Note: Point estimate represents the licensing effect relative to hourly wage of individuals in occupations that are unlicensed throughout our period of analysis. Point estimate represents the licensing effect relative to hourly wage of individuals in the same occupation prior to states passing licensing statutes. 
Table 1. Control and Treatment Groups: Composition of Occupations

\begin{tabular}{|c|c|c|}
\hline & Treatment Group & Control Group \\
\hline Sample Construction I & $\begin{array}{l}\text { Workers in the } 13 \text { universally } \\
\text { licensed occupations between } 1940 \\
\text { and 2015: architects, accountants, } \\
\text { barbers, cosmetologists, dentists, } \\
\text { occupational therapists, physical } \\
\text { therapists, practical nurses, registered } \\
\text { nurses, pharmacists, physicians, } \\
\text { lawyers, and teachers }\end{array}$ & $\begin{array}{l}\text { Workers in occupations that were } \\
\text { never licensed during the period } \\
1940-2015\end{array}$ \\
\hline Sample Construction II & $\begin{array}{l}\text { Licensed workers in the } 13 \\
\text { universally licensed occupations } \\
\text { between } 1940 \text { and 2015: architects, } \\
\text { accountants, barbers, cosmetologists, } \\
\text { dentists, occupational therapists, } \\
\text { physical therapists, practical nurses, } \\
\text { registered nurses, pharmacists, } \\
\text { physicians, lawyers, and teachers }\end{array}$ & $\begin{array}{l}\text { Unlicensed workers in the same } \\
\text { occupations as the treatment group: } \\
\text { architects, accountants, barbers, } \\
\text { cosmetologists, dentists, occupational } \\
\text { therapists, physical therapists, } \\
\text { practical nurses, registered nurses, } \\
\text { pharmacists, physicians, lawyers, and } \\
\text { teachers prior to their becoming } \\
\text { licensed }\end{array}$ \\
\hline Sample Construction III ${ }^{1}$ & $\begin{array}{l}\text { Workers in occupations licensed by } \\
\text { the states between } 1940 \text { and 2015: } \\
\text { architects, accountants, barbers, } \\
\text { occupational therapists, physical } \\
\text { therapists, practical nurses, registered } \\
\text { nurses, and teachers }\end{array}$ & $\begin{array}{l}\text { Workers in occupations that were } \\
\text { never licensed during the period } \\
\text { 1940-2015 }\end{array}$ \\
\hline Sample Construction IV ${ }^{2}$ & $\begin{array}{l}\text { Licensed workers in occupations that } \\
\text { were licensed between } 1940 \text { and } \\
\text { 2015: architects, accountants, barbers, } \\
\text { occupational therapists, physical } \\
\text { therapists, practical nurses, registered } \\
\text { nurses, and teachers }\end{array}$ & $\begin{array}{l}\text { Unlicensed workers in the same } \\
\text { occupations as the treatment group: } \\
\text { architects, accountants, barbers, } \\
\text { occupational therapists, physical } \\
\text { therapists, practical nurses, registered } \\
\text { nurses, and teachers prior to their } \\
\text { becoming licensed }\end{array}$ \\
\hline
\end{tabular}

Note: 1. Sample construction III drops the universally licensed occupations that did not change regulation status throughout our period of analysis and compares individuals in the 8 universally licensed occupations that changed regulation status with individuals in never licensed occupations.

2. Sample construction IV drops the universally licensed occupations that did not change regulation status throughout our period of analysis and compares individuals in the 8 universally licensed occupations that changed regulation status with individuals in the 8 universally licensed occupations prior to states passing licensing statutes. 
Table 2. Means and Standard Deviation of Licensed and Unlicensed Occupations: By Regulation Status

\begin{tabular}{|c|c|c|c|}
\hline \multirow[b]{2}{*}{ VARIABLES } & \multicolumn{2}{|c|}{13 Universally Licensed Occupations } & \multirow{2}{*}{$\begin{array}{l}\text { Occupations That Are } \\
\text { Unlicensed Throughout } \\
\text { Our Period of Analysis }\end{array}$} \\
\hline & Licensed Workers & $\begin{array}{l}\text { Unlicensed Workers } \\
\text { Prior to States } \\
\text { Passing Licensing } \\
\text { Statutes }\end{array}$ & \\
\hline White & $\begin{array}{c}0.808 \\
(0.394)\end{array}$ & $\begin{array}{c}0.891 \\
(0.311)\end{array}$ & $\begin{array}{c}0.794 \\
(0.405)\end{array}$ \\
\hline Male & $\begin{array}{c}0.337 \\
(0.473)\end{array}$ & $\begin{array}{c}0.374 \\
(0.484)\end{array}$ & $\begin{array}{c}0.532 \\
(0.499)\end{array}$ \\
\hline Potential Experience & $\begin{array}{c}20.263 \\
(11.085)\end{array}$ & $\begin{array}{c}17.266 \\
(10.961)\end{array}$ & $\begin{array}{c}22.327 \\
(11.458)\end{array}$ \\
\hline Years of Education & $\begin{array}{l}16.022 \\
(1.979)\end{array}$ & $\begin{array}{l}15.896 \\
(2.127)\end{array}$ & $\begin{array}{l}13.450 \\
(2.359)\end{array}$ \\
\hline \multicolumn{4}{|l|}{ Marital Status: } \\
\hline Married & $\begin{array}{c}0.639 \\
(0.480)\end{array}$ & $\begin{array}{c}0.643 \\
(0.479)\end{array}$ & $\begin{array}{c}0.589 \\
(0.492)\end{array}$ \\
\hline Married Absent & $\begin{array}{c}0.016 \\
(0.126)\end{array}$ & $\begin{array}{c}0.019 \\
(0.137)\end{array}$ & $\begin{array}{c}0.020 \\
(0.142)\end{array}$ \\
\hline Widowed/Divorced/Separated & $\begin{array}{c}0.148 \\
(0.355)\end{array}$ & $\begin{array}{c}0.113 \\
(0.316)\end{array}$ & $\begin{array}{c}0.165 \\
(0.372)\end{array}$ \\
\hline Single/Never Married & $\begin{array}{c}0.196 \\
(0.397)\end{array}$ & $\begin{array}{c}0.225 \\
(0.418)\end{array}$ & $\begin{array}{c}0.225 \\
(0.418)\end{array}$ \\
\hline Licensure & $\begin{array}{c}1.000 \\
(0.000)\end{array}$ & $\begin{array}{c}0.000 \\
(0.000)\end{array}$ & $\begin{array}{c}0.000 \\
(0.000)\end{array}$ \\
\hline Duration & $\begin{array}{c}64.448 \\
(37.504)\end{array}$ & $\begin{array}{c}0.000 \\
(0.000)\end{array}$ & $\begin{array}{c}0.000 \\
(0.000)\end{array}$ \\
\hline $\begin{array}{l}\text { Hourly Wage } \\
\text { (2014 CPI) }\end{array}$ & $\begin{array}{c}35.977 \\
(31.744)\end{array}$ & $\begin{array}{c}22.356 \\
(11.157)\end{array}$ & $\begin{array}{c}25.792 \\
(22.683)\end{array}$ \\
\hline Weeks per Year & $\begin{array}{l}51.248 \\
(0.828)\end{array}$ & $\begin{array}{l}51.231 \\
(1.135)\end{array}$ & $\begin{array}{l}51.325 \\
(0.814)\end{array}$ \\
\hline Hours per Week & $\begin{array}{l}43.660 \\
(8.967)\end{array}$ & $\begin{array}{l}42.538 \\
(7.169)\end{array}$ & $\begin{array}{l}42.977 \\
(7.681)\end{array}$ \\
\hline Hours per Year & $\begin{array}{r}2237.563 \\
(461.322) \\
\end{array}$ & $\begin{array}{l}2179.171 \\
(369.992) \\
\end{array}$ & $\begin{array}{r}2206.053 \\
(397.182) \\
\end{array}$ \\
\hline Observations & $1,935,552$ & 61,490 & $9,243,914$ \\
\hline Weighted Observations & $150,095,251$ & $2,429,584$ & $687,525,536$ \\
\hline
\end{tabular}

Note: The 13 universally licensed occupations include architects, accountants, barbers, cosmetologists, dentists, occupational therapists, physical therapists, practical nurses, physicians, pharmacists, registered nurses, lawyers, and teachers. We manually determine whether each occupation was ever licensed by verifying licensing status through the variable occ1990. For the 1940 census data which lacks the occ1990 variable, we made a crosswalk between occ1990 and occ1950. Data are weighted using population weights. 
Table 3. Means and Standard Deviation of Licensed and Unlicensed Occupations: By Regulations Status for Those Whose Licensing Status Changed

\begin{tabular}{|c|c|c|c|c|}
\hline \multirow{3}{*}{ VARIABLES } & \multicolumn{3}{|c|}{13 Universally Licensed Occupations } & \multirow{3}{*}{$\begin{array}{l}\text { Occupations That } \\
\text { Are Unlicensed } \\
\text { Throughout Our } \\
\text { Period of Analysis }\end{array}$} \\
\hline & $\begin{array}{l}\text { Occupations that } \\
\text { Did Not Change } \\
\text { Their Regulations }\end{array}$ & \multicolumn{2}{|c|}{$\begin{array}{c}\text { Occupations that Changed Their } \\
\text { Regulation Status }\end{array}$} & \\
\hline & Licensed Workers & Licensed Workers & $\begin{array}{c}\text { Unlicensed } \\
\text { Workers Prior to } \\
\text { States Passing } \\
\text { Licensing Statutes }\end{array}$ & \\
\hline White & $\begin{array}{l}0.815 \\
(0.388)\end{array}$ & $\begin{array}{c}0.806 \\
(0.396)\end{array}$ & $\begin{array}{c}0.891 \\
(0.311)\end{array}$ & $\begin{array}{c}0.794 \\
(0.405)\end{array}$ \\
\hline Male & $\begin{array}{l}0.594 \\
(0.491)\end{array}$ & $\begin{array}{c}0.269 \\
(0.443)\end{array}$ & $\begin{array}{c}0.374 \\
(0.484)\end{array}$ & $\begin{array}{c}0.532 \\
(0.499)\end{array}$ \\
\hline Potential Experience & $\begin{array}{l}19.810 \\
(10.609)\end{array}$ & $\begin{array}{c}20.384 \\
(11.205)\end{array}$ & $\begin{array}{l}17.266 \\
(10.961)\end{array}$ & $\begin{array}{l}22.327 \\
(11.458)\end{array}$ \\
\hline Years of Education & $\begin{array}{l}17.078 \\
(2.011)\end{array}$ & $\begin{array}{l}15.741 \\
(1.874)\end{array}$ & $\begin{array}{l}15.896 \\
(2.127)\end{array}$ & $\begin{array}{l}13.450 \\
(2.359)\end{array}$ \\
\hline \multicolumn{5}{|l|}{ Marital Status: } \\
\hline Married & $\begin{array}{l}0.700 \\
(0.459)\end{array}$ & $\begin{array}{c}0.624 \\
(0.484)\end{array}$ & $\begin{array}{c}0.643 \\
(0.479)\end{array}$ & $\begin{array}{c}0.589 \\
(0.492)\end{array}$ \\
\hline Married Absent & $\begin{array}{c}0.017 \\
(0.128)\end{array}$ & $\begin{array}{c}0.016 \\
(0.126)\end{array}$ & $\begin{array}{c}0.019 \\
(0.137)\end{array}$ & $\begin{array}{c}0.020 \\
(0.142)\end{array}$ \\
\hline Widowed/Divorced/Separated & $\begin{array}{l}0.107 \\
(0.309)\end{array}$ & $\begin{array}{c}0.159 \\
(0.366)\end{array}$ & $\begin{array}{c}0.113 \\
(0.316)\end{array}$ & $\begin{array}{c}0.165 \\
(0.372)\end{array}$ \\
\hline Single/Never Married & $\begin{array}{l}0.179 \\
(0.383)\end{array}$ & $\begin{array}{c}0.201 \\
(0.401)\end{array}$ & $\begin{array}{c}0.225 \\
(0.418)\end{array}$ & $\begin{array}{l}0.225 \\
(0.418)\end{array}$ \\
\hline Licensure & $\begin{array}{l}1.000 \\
(0.000)\end{array}$ & $\begin{array}{l}1.000 \\
(0.000)\end{array}$ & $\begin{array}{c}0.000 \\
(0.000)\end{array}$ & $\begin{array}{l}0.000 \\
(0.000)\end{array}$ \\
\hline Duration & $\begin{array}{l}111.389 \\
(26.823)\end{array}$ & $\begin{array}{c}51.992 \\
(29.138)\end{array}$ & $\begin{array}{c}0.000 \\
(0.000)\end{array}$ & $\begin{array}{c}0.000 \\
(0.000)\end{array}$ \\
\hline $\begin{array}{l}\text { Hourly Wage } \\
\text { (2014 CPI) }\end{array}$ & $\begin{array}{l}62.538 \\
(52.216)\end{array}$ & $\begin{array}{c}28.928 \\
(17.738)\end{array}$ & $\begin{array}{c}22.356 \\
(11.157)\end{array}$ & $\begin{array}{c}25.792 \\
(22.683)\end{array}$ \\
\hline Weeks per Year & $\begin{array}{l}51.220 \\
(0.873)\end{array}$ & $\begin{array}{l}51.256 \\
(0.815)\end{array}$ & $\begin{array}{l}51.231 \\
(1.135)\end{array}$ & $\begin{array}{l}51.325 \\
(0.814)\end{array}$ \\
\hline Hours per Week & $\begin{array}{l}48.498 \\
(12.273)\end{array}$ & $\begin{array}{l}42.375 \\
(7.342)\end{array}$ & $\begin{array}{l}42.538 \\
(7.169)\end{array}$ & $\begin{array}{l}42.977 \\
(7.681)\end{array}$ \\
\hline Hours per Year & $\begin{array}{l}2484.383 \\
(631.288) \\
\end{array}$ & $\begin{array}{r}2172.065 \\
(378.260) \\
\end{array}$ & $\begin{array}{l}2179.171 \\
(369.992) \\
\end{array}$ & $\begin{array}{r}2206.053 \\
(397.182) \\
\end{array}$ \\
\hline Observations & 411,897 & $1,523,655$ & 61,490 & $9,243,914$ \\
\hline Weighted Observations & $31,477,479$ & $118,617,772$ & $2,429,584$ & $687,525,536$ \\
\hline
\end{tabular}

Note: Occupations that did not change their regulations status include cosmetologists, dentists, physicians, pharmacists, and lawyers. Occupations that changed their regulation status include architects, accountants, barbers, occupational therapists, physical therapists, practical nurses, registered nurses, and teachers. We manually determine whether each occupation was ever licensed by verifying licensing status through the variable occ1990. For the 1940 census data which lacks the occ1990 variable, we made a crosswalk between occ1990 and occ1950. Data are weighted using population weights. 
Table 4. Effects of Licensing Duration on Log Hourly Earnings Panel A. 13 Universally Licensed Occupations

\begin{tabular}{|c|c|c|c|c|c|c|c|c|c|}
\hline & (1) & $(2)$ & (3) & (4) & (5) & (6) & (7) & (8) & (9) \\
\hline Control Group: & \multicolumn{6}{|c|}{$\begin{array}{l}\text { Relative to Individuals in Never Licensed Occupations Throughout Our Period of } \\
\text { Analysis }\end{array}$} & \multicolumn{3}{|c|}{$\begin{array}{l}\text { Relative to Unlicensed Workers in } \\
\text { Universally Licensed Occupations Prior } \\
\text { to States Passing Licensing Statutes }\end{array}$} \\
\hline Licensure & $\begin{array}{l}0.082^{* * *} \\
(0.019)\end{array}$ & $\begin{array}{l}0.075^{* * *} \\
(0.020)\end{array}$ & & & & & $\begin{array}{c}0.205^{* * *} \\
(0.015)\end{array}$ & & \\
\hline Duration & & & $\begin{array}{l}0.002 * * * \\
(0.000)\end{array}$ & $\begin{array}{l}0.002^{* * *} \\
(0.000)\end{array}$ & & & & $\begin{array}{l}0.005^{* * *} \\
(0.000)\end{array}$ & \\
\hline Duration Dummies: & & & & & & & & & \\
\hline Duration $\in[0.3]$ & & & & & $\begin{array}{c}0.035^{* * *} \\
(0.012)\end{array}$ & $\begin{array}{c}0.031 * * \\
(0.012)\end{array}$ & & & $\begin{array}{c}0.000 \\
(0.013)\end{array}$ \\
\hline Duration $\in[4.10]$ & & & & & $\begin{array}{l}0.055^{* * *} \\
(0.014)\end{array}$ & $\begin{array}{l}0.049 * * * \\
(0.014)\end{array}$ & & & $\begin{array}{l}-0.012 \\
(0.015)\end{array}$ \\
\hline Duration $\in[11.20]$ & & & & & $\begin{array}{l}0.036^{*} \\
(0.021)\end{array}$ & $\begin{array}{c}0.027 \\
(0.022)\end{array}$ & & & $\begin{array}{c}-0.009 \\
(0.020)\end{array}$ \\
\hline Duration $\in[21.30]$ & & & & & $\begin{array}{c}0.070 * * * \\
(0.023)\end{array}$ & $\begin{array}{c}0.062^{* * *} \\
(0.024)\end{array}$ & & & $\begin{array}{c}0.114^{* * *} \\
(0.031)\end{array}$ \\
\hline Duration $\in[31.40]$ & & & & & $\begin{array}{c}0.093 * * * \\
(0.023)\end{array}$ & $\begin{array}{c}0.086 * * * \\
(0.024)\end{array}$ & & & $\begin{array}{c}0.252^{* * *} \\
(0.035)\end{array}$ \\
\hline Duration $\in[41.50]$ & & & & & $\begin{array}{c}0.094 * * * \\
(0.023)\end{array}$ & $\begin{array}{c}0.087 * * * \\
(0.023)\end{array}$ & & & $\begin{array}{c}0.306^{* * *} \\
(0.032)\end{array}$ \\
\hline Duration $\in[51.100]$ & & & & & $\begin{array}{c}0.150 * * * \\
(0.025)\end{array}$ & $\begin{array}{c}0.143^{* * *} \\
(0.026)\end{array}$ & & & $\begin{array}{c}0.362 * * * \\
(0.031)\end{array}$ \\
\hline Duration $>100$ & & & & & $\begin{array}{c}0.209 * * * \\
(0.028)\end{array}$ & $\begin{array}{c}0.201^{* * *} \\
(0.029)\end{array}$ & & & $\begin{array}{c}0.647 * * * \\
(0.038)\end{array}$ \\
\hline Individual Covariates & YES & YES & YES & YES & YES & YES & YES & YES & YES \\
\hline OCC FE & YES & YES & YES & YES & YES & YES & NO & NO & $\mathrm{NO}$ \\
\hline Year FE & YES & YES & YES & YES & YES & YES & YES & YES & YES \\
\hline State FE & YES & YES & YES & YES & YES & YES & YES & YES & YES \\
\hline 1-digit SOC 2000 & $\mathrm{NO}$ & NO & NO & $\mathrm{NO}$ & $\mathrm{NO}$ & $\mathrm{NO}$ & NO & NO & NO \\
\hline 2-digit SOC 2000 & YES & NO & YES & NO & YES & NO & NO & NO & NO \\
\hline 3-digit SOC 2000 & NO & YES & NO & YES & NO & YES & NO & NO & NO \\
\hline $\mathrm{H}_{0}$ : All Duration Dummies $=0$ & & & & & 0.000 & 0.000 & & & 0.000 \\
\hline R-squared & 0.423 & 0.449 & 0.424 & 0.449 & 0.424 & 0.449 & 0.304 & 0.376 & 0.381 \\
\hline Observations & $11,240,956$ & $11,240,956$ & $11,240,956$ & $11,240,956$ & $11,240,956$ & $11,240,956$ & $1,997,042$ & $1,997,042$ & $1,997,042$ \\
\hline
\end{tabular}


B. Occupations that Changed Their Regulation Status over the Period of Our Analysis

\begin{tabular}{|c|c|c|c|c|c|c|c|c|c|}
\hline & (1) & (2) & (3) & (4) & (5) & (6) & (7) & (8) & (9) \\
\hline Control Group: & \multicolumn{6}{|c|}{$\begin{array}{c}\text { Relative to Individuals in Never Licensed Occupations Throughout Our Period of } \\
\text { Analysis }\end{array}$} & \multicolumn{3}{|c|}{$\begin{array}{l}\text { Relative to Unlicensed Workers in } \\
\text { Universally Licensed Occupations Priol } \\
\text { to States Passing Licensing Statutes }\end{array}$} \\
\hline Licensure & $\begin{array}{c}0.091^{* * *} \\
(0.019)\end{array}$ & $\begin{array}{c}0.084^{* * *} \\
(0.020)\end{array}$ & & & & & $\begin{array}{c}0.147 * * * \\
(0.020)\end{array}$ & & \\
\hline Duration & & & $\begin{array}{l}0.002^{* * *} \\
(0.000)\end{array}$ & $\begin{array}{l}0.002^{* * *} \\
(0.000)\end{array}$ & & & & $\begin{array}{l}0.004^{* * *} \\
(0.000)\end{array}$ & \\
\hline Duration Dummies: & & & & & & & & & \\
\hline Duration $\in[0.3]$ & & & & & $\begin{array}{c}0.039 * * * \\
(0.013)\end{array}$ & $\begin{array}{c}0.036 * * * \\
(0.012)\end{array}$ & & & $\begin{array}{c}0.008 \\
(0.012)\end{array}$ \\
\hline Duration $\in[4.10]$ & & & & & $\begin{array}{c}0.062 * * * \\
(0.014)\end{array}$ & $\begin{array}{c}0.056^{* * *} \\
(0.014)\end{array}$ & & & $\begin{array}{c}0.004 \\
(0.016)\end{array}$ \\
\hline Duration $\in[11.20]$ & & & & & $\begin{array}{l}0.045^{* *} \\
(0.021)\end{array}$ & $\begin{array}{c}0.035 \\
(0.022)\end{array}$ & & & $\begin{array}{c}0.016 \\
(0.019)\end{array}$ \\
\hline Duration $\in[21.30]$ & & & & & $\begin{array}{c}0.077 * * * \\
(0.023)\end{array}$ & $\begin{array}{c}0.069 * * * \\
(0.024)\end{array}$ & & & $\begin{array}{c}0.123^{* * *} \\
(0.030)\end{array}$ \\
\hline Duration $\in[31.40]$ & & & & & $\begin{array}{c}0.101^{* * *} \\
(0.023)\end{array}$ & $\begin{array}{c}0.094 * * * \\
(0.024)\end{array}$ & & & $\begin{array}{c}0.257 * * * \\
(0.034)\end{array}$ \\
\hline Duration $\in[41.50]$ & & & & & $\begin{array}{c}0.104^{* * * *} \\
(0.023)\end{array}$ & $\begin{array}{c}0.096 * * * \\
(0.023)\end{array}$ & & & $\begin{array}{c}0.321^{* * *} \\
(0.030)\end{array}$ \\
\hline Duration $\in[51.100]$ & & & & & $\begin{array}{c}0.159 * * * \\
(0.025)\end{array}$ & $\begin{array}{c}0.152 * * * \\
(0.026)\end{array}$ & & & $\begin{array}{c}0.378^{* * *} \\
(0.030)\end{array}$ \\
\hline Duration $>100$ & & & & & $\begin{array}{l}0.203^{* * *} \\
(0.028)\end{array}$ & $\begin{array}{l}0.195 * * * \\
(0.028)\end{array}$ & & & $\begin{array}{l}0.415^{* * *} \\
(0.042)\end{array}$ \\
\hline Individual Covariates & YES & YES & YES & YES & YES & YES & YES & YES & YES \\
\hline OCC FE & YES & YES & YES & YES & YES & YES & NO & NO & NO \\
\hline Year FE & YES & YES & YES & YES & YES & YES & YES & YES & YES \\
\hline State FE & YES & YES & YES & YES & YES & YES & YES & YES & YES \\
\hline 1-digit SOC 2000 & NO & NO & NO & NO & NO & NO & NO & NO & NO \\
\hline 2-digit SOC 2000 & YES & NO & YES & NO & YES & $\mathrm{NO}$ & NO & NO & NO \\
\hline 3-digit SOC 2000 & $\mathrm{NO}$ & YES & NO & YES & $\mathrm{NO}$ & YES & NO & NO & NO \\
\hline $\mathrm{H}_{0}$ : All Duration Dummies $=0$ & & & & & 0.000 & 0.000 & & & 0.000 \\
\hline R-squared & 0.392 & 0.421 & 0.392 & 0.421 & 0.392 & 0.421 & 0.218 & 0.254 & 0.272 \\
\hline Observations & $10,829,059$ & $10,829,059$ & $10,829,059$ & $10,829,059$ & $10,829,059$ & $10,829,059$ & $1,585,145$ & $1,585,145$ & $1,585,145$ \\
\hline
\end{tabular}


Table 5. Effects of Licensing Duration on Total Worked Hours per Year

Panel A. 13 Universally Licensed Occupations

\begin{tabular}{|c|c|c|c|c|c|c|c|c|c|}
\hline & (1) & $(2)$ & (3) & (4) & (5) & $(6)$ & (7) & $(8)$ & (9) \\
\hline Control Group: & \multicolumn{6}{|c|}{$\begin{array}{c}\text { Relative to Individuals in Never Licensed Occupations Throughout Our Period of } \\
\text { Analysis }\end{array}$} & \multicolumn{3}{|c|}{$\begin{array}{l}\text { Relative to Unlicensed Workers in } \\
\text { Universally Licensed Occupations Prior } \\
\text { to States Passing Licensing Statutes }\end{array}$} \\
\hline Licensure & $\begin{array}{c}31.225^{* *} \\
(15.066)\end{array}$ & $\begin{array}{c}36.389 * * \\
(14.369)\end{array}$ & & & & & $\begin{array}{c}73.040^{* * *} \\
(16.359)\end{array}$ & & \\
\hline Duration & & & $\begin{array}{l}-0.247 \\
(0.198)\end{array}$ & $\begin{array}{l}-0.214 \\
(0.201)\end{array}$ & & & & $\begin{array}{c}1.880 * * * \\
(0.233)\end{array}$ & \\
\hline Duration $\in[0.3]$ & & & & & $\begin{array}{c}8.108 \\
(8.859)\end{array}$ & $\begin{array}{l}12.633 \\
(8.797)\end{array}$ & & & $\begin{array}{l}30.027 * * * \\
(9.476)\end{array}$ \\
\hline Duration $\in[4.10]$ & & & & & $\begin{array}{c}39.051 * * * \\
(11.842)\end{array}$ & $\begin{array}{c}44.124^{* * *} \\
(11.562)\end{array}$ & & & $\begin{array}{l}58.978 * * * \\
(10.511)\end{array}$ \\
\hline Duration $\in[11.20]$ & & & & & $\begin{array}{c}72.913 * * * \\
(19.383)\end{array}$ & $\begin{array}{c}\text { 77.685*** } \\
(18.848)\end{array}$ & & & $\begin{array}{c}89.840 * * * \\
(16.825)\end{array}$ \\
\hline Duration $\in[21.30]$ & & & & & $\begin{array}{l}28.455^{*} \\
(16.504)\end{array}$ & $\begin{array}{c}32.874 * * \\
(15.833)\end{array}$ & & & $\begin{array}{c}53.395^{* * *} \\
(17.299)\end{array}$ \\
\hline Duration $\in[31.40]$ & & & & & $\begin{array}{c}23.356 \\
(16.427)\end{array}$ & $\begin{array}{l}29.059 * \\
(15.748)\end{array}$ & & & $\begin{array}{l}40.984 * * \\
(17.586)\end{array}$ \\
\hline Duration $\in[41.50]$ & & & & & $\begin{array}{c}20.871 \\
(16.989)\end{array}$ & $\begin{array}{c}26.411 \\
(16.238)\end{array}$ & & & $\begin{array}{l}33.789 * * \\
(17.093)\end{array}$ \\
\hline Duration $\in[51.100]$ & & & & & $\begin{array}{c}9.768 \\
(18.841)\end{array}$ & $\begin{array}{c}15.631 \\
(18.161)\end{array}$ & & & $\begin{array}{c}66.885^{* * *} \\
(17.080)\end{array}$ \\
\hline Duration $>100$ & & & & & $\begin{array}{c}20.635 \\
(20.769)\end{array}$ & $\begin{array}{c}26.742 \\
(19.969)\end{array}$ & & & $\begin{array}{c}259.353 * * * \\
(30.508)\end{array}$ \\
\hline Individual Covariates & YES & YES & YES & YES & YES & YES & YES & YES & YES \\
\hline OCC FE & YES & YES & YES & YES & YES & YES & NO & $\mathrm{NO}$ & NO \\
\hline Year FE & YES & YES & YES & YES & YES & YES & YES & YES & YES \\
\hline State FE & YES & YES & YES & YES & YES & YES & YES & YES & YES \\
\hline 1-digit SOC 2000 & $\mathrm{NO}$ & NO & NO & NO & NO & NO & NO & NO & NO \\
\hline 2-digit SOC 2000 & YES & NO & YES & NO & YES & NO & NO & NO & NO \\
\hline 3-digit SOC 2000 & $\mathrm{NO}$ & YES & NO & YES & $\mathrm{NO}$ & YES & NO & NO & NO \\
\hline $\mathrm{H}_{0}$ : All Duration Dummies $=0$ & & & & & 0.006 & 0.005 & & & 0.000 \\
\hline R-squared & 0.139 & 0.154 & 0.139 & 0.154 & 0.140 & 0.154 & 0.104 & 0.122 & 0.130 \\
\hline Observations & $11,240,956$ & $11,240,956$ & $11,240,956$ & $11,240,956$ & $11,240,956$ & $11,240,956$ & $1,997,042$ & $1,997,042$ & $1,997,042$ \\
\hline
\end{tabular}

Note: All models include indicators for gender, race (white vs. others), dummies for marital status (married, married but absent, separated/divorced/widowed vs. unmarried), years of education, potential experience and a quadratic function in potential experience; *** significant at the 0.01 level; ** significant at the 0.05 level; * significant at the 0.1 level; standard errors are constructed using the heteroscedasticity robust covariance matrix that allows for clustering at the state-occupation level. 
Panel B. Occupations that Changed Regulation Status over the Period of Our Analysis

\begin{tabular}{|c|c|c|c|c|c|c|c|c|c|}
\hline & $(1)$ & $(2)$ & (3) & (4) & (5) & (6) & (7) & (8) & (9) \\
\hline Control Group: & \multicolumn{6}{|c|}{$\begin{array}{c}\text { Relative to Individuals in Never Licensed Occupations Throughout Our Period of } \\
\text { Analysis }\end{array}$} & \multicolumn{3}{|c|}{$\begin{array}{l}\text { Relative to Unlicensed Workers in } \\
\text { Universally Licensed Occupations Prior } \\
\text { to States Passing Licensing Statutes }\end{array}$} \\
\hline Licensure & $\begin{array}{l}31.218^{* *} \\
(14.915)\end{array}$ & $\begin{array}{l}36.494^{* *} \\
(14.198)\end{array}$ & & & & & $\begin{array}{c}13.870 \\
(11.653)\end{array}$ & & \\
\hline Duration & & & $\begin{array}{l}-0.189 \\
(0.250)\end{array}$ & $\begin{array}{l}-0.148 \\
(0.257)\end{array}$ & & & & $\begin{array}{c}0.379 * * \\
(0.147)\end{array}$ & \\
\hline Duration $\in[0.3]$ & & & & & $\begin{array}{c}8.464 \\
(8.839)\end{array}$ & $\begin{array}{l}13.072 \\
(8.780)\end{array}$ & & & $\begin{array}{l}13.471^{*} \\
(7.780)\end{array}$ \\
\hline Duration $\in[4.10]$ & & & & & $\begin{array}{c}39.316 * * * \\
(11.751)\end{array}$ & $\begin{array}{c}44.484 * * * \\
(11.464)\end{array}$ & & & $\begin{array}{c}33.383 * * * \\
(7.903)\end{array}$ \\
\hline Duration $\in[11.20]$ & & & & & $\begin{array}{c}72.445 * * * \\
(19.244)\end{array}$ & $\begin{array}{c}77.302 * * * \\
(18.693)\end{array}$ & & & $\begin{array}{c}52.087 * * * \\
(13.245)\end{array}$ \\
\hline Duration $\in[21.30]$ & & & & & $\begin{array}{l}28.330 * \\
(16.349)\end{array}$ & $\begin{array}{l}32.792 * * \\
(15.659)\end{array}$ & & & $\begin{array}{c}10.092 \\
(13.598)\end{array}$ \\
\hline Duration $\in[31.40]$ & & & & & $\begin{array}{c}23.062 \\
(16.278)\end{array}$ & $\begin{array}{l}28.880^{*} \\
(15.578)\end{array}$ & & & $\begin{array}{l}-12.515 \\
(14.682)\end{array}$ \\
\hline Duration $\in[41.50]$ & & & & & $\begin{array}{c}21.072 \\
(16.853)\end{array}$ & $\begin{array}{l}26.733^{*} \\
(16.073)\end{array}$ & & & -24.330 \\
\hline Duration $\in[51.100]$ & & & & & $\begin{array}{c}10.562 \\
(18.580)\end{array}$ & $\begin{array}{c}16.469 \\
(17.851)\end{array}$ & & & $\begin{array}{c}0.698 \\
(14.056)\end{array}$ \\
\hline Duration $>100$ & & & & & $\begin{array}{l}37.004 * \\
(19.477)\end{array}$ & $\begin{array}{l}42.909 * * \\
(18.417)\end{array}$ & & & $\begin{array}{c}64.980 * * * \\
(16.501)\end{array}$ \\
\hline Individual Covariates & YES & YES & YES & YES & YES & YES & YES & YES & YES \\
\hline OCC FE & YES & YES & YES & YES & YES & YES & NO & NO & NO \\
\hline Year FE & YES & YES & YES & YES & YES & YES & YES & YES & YES \\
\hline State FE & YES & YES & YES & YES & YES & YES & YES & YES & YES \\
\hline 1-digit SOC 2000 & NO & NO & NO & NO & NO & NO & NO & NO & NO \\
\hline 2-digit SOC 2000 & YES & NO & YES & NO & YES & NO & $\mathrm{NO}$ & NO & NO \\
\hline 3-digit SOC 2000 & NO & YES & NO & YES & NO & YES & NO & NO & NO \\
\hline $\mathrm{H}_{0}$ : All Duration Dummies $=0$ & & & & & 0.000 & 0.000 & & & 0.000 \\
\hline R-squared & 0.116 & 0.132 & 0.116 & 0.132 & 0.116 & 0.132 & 0.053 & 0.054 & 0.057 \\
\hline Observations & $10,829,059$ & $10,829,059$ & $10,829,059$ & $10,829,059$ & $10,829,059$ & $10,829,059$ & $1,585,145$ & $1,585,145$ & $1,585,145$ \\
\hline
\end{tabular}


Table 6. Descriptive Statistics for Grandfathered Workers

\begin{tabular}{|c|c|c|c|c|}
\hline \multirow[b]{2}{*}{ VARIABLES } & \multicolumn{3}{|c|}{13 Universally Licensed Occupations } & \multirow[b]{2}{*}{$\begin{array}{c}\text { Occupations } \\
\text { That Are } \\
\text { Unlicensed } \\
\text { Throughout Our } \\
\text { Period of } \\
\text { Analysis }\end{array}$} \\
\hline & $\begin{array}{l}\text { Grandfathered } \\
\text { Workers }\end{array}$ & New Entrants & $\begin{array}{c}\text { Unlicensed } \\
\text { Workers Prior to } \\
\text { States Passing } \\
\text { Licensing } \\
\text { Statutes }\end{array}$ & \\
\hline White & $\begin{array}{c}0.831 \\
(0.375)\end{array}$ & $\begin{array}{c}0.805 \\
(0.396)\end{array}$ & $\begin{array}{c}0.891 \\
(0.311)\end{array}$ & $\begin{array}{c}0.794 \\
(0.405)\end{array}$ \\
\hline Male & $\begin{array}{c}0.255 \\
(0.436)\end{array}$ & $\begin{array}{c}0.348 \\
(0.476)\end{array}$ & $\begin{array}{c}0.374 \\
(0.484)\end{array}$ & $\begin{array}{c}0.532 \\
(0.499)\end{array}$ \\
\hline Pot. Experience & $\begin{array}{l}27.424 \\
(9.467)\end{array}$ & $\begin{array}{c}19.350 \\
(10.943)\end{array}$ & $\begin{array}{c}17.266 \\
(10.961)\end{array}$ & $\begin{array}{c}22.327 \\
(11.458)\end{array}$ \\
\hline Education & $\begin{array}{l}15.920 \\
(2.049)\end{array}$ & $\begin{array}{l}16.034 \\
(1.970)\end{array}$ & $\begin{array}{l}15.896 \\
(2.127)\end{array}$ & $\begin{array}{l}13.450 \\
(2.359)\end{array}$ \\
\hline \multicolumn{5}{|l|}{ Marital Status: } \\
\hline Married & $\begin{array}{c}0.675 \\
(0.468)\end{array}$ & $\begin{array}{c}0.635 \\
(0.481)\end{array}$ & $\begin{array}{c}0.643 \\
(0.479)\end{array}$ & $\begin{array}{c}0.589 \\
(0.492)\end{array}$ \\
\hline Married Absent & $\begin{array}{c}0.015 \\
(0.120)\end{array}$ & $\begin{array}{c}0.016 \\
(0.127)\end{array}$ & $\begin{array}{c}0.019 \\
(0.137)\end{array}$ & $\begin{array}{c}0.020 \\
(0.142)\end{array}$ \\
\hline $\begin{array}{c}\text { Widowed/Divorced/Separat } \\
\text { ed }\end{array}$ & $\begin{array}{c}0.203 \\
(0.402)\end{array}$ & $\begin{array}{c}0.141 \\
(0.348)\end{array}$ & $\begin{array}{c}0.113 \\
(0.316)\end{array}$ & $\begin{array}{c}0.165 \\
(0.372)\end{array}$ \\
\hline Single/Never Married & $\begin{array}{c}0.107 \\
(0.309)\end{array}$ & $\begin{array}{c}0.208 \\
(0.406)\end{array}$ & $\begin{array}{c}0.225 \\
(0.418)\end{array}$ & $\begin{array}{c}0.225 \\
(0.418)\end{array}$ \\
\hline Licensure & $\begin{array}{c}1.000 \\
(0.000)\end{array}$ & $\begin{array}{l}1.000 \\
(0.000)\end{array}$ & $\begin{array}{c}0.000 \\
(0.000)\end{array}$ & $\begin{array}{c}0.000 \\
(0.000)\end{array}$ \\
\hline Duration & $\begin{array}{c}15.618 \\
(10.016)\end{array}$ & $\begin{array}{l}70.673 \\
(35.077)\end{array}$ & $\begin{array}{c}0.000 \\
(0.000)\end{array}$ & $\begin{array}{c}0.000 \\
(0.000)\end{array}$ \\
\hline $\begin{array}{c}\text { Hourly Wage } \\
\text { (2014 CPI) }\end{array}$ & $\begin{array}{c}25.257 \\
(12.011)\end{array}$ & $\begin{array}{c}37.343 \\
(33.184)\end{array}$ & $\begin{array}{c}22.356 \\
(11.157)\end{array}$ & $\begin{array}{c}25.792 \\
(22.683)\end{array}$ \\
\hline Weeks per Year & $\begin{array}{l}51.270 \\
(0.905)\end{array}$ & $\begin{array}{l}51.245 \\
(0.817)\end{array}$ & $\begin{array}{l}51.231 \\
(1.135)\end{array}$ & $\begin{array}{l}51.325 \\
(0.814)\end{array}$ \\
\hline Hours per Week & $\begin{array}{l}43.206 \\
(7.743)\end{array}$ & $\begin{array}{l}43.717 \\
(9.109)\end{array}$ & $\begin{array}{l}42.538 \\
(7.169)\end{array}$ & $\begin{array}{l}42.977 \\
(7.681)\end{array}$ \\
\hline Hours per Year & $\begin{array}{l}2215.182 \\
(398.917)\end{array}$ & $\begin{array}{l}2240.417 \\
(468.603)\end{array}$ & $\begin{array}{l}2179.171 \\
(369.992)\end{array}$ & $\begin{array}{l}2206.053 \\
(397.182)\end{array}$ \\
\hline Observations & 249,759 & $1,685,793$ & 61,490 & $9,243,914$ \\
\hline Weighted Observations & $16,970,178$ & $133,125,073$ & $2,429,584$ & $687,525,536$ \\
\hline
\end{tabular}

Note: The 13 universally licensed occupations include architects, accountants, barbers, cosmetologists, dentists, occupational therapists, physical therapists, practical nurses, physicians, pharmacists, registered nurses, lawyers, and teachers. We manually determine whether each occupation was ever licensed by verifying licensing status through the variable occ1990. For the 1940 census data which lacks the occ1990 variable, we made a crosswalk between occ1990 and occ1950. Data are weighted using population weights. 
Table 7. Estimates of the Influence of Grandfathering on Hourly Wage

\begin{tabular}{|c|c|c|c|c|c|c|c|c|c|}
\hline \multirow[b]{2}{*}{ VARIABLES } & (1) & $(2)$ & (3) & (4) & (5) & (6) & (7) & (8) & (9) \\
\hline & \multicolumn{6}{|c|}{$\begin{array}{l}\text { Relative to Individuals in Never Licensed Occupations Throughout Our Period of } \\
\text { Analysis }\end{array}$} & \multicolumn{3}{|c|}{$\begin{array}{l}\text { Relative to Unlicensed Workers in } \\
\text { Universally Licensed Occupations Prior } \\
\text { to States Passing Licensing Statutes }\end{array}$} \\
\hline Licensure & $\begin{array}{c}0.045^{* * *} \\
(0.016)\end{array}$ & $\begin{array}{l}0.040^{* *} \\
(0.016)\end{array}$ & & & & & $\begin{array}{l}0.035^{*} \\
(0.018)\end{array}$ & & \\
\hline Duration & & & $\begin{array}{c}0.003^{* * *} \\
(0.001)\end{array}$ & $\begin{array}{c}0.003^{* * *} \\
(0.001)\end{array}$ & & & & $\begin{array}{c}0.006^{* * *} \\
(0.002)\end{array}$ & \\
\hline Duration $\in[0.3]$ & & & & & $\begin{array}{c}0.028 * * * \\
(0.010)\end{array}$ & $\begin{array}{c}0.025 * * \\
(0.010)\end{array}$ & & & $\begin{array}{c}0.024 \\
(0.014)\end{array}$ \\
\hline Duration $\in[4.10]$ & & & & & $\begin{array}{c}0.038 * * * \\
(0.012)\end{array}$ & $\begin{array}{c}0.034^{* * *} \\
(0.012)\end{array}$ & & & $\begin{array}{c}0.052 * * \\
(0.021)\end{array}$ \\
\hline Duration $\in[11.20]$ & & & & & $\begin{array}{c}0.006 \\
(0.022)\end{array}$ & $\begin{array}{c}0.001 \\
(0.022)\end{array}$ & & & $\begin{array}{l}0.064 * * \\
(0.030)\end{array}$ \\
\hline Duration $\in[21.30]$ & & & & & $\begin{array}{l}0.057 * * \\
(0.022)\end{array}$ & $\begin{array}{c}0.053^{* *} \\
(0.022)\end{array}$ & & & $\begin{array}{c}0.117^{* *} \\
(0.050)\end{array}$ \\
\hline Duration $\in[31.40]$ & & & & & $\begin{array}{c}0.176^{* * *} \\
(0.028)\end{array}$ & $\begin{array}{c}0.169 * * * \\
(0.029)\end{array}$ & & & $\begin{array}{l}0.240^{* * *} \\
(0.074)\end{array}$ \\
\hline Duration $\in[41.50]$ & & & & & $\begin{array}{c}0.333 * * * \\
(0.019)\end{array}$ & $\begin{array}{c}0.313^{* * *} \\
(0.019)\end{array}$ & & & $\begin{array}{c}0.382 * * * \\
(0.072)\end{array}$ \\
\hline Duration $\in[51.100]$ & & & & & $\begin{array}{c}0.207^{* * *} \\
(0.023)\end{array}$ & $\begin{array}{c}0.156^{* * *} \\
(0.022)\end{array}$ & & & $\begin{array}{c}0.085 \\
(0.055)\end{array}$ \\
\hline Individual Covariates & YES & YES & YES & YES & YES & YES & YES & YES & YES \\
\hline OCC FE & YES & YES & YES & YES & YES & YES & NO & NO & NO \\
\hline Year FE & YES & YES & YES & YES & YES & YES & YES & YES & YES \\
\hline State FE & YES & YES & YES & YES & YES & YES & YES & YES & YES \\
\hline 1-digit SOC 2000 & NO & NO & NO & NO & NO & NO & NO & NO & NO \\
\hline 2-digit SOC 2000 & YES & NO & YES & NO & YES & NO & NO & NO & NO \\
\hline 3-digit SOC 2000 & NO & YES & NO & YES & NO & YES & NO & NO & NO \\
\hline $\mathrm{H}_{0}$ : All Duration Dummies $=0$ & & & & & 0.000 & 0.000 & & & 0.000 \\
\hline R-squared & 0.388 & 0.420 & 0.388 & 0.420 & 0.388 & 0.420 & 0.290 & 0.297 & 0.298 \\
\hline Observations & $9,555,163$ & $9,555,163$ & $9,555,163$ & $9,555,163$ & $9,555,163$ & $9,555,163$ & 311,249 & 311,249 & 311,249 \\
\hline
\end{tabular}

Note: All models include indicators for gender, race (white vs. others), dummies for marital status (married, married but absent, separated/divorced/widowed vs. unmarried), years of education, potential experience and a quadratic function in potential experience; *** significant at the 0.01 level; ** significant at the 0.05 level; * significant at the 0.1 level; standard errors are constructed using the heteroscedasticity robust covariance matrix that allows for clustering at the stateoccupation level. 
B. Occupations that Changed Their Regulation Status over the Period of Our Analysis

\begin{tabular}{|c|c|c|c|c|c|c|c|c|c|}
\hline \multirow[b]{2}{*}{ Control Group: } & $(1)$ & $(2)$ & (3) & $(4)$ & $(5)$ & $(6)$ & $(7)$ & $(8)$ & $(9)$ \\
\hline & \multicolumn{6}{|c|}{$\begin{array}{c}\text { Relative to Individuals in Never Licensed Occupations Throughout Our Period of } \\
\text { Analysis }\end{array}$} & \multicolumn{3}{|c|}{$\begin{array}{l}\text { Relative to Unlicensed Workers in } \\
\text { Universally Licensed Occupations Prior } \\
\text { to States Passing Licensing Statutes }\end{array}$} \\
\hline Licensure & $\begin{array}{c}0.044 * * \\
(0.016)\end{array}$ & $\begin{array}{c}0.038 * * \\
(0.016)\end{array}$ & & & & & $\begin{array}{c}0.034^{*} \\
(0.018)\end{array}$ & & \\
\hline Duration & & & $\begin{array}{c}0.003^{* * *} \\
(0.001)\end{array}$ & $\begin{array}{c}0.003^{* * *} \\
(0.001)\end{array}$ & & & & $\begin{array}{c}0.007 * * * \\
(0.002)\end{array}$ & \\
\hline Categorical Dummies: & & & & & & & & & \\
\hline Duration $\in[0.3]$ & & & & & $\begin{array}{c}0.028 * * * \\
(0.010)\end{array}$ & $\begin{array}{c}0.024 * * \\
(0.010)\end{array}$ & & & $\begin{array}{c}0.025 \\
(0.015)\end{array}$ \\
\hline Duration $\in[4.10]$ & & & & & $\begin{array}{c}0.038 * * * \\
(0.012)\end{array}$ & $\begin{array}{c}0.033 * * \\
(0.013)\end{array}$ & & & $\begin{array}{c}0.054^{* *} \\
(0.021)\end{array}$ \\
\hline Duration $\in[11.20]$ & & & & & $\begin{array}{c}0.006 \\
(0.022)\end{array}$ & $\begin{array}{c}0.000 \\
(0.022)\end{array}$ & & & $\begin{array}{c}0.066^{* *} \\
(0.031)\end{array}$ \\
\hline Duration $\in[21.30]$ & & & & & $\begin{array}{c}0.057 * * \\
(0.022)\end{array}$ & $\begin{array}{c}0.052 * * \\
(0.023)\end{array}$ & & & $\begin{array}{c}0.120 * * \\
(0.051)\end{array}$ \\
\hline Duration $\in[31.40]$ & & & & & $\begin{array}{l}0.177^{* * *} \\
(0.029)\end{array}$ & $\begin{array}{l}0.168 * * * \\
(0.030)\end{array}$ & & & $\begin{array}{l}0.243^{* * * *} \\
(0.075)\end{array}$ \\
\hline Duration $\in[41.50]$ & & & & & $\begin{array}{c}0.341^{* * *} \\
(0.019)\end{array}$ & $\begin{array}{l}0.318 * * * \\
(0.020)\end{array}$ & & & $\begin{array}{l}0.396 * * * \\
(0.074)\end{array}$ \\
\hline Duration $\in[51.100]$ & & & & & $\begin{array}{c}0.207 * * * \\
(0.023)\end{array}$ & $\begin{array}{c}0.155^{* * * *} \\
(0.022)\end{array}$ & & & $\begin{array}{c}0.085 \\
(0.056)\end{array}$ \\
\hline Individual Covariates & YES & YES & YES & YES & YES & YES & YES & YES & YES \\
\hline OCC FE & YES & YES & YES & YES & YES & YES & NO & NO & NO \\
\hline Year FE & YES & YES & YES & YES & YES & YES & YES & YES & YES \\
\hline State FE & YES & YES & YES & YES & YES & YES & YES & YES & YES \\
\hline 1-digit SOC 2000 & $\mathrm{NO}$ & $\mathrm{NO}$ & $\mathrm{NO}$ & $\mathrm{NO}$ & NO & NO & $\mathrm{NO}$ & NO & $\mathrm{NO}$ \\
\hline 2-digit SOC 2000 & YES & $\mathrm{NO}$ & YES & NO & YES & NO & NO & NO & NO \\
\hline 3-digit SOC 2000 & NO & YES & NO & YES & $\mathrm{NO}$ & YES & NO & NO & $\mathrm{NO}$ \\
\hline $\mathrm{H}_{0}$ : All Duration Dummies $=0$ & & & & & 0.000 & 0.000 & & & 0.000 \\
\hline R-squared & 0.388 & 0.420 & 0.388 & 0.420 & 0.388 & 0.420 & 0.289 & 0.297 & 0.298 \\
\hline Observations & $9,554,427$ & $9,554,427$ & $9,554,427$ & $9,554,427$ & $9,554,427$ & $9,554,427$ & 310,513 & 310,513 & 310,513 \\
\hline
\end{tabular}

Note: All models include indicators for gender, race (white vs. others), dummies for marital status (married, married but absent, separated/divorced/widowed vs. unmarried), years of education, potential experience and a quadratic function in potential experience; *** significant at the 0.01 level; ** significant at the 0.05 level; * significant at the 0.1 level; standard errors are constructed using the heteroscedasticity robust covariance matrix that allows for clustering at the state-occupation level. 
Table 8. Estimates of the Influence of Grandfathering on Hours Worked per Year

Panel A. 13 Universally Licensed Occupations

\begin{tabular}{|c|c|c|c|c|c|c|c|c|c|}
\hline & $(1)$ & $(2)$ & (3) & (4) & $(5)$ & (6) & (7) & (8) & (9) \\
\hline Control Group: & \multicolumn{6}{|c|}{$\begin{array}{c}\text { Relative to Individuals in Never Licensed Occupations Throughout Our Period of } \\
\text { Analysis }\end{array}$} & \multicolumn{3}{|c|}{$\begin{array}{l}\text { Relative to Unlicensed Workers in } \\
\text { Universally Licensed Occupations Prior } \\
\text { to States Passing Licensing Statutes }\end{array}$} \\
\hline Licensure & $\begin{array}{c}\text { 39.569*** } \\
(13.595)\end{array}$ & $\begin{array}{c}45.494 * * * \\
(13.281)\end{array}$ & & & & & $\begin{array}{c}15.012^{* *} \\
(6.945)\end{array}$ & & \\
\hline Duration & & & $\begin{array}{c}0.769 \\
(0.729)\end{array}$ & $\begin{array}{c}0.922 \\
(0.737)\end{array}$ & & & & $\begin{array}{l}-0.520 \\
(0.547)\end{array}$ & \\
\hline Duration $\in[0.3]$ & & & & & $\begin{array}{c}7.899 \\
(6.375)\end{array}$ & $\begin{array}{l}11.596 * \\
(6.687)\end{array}$ & & & $\begin{array}{l}12.127^{*} \\
(6.525)\end{array}$ \\
\hline Duration $\in[4.10]$ & & & & & $\begin{array}{c}32.591 * * * \\
(10.255)\end{array}$ & $\begin{array}{c}38.185^{* * * *} \\
(10.258)\end{array}$ & & & $\begin{array}{l}12.941 * \\
(7.633)\end{array}$ \\
\hline Duration $\in[11.20]$ & & & & & $\begin{array}{l}65.997 * * * \\
(20.703)\end{array}$ & $\begin{array}{l}72.299 * * * \\
(20.451)\end{array}$ & & & $\begin{array}{l}16.012^{*} \\
(9.471)\end{array}$ \\
\hline Duration $\in[21.30]$ & & & & & $\begin{array}{l}28.888 \\
(20.403)\end{array}$ & $\begin{array}{l}35.218^{*} \\
(19.980)\end{array}$ & & & $\begin{array}{c}16.098 \\
(13.682)\end{array}$ \\
\hline Duration $\in[31.40]$ & & & & & $\begin{array}{c}20.316 \\
(16.190)\end{array}$ & $\begin{array}{l}27.403^{*} \\
(15.738)\end{array}$ & & & $\begin{array}{l}-12.015 \\
(16.765)\end{array}$ \\
\hline Duration $\in[41.50]$ & & & & & $\begin{array}{l}20.039 \\
(17.504)\end{array}$ & $\begin{array}{c}24.479 \\
(17.266)\end{array}$ & & & $\begin{array}{l}-37.597 \\
(22.425)\end{array}$ \\
\hline Duration $\in[51.100]$ & & & & & $\begin{array}{c}-659.056 * * * \\
(26.953)\end{array}$ & $\begin{array}{c}-660.297 * * * \\
(28.005)\end{array}$ & & & $\begin{array}{c}-393.168 * * * \\
(33.549)\end{array}$ \\
\hline Individual Covariates & YES & YES & YES & YES & YES & YES & YES & YES & YES \\
\hline OCC FE & YES & YES & YES & YES & YES & YES & NO & NO & NO \\
\hline Year FE & YES & YES & YES & YES & YES & YES & YES & YES & YES \\
\hline State FE & YES & YES & YES & YES & YES & YES & YES & YES & YES \\
\hline 1-digit SOC 2000 & NO & NO & NO & NO & NO & NO & NO & NO & NO \\
\hline 2-digit SOC 2000 & YES & NO & YES & NO & YES & NO & NO & NO & NO \\
\hline 3-digit SOC 2000 & NO & YES & NO & YES & NO & YES & NO & NO & NO \\
\hline $\mathrm{H}_{0}$ : All Duration Dummies $=0$ & & & & & 0.000 & 0.000 & & & 0.000 \\
\hline R-squared & 0.123 & 0.141 & 0.123 & 0.141 & 0.123 & 0.141 & 0.060 & 0.060 & 0.060 \\
\hline Observations & $9,555,163$ & $9,555,163$ & $9,555,163$ & $9,555,163$ & $9,555,163$ & $9,555,163$ & 311,249 & 311,249 & 311,249 \\
\hline
\end{tabular}


Panel B. Occupations that Changed Regulation Status over the Period of Our Analysis

\begin{tabular}{|c|c|c|c|c|c|c|c|c|c|}
\hline & $(1)$ & $(2)$ & (3) & $(4)$ & (5) & $(6)$ & (7) & $(8)$ & (9) \\
\hline Control Group: & \multicolumn{6}{|c|}{$\begin{array}{c}\text { Relative to Individuals in Never Licensed Occupations Throughout Our Period of } \\
\text { Analysis }\end{array}$} & \multicolumn{3}{|c|}{$\begin{array}{l}\text { Relative to Unlicensed Workers in } \\
\text { Universally Licensed Occupations Prior } \\
\text { to States Passing Licensing Statutes }\end{array}$} \\
\hline$\overline{\text { Licensure }}$ & $\begin{array}{c}\text { 39.192*** } \\
(13.819)\end{array}$ & $\begin{array}{c}46.499 * * * \\
(13.299)\end{array}$ & & & & & $\begin{array}{l}13.057^{*} \\
(6.942)\end{array}$ & & \\
\hline Duration & & & $\begin{array}{c}0.748 \\
(0.739)\end{array}$ & $\begin{array}{c}0.939 \\
(0.749)\end{array}$ & & & & $\begin{array}{l}-0.614 \\
(0.550)\end{array}$ & \\
\hline Duration $\in[0.3]$ & & & & & $\begin{array}{c}7.471 \\
(6.366)\end{array}$ & $\begin{array}{l}12.364 * \\
(6.418)\end{array}$ & & & $\begin{array}{l}10.397 \\
(6.492)\end{array}$ \\
\hline Duration $\in[4.10]$ & & & & & $\begin{array}{l}32.192 * * * \\
(10.350)\end{array}$ & $\begin{array}{c}38.990 * * * \\
(10.194)\end{array}$ & & & $\begin{array}{l}10.838 \\
(7.619)\end{array}$ \\
\hline Duration $\in[11.20]$ & & & & & $\begin{array}{l}65.626 * * * \\
(20.898)\end{array}$ & $\begin{array}{l}73.239 * * * \\
(20.434)\end{array}$ & & & $\begin{array}{l}13.125 \\
(9.759)\end{array}$ \\
\hline Duration $\in[21.30]$ & & & & & $\begin{array}{l}28.073 \\
(20.769)\end{array}$ & $\begin{array}{l}36.034 * \\
(20.220)\end{array}$ & & & $\begin{array}{c}11.892 \\
(14.167)\end{array}$ \\
\hline Duration $\in[31.40]$ & & & & & $\begin{array}{l}19.729 \\
(16.502)\end{array}$ & $\begin{array}{l}28.722 * \\
(15.836)\end{array}$ & & & $\begin{array}{l}-15.985 \\
(17.123)\end{array}$ \\
\hline Duration $\in[41.50]$ & & & & & $\begin{array}{l}18.413 \\
(18.374)\end{array}$ & $\begin{array}{c}26.254 \\
(18.113)\end{array}$ & & & $\begin{array}{l}-43.612 * \\
(22.535)\end{array}$ \\
\hline Duration $\in[51.100]$ & & & & & $\begin{array}{c}-659.684 * * * \\
(27.116)\end{array}$ & $\begin{array}{c}-659.374 * * * \\
(28.442)\end{array}$ & & & $\begin{array}{c}-393.089 * * * \\
(32.945)\end{array}$ \\
\hline Individual Covariates & YES & YES & YES & YES & YES & YES & YES & YES & YES \\
\hline OCC FE & YES & YES & YES & YES & YES & YES & NO & NO & $\mathrm{NO}$ \\
\hline Year FE & YES & YES & YES & YES & YES & YES & YES & YES & YES \\
\hline State FE & YES & YES & YES & YES & YES & YES & YES & YES & YES \\
\hline 1-digit SOC 2000 & NO & NO & NO & NO & NO & NO & NO & NO & NO \\
\hline 2-digit SOC 2000 & YES & NO & YES & NO & YES & NO & NO & NO & NO \\
\hline 3-digit SOC 2000 & NO & YES & NO & YES & NO & YES & $\mathrm{NO}$ & $\mathrm{NO}$ & NO \\
\hline $\mathrm{H}_{0}:$ All Duration Dummies $=0$ & & & & & 0.000 & 0.000 & & & 0.000 \\
\hline R-squared & 0.123 & 0.141 & 0.123 & 0.141 & 0.123 & 0.141 & 0.060 & 0.060 & 0.060 \\
\hline Observations & $9,554,427$ & $9,554,427$ & $9,554,427$ & $9,554,427$ & $9,554,427$ & $9,554,427$ & 310,513 & 310,513 & 310,513 \\
\hline
\end{tabular}

Note: All models include indicators for gender, race (white vs. others), dummies for marital status (married, married but absent, separated/divorced/widowed vs. unmarried), years of education, potential experience and a quadratic function in potential experience; *** significant at the 0.01 level; ** significant at the 0.05 level; * significant at the 0.1 level; standard errors are constructed using the heteroscedasticity robust covariance matrix that allows for clustering at the state-occupation level. 
Table 9. Oaxaca Decomposition Analysis of New Entrants Relative to Grandfathered Workers

\begin{tabular}{|c|c|c|c|c|}
\hline & (1) & $(2)$ & (3) & (4) \\
\hline Sample: & \multicolumn{2}{|c|}{ The Census 1940-2000 and the ACS 2001-2015 } & \multicolumn{2}{|c|}{ The ACS 2001-2015 } \\
\hline Labor Market Outcome: & Hourly Wage & Hour Worked Per Year & Hourly Wage & Hour Worked Per Year \\
\hline New Entrants & $\begin{array}{c}3.3836 * * * \\
(0.000)\end{array}$ & $\begin{array}{c}2,243.3029 * * * \\
(0.141)\end{array}$ & $\begin{array}{c}3.4192 * * * \\
(0.001)\end{array}$ & $\begin{array}{c}2,232.2318 * * * \\
(0.452)\end{array}$ \\
\hline Grandfathered & $\begin{array}{c}3.1326 * * * \\
(0.000)\end{array}$ & $\begin{array}{c}2,201.1252^{* * *} \\
(0.205)\end{array}$ & $\begin{array}{c}3.1506 * * * \\
(0.001)\end{array}$ & $\begin{array}{c}2,223.9153^{* * *} \\
(1.118)\end{array}$ \\
\hline Difference & $\begin{array}{c}0.2509 * * * \\
(0.001)\end{array}$ & $\begin{array}{c}42.1777^{* * *} \\
(0.249)\end{array}$ & $\begin{array}{c}0.2685 * * * \\
(0.001)\end{array}$ & $\begin{array}{c}8.3165 * * * \\
(1.206)\end{array}$ \\
\hline Explained & $\begin{array}{c}0.2511 * * * \\
(0.001)\end{array}$ & $\begin{array}{c}137.4357 * * * \\
(0.262)\end{array}$ & $\begin{array}{c}0.2841 * * * \\
(0.001)\end{array}$ & $\begin{array}{c}105.2721 * * * \\
(1.196)\end{array}$ \\
\hline Unexplained & $\begin{array}{l}-0.0001 \\
(0.000)\end{array}$ & $\begin{array}{c}-95.2580^{* * *} \\
(0.122)\end{array}$ & $\begin{array}{c}-0.0156^{* * *} \\
(0.002)\end{array}$ & $\begin{array}{c}-96.9556 * * * \\
(1.568)\end{array}$ \\
\hline Observations & $1,935,610$ & $1,935,610$ & $1,175,854$ & $1,175,854$ \\
\hline
\end{tabular}

Note: Columns (1) and (2) use all sample from 1940-2015, and columns (3) and (4) use the ACS from 2001 to 2005 in order to provide analysis of individuals in occupations that states recently enacted licensing statutes. Differences between the wages/hours between grandfathered workers and new entrants can be explained by human capital characteristics and individual contributions such as gender, race (white vs. others), marital status (married, married but absent, separated/divorced/widowed vs. unmarried), years of education, potential experience, state, year, and three-digit SOC. 
Table 10. Effects of Licensing Duration on Labor Market Participation Panel A. 13 Universally Licensed Occupations

\begin{tabular}{|c|c|}
\hline & $(1)$ \\
\hline Duration $\in[1.4]$ & $\begin{array}{c}-0.013^{* * *} \\
(0.003)\end{array}$ \\
\hline Duration $\in[5.8]$ & $\begin{array}{c}-0.014 * * * \\
(0.003)\end{array}$ \\
\hline Duration $\in$ [9.12] & $\begin{array}{c}-0.011^{* * *} \\
(0.003)\end{array}$ \\
\hline Duration $\in$ [13.16] & $\begin{array}{c}-0.008^{* * *} \\
(0.002)\end{array}$ \\
\hline Duration $\in[17.20]$ & $\begin{array}{c}-0.010^{* * *} \\
(0.003)\end{array}$ \\
\hline Duration $\in[21.24]$ & $\begin{array}{c}-0.004 * * \\
(0.002)\end{array}$ \\
\hline Duration $\in$ [25.28] & $\begin{array}{c}-0.004^{* * *} \\
(0.001)\end{array}$ \\
\hline Duration $\in$ [29.32] & $\begin{array}{l}-0.002 \\
(0.002)\end{array}$ \\
\hline Duration $\in[33.36]$ & $\begin{array}{c}0.001 \\
(0.001)\end{array}$ \\
\hline Duration $\in[37.40]$ & $\begin{array}{l}-0.000 \\
(0.001)\end{array}$ \\
\hline Duration $\in[41.44]$ & $\begin{array}{c}0.001 \\
(0.001)\end{array}$ \\
\hline Duration $\in[45.48]$ & $\begin{array}{c}0.004^{* * *} \\
(0.001)\end{array}$ \\
\hline Duration $\in[49.52]$ & $\begin{array}{l}0.003^{*} \\
(0.002)\end{array}$ \\
\hline Duration $\in[53.56]$ & $\begin{array}{c}0.004^{* *} \\
(0.002)\end{array}$ \\
\hline Duration $\in[57.60]$ & $\begin{array}{c}0.006 * * * \\
(0.002)\end{array}$ \\
\hline Duration $\in[61.64]$ & $\begin{array}{c}0.004^{* * *} \\
(0.002)\end{array}$ \\
\hline Individual Covariates & YES \\
\hline Per Capita Income by State & YES \\
\hline State FE & YES \\
\hline Year FE & YES \\
\hline R-squared & 0.938 \\
\hline Observations & $32,961,456$ \\
\hline
\end{tabular}

Note: All models include indicators for gender, race (white vs. others), dummies for marital status (married, married but absent, separated/divorced/widowed vs. unmarried), years of education, potential experience and a quadratic function in potential experience; *** significant at the 0.01 level; ** significant at the 0.05 level; * significant at the 0.1 level; standard errors are constructed using the heteroscedasticity robust covariance matrix that allows for clustering at the state-occupation level. 
Panel B. Occupations that Changed Regulation Status over the Period of Our Analysis

\begin{tabular}{|c|c|}
\hline & $(1)$ \\
\hline Duration $\in[1.4]$ & $\begin{array}{c}-0.016^{* * *} \\
(0.004)\end{array}$ \\
\hline Duration $\in[5.8]$ & $\begin{array}{c}-0.016^{* * *} \\
(0.003)\end{array}$ \\
\hline Duration $\in$ [9.12] & $\begin{array}{c}-0.014 * * * \\
(0.003)\end{array}$ \\
\hline Duration $\in$ [13.16] & $\begin{array}{c}-0.010 * * * \\
(0.003)\end{array}$ \\
\hline Duration $\in[17.20]$ & $\begin{array}{c}-0.012^{* * *} \\
(0.003)\end{array}$ \\
\hline Duration $\in[21.24]$ & $\begin{array}{c}-0.006 * * * \\
(0.002)\end{array}$ \\
\hline Duration $\in$ [25.28] & $\begin{array}{c}-0.006 * * * \\
(0.002)\end{array}$ \\
\hline Duration $\in[29.32]$ & $\begin{array}{c}-0.004^{* *} \\
(0.002)\end{array}$ \\
\hline Duration $\in[33.36]$ & $\begin{array}{l}-0.001 \\
(0.002)\end{array}$ \\
\hline Duration $\in[37.40]$ & $\begin{array}{l}-0.002 \\
(0.002)\end{array}$ \\
\hline Duration $\in[41.44]$ & $\begin{array}{l}-0.001 \\
(0.002)\end{array}$ \\
\hline Duration $\in[45.48]$ & $\begin{array}{c}0.002 \\
(0.002)\end{array}$ \\
\hline Duration $\in$ [49.52] & $\begin{array}{c}0.001 \\
(0.002)\end{array}$ \\
\hline Duration $\in[53.56]$ & $\begin{array}{c}0.003 \\
(0.002)\end{array}$ \\
\hline Duration $\in[57.60]$ & $\begin{array}{c}0.004 * * \\
(0.002)\end{array}$ \\
\hline Duration $\in$ [61.64] & $\begin{array}{c}0.002 \\
(0.002)\end{array}$ \\
\hline Individual Covariates & YES \\
\hline Per Capita Income by State & YES \\
\hline State FE & YES \\
\hline Year FE & YES \\
\hline R-squared & 0.924 \\
\hline Observations & $32,961,456$ \\
\hline
\end{tabular}

Note: All models include indicators for gender, race (white vs. others), dummies for marital status (married, married but absent, separated/divorced/widowed vs. unmarried), years of education, potential experience and a quadratic function in potential experience; *** significant at the 0.01 level; ** significant at the 0.05 level; * significant at the 0.1 level; standard errors are constructed using the heteroscedasticity robust covariance matrix that allows for clustering at the state-occupation level. 
Appendix Figure 1. Potential Influence of the Grandfathering of New Regulations

\begin{tabular}{|l|l|l|}
\hline & New Entrants & \\
\hline $\begin{array}{l}\text { Pre-existing } \\
\text { Practitioners }\end{array}$ & $\begin{array}{l}\text { Pre-existing } \\
\text { Practitioners }\end{array}$ & New Entrants \\
& & \\
\hline Before Regulation & Duration= $\mathrm{t}_{1}$ & Duration= $\mathrm{t}_{2}$ \\
\hline
\end{tabular}


Appendix Figure 2. Estimated Licensing Effects on Log Hourly Wage before, during, and after Licensing Legislation: for Occupations that Changed Their Regulation Status

A. Relative to Individuals in Occupations That Are Unlicensed Throughout Our Period of Analysis

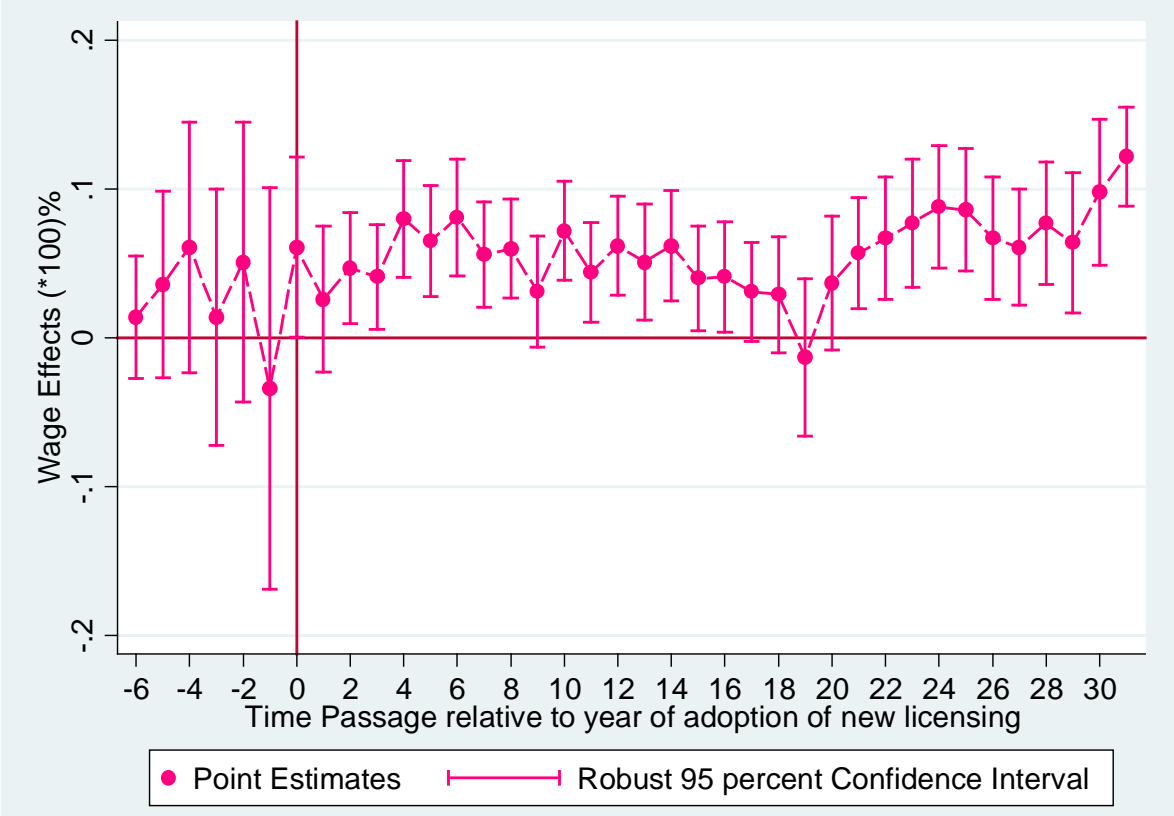

Note: Vertical bands represents \pm 1.96 times the standard error of each point estimate.

B. Relative to Individuals in Universally Licensed Occupations Prior to States Passing Licensing Statutes

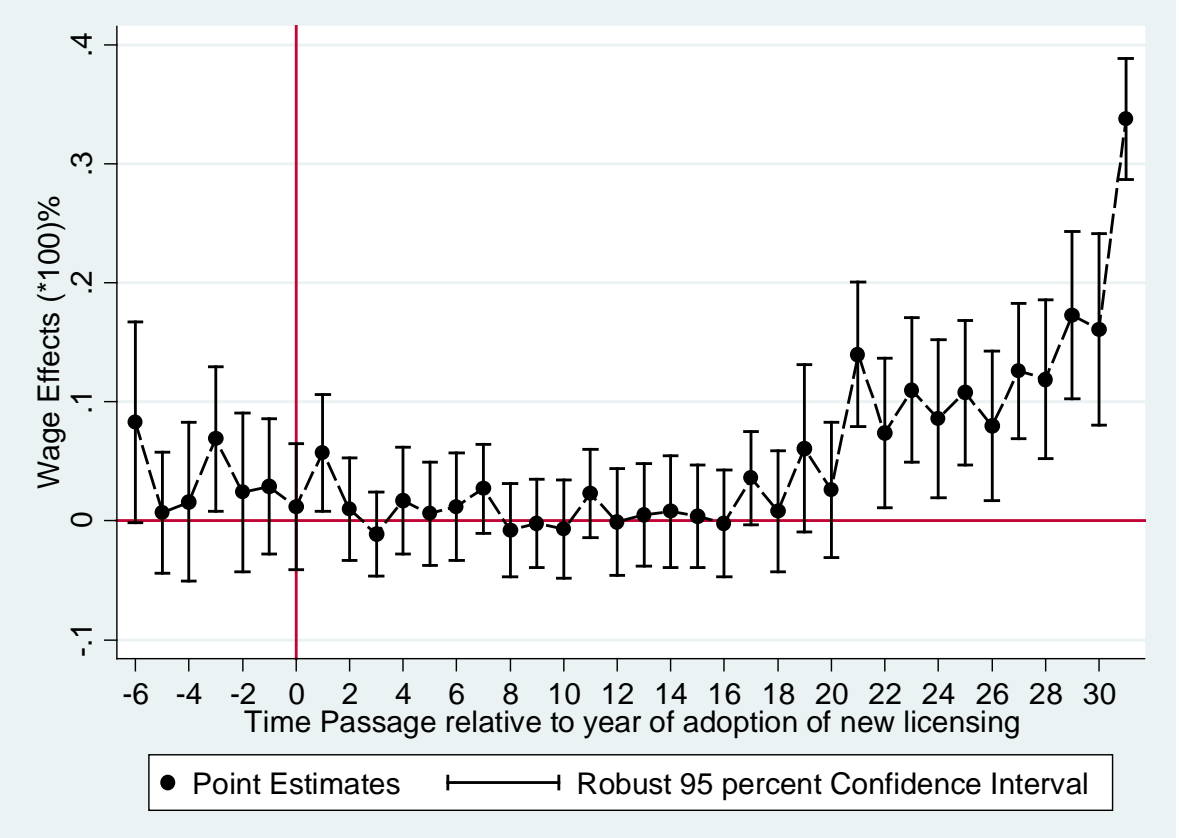

Note: Vertical bands represent \pm 1.96 times the standard error of each point estimate. 
Appendix Figure 3. Estimated Licensing Effects on Annual Hours Worked before, during, and after Licensing Legislation: for Occupations that Changed Their Regulation Status

A. Relative to Individuals in Occupations That Are Unlicensed Throughout Our Period of Analysis

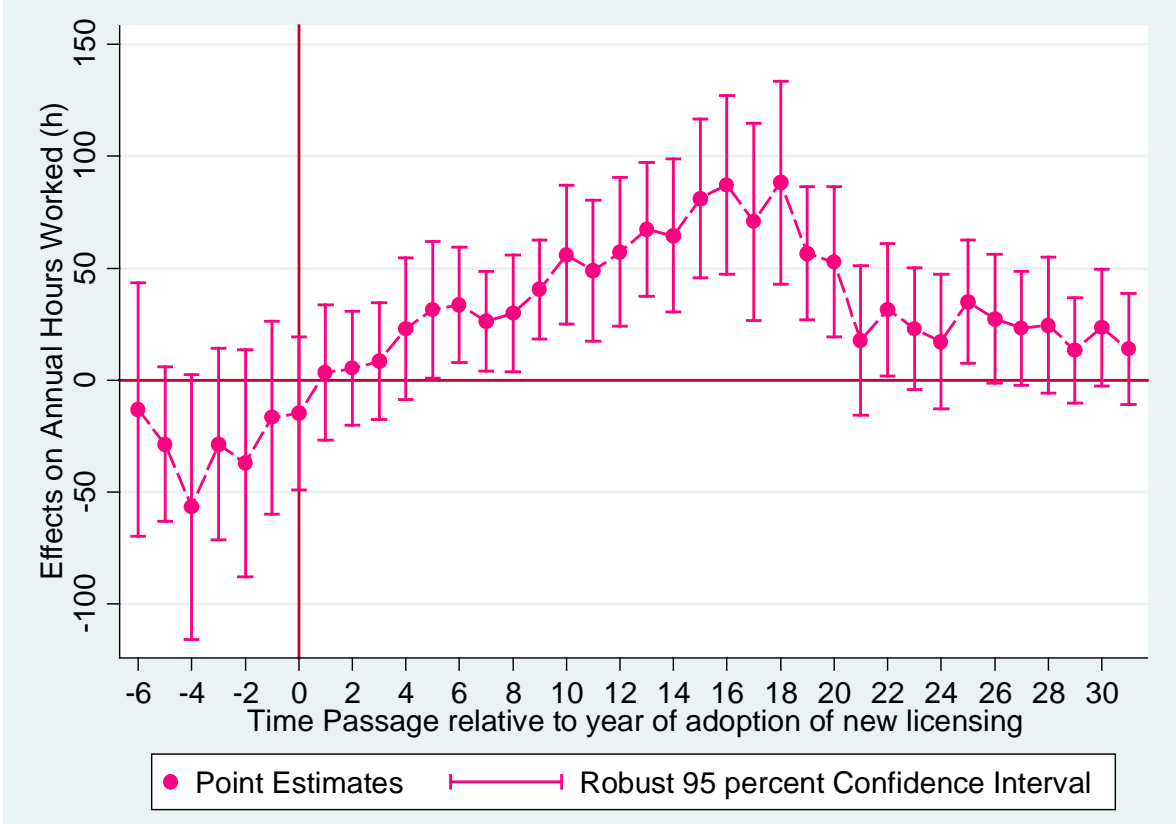

Note: Vertical bands represent \pm 1.96 times the standard error of each point estimate.

B. Relative to Individuals in Universally Licensed Occupations Prior to States Passing Licensing Statutes

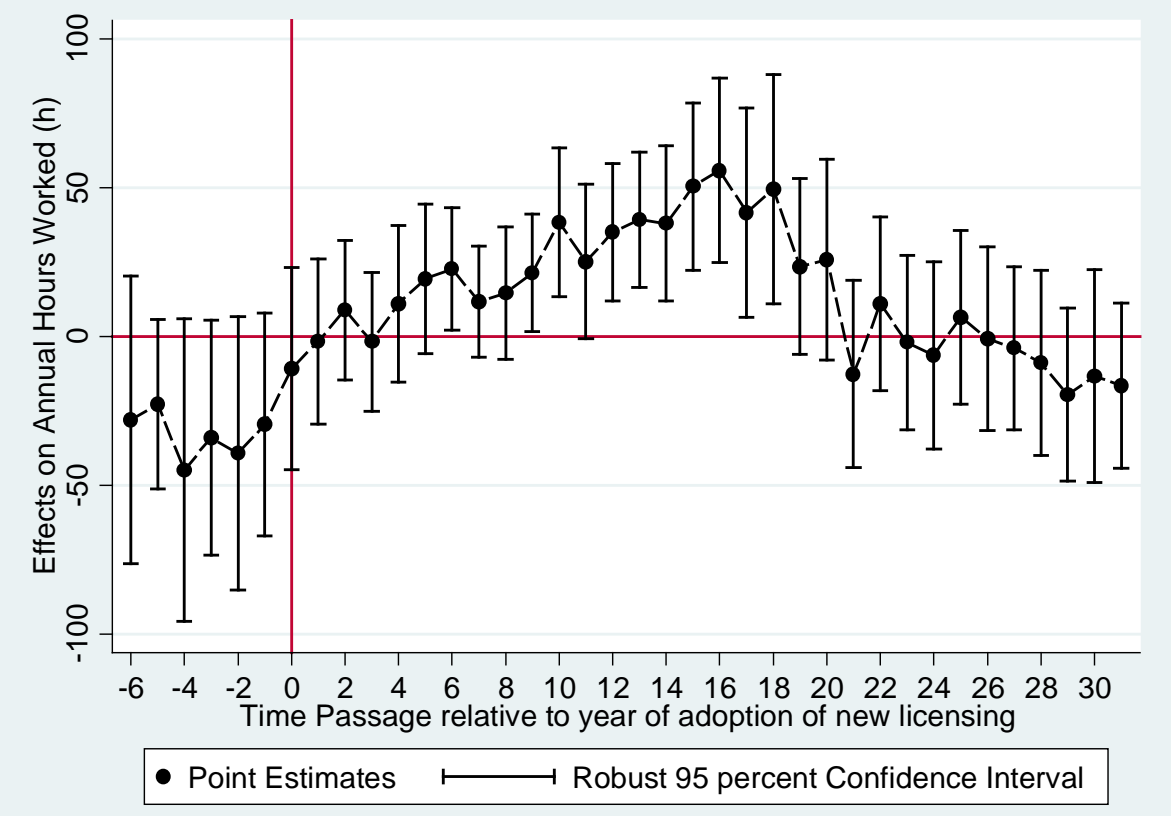

Note: Vertical bands represent \pm 1.96 times the standard error of each point estimate. 
Appendix Table 1: Number of Observations by year and Occupations with Regulation Status

\begin{tabular}{|c|c|c|c|c|c|c|}
\hline \multirow[b]{3}{*}{ Year } & \multicolumn{4}{|c|}{13 Universally Licensed Occupations } & \multirow{3}{*}{$\begin{array}{l}\text { Never Licensed } \\
\text { Occupations }\end{array}$} & \multirow{3}{*}{$\begin{array}{c}\text { Total } \\
\text { Observations }\end{array}$} \\
\hline & \multicolumn{2}{|c|}{$\begin{array}{l}\text { Occupations that changed } \\
\text { regulation status }\end{array}$} & \multicolumn{2}{|c|}{$\begin{array}{l}\text { Occupations that did not } \\
\text { change regulation status }\end{array}$} & & \\
\hline & Unlicensed & Licensed & Unlicensed & Licensed & & \\
\hline 1940 & 245,847 & 543,174 & 0 & 110,331 & $6,036,688$ & $6,936,040$ \\
\hline 1950 & 147,717 & 128,720 & 0 & 42,459 & $3,382,879$ & $3,701,775$ \\
\hline 1960 & 387,498 & 640,927 & 0 & 237,288 & $10,552,008$ & $11,817,721$ \\
\hline 1970 & 409,050 & $1,149,550$ & 0 & 362,150 & $14,281,550$ & $16,202,300$ \\
\hline 1980 & 389,000 & $2,246,660$ & 0 & 742,940 & $20,465,580$ & $23,844,180$ \\
\hline 1990 & 406,432 & $3,745,187$ & 0 & $1,229,389$ & $28,861,852$ & $34,242,860$ \\
\hline 2000 & 77,934 & $5,301,425$ & 0 & $1,483,711$ & $36,308,923$ & $43,171,993$ \\
\hline 2001 & 90,029 & $5,371,093$ & 0 & $1,508,659$ & $37,471,570$ & $44,441,351$ \\
\hline 2002 & 70,557 & $5,553,650$ & 0 & $1,523,655$ & $37,202,834$ & $44,350,696$ \\
\hline 2003 & 89,518 & $5,872,651$ & 0 & $1,602,930$ & $36,910,947$ & $44,476,046$ \\
\hline 2004 & 80,272 & $5,868,216$ & 0 & $1,662,698$ & $37,171,050$ & $44,782,236$ \\
\hline 2005 & 12,200 & $6,116,520$ & 0 & $1,742,930$ & $37,426,947$ & $45,298,597$ \\
\hline 2006 & 9,973 & $6,242,580$ & 0 & $1,746,885$ & $38,177,556$ & $46,176,994$ \\
\hline 2007 & 3,931 & $6,519,520$ & 0 & $1,805,055$ & $38,545,224$ & $46,873,730$ \\
\hline 2008 & 5,049 & $7,860,826$ & 0 & $1,910,641$ & $40,437,441$ & $50,213,957$ \\
\hline 2009 & 2,273 & $7,841,977$ & 0 & $1,927,770$ & $38,491,924$ & $48,263,944$ \\
\hline 2010 & 2,304 & $7,742,350$ & 0 & $1,881,423$ & $37,087,251$ & $46,713,328$ \\
\hline 2011 & 0 & $7,780,422$ & 0 & $1,927,001$ & $36,558,896$ & $46,266,319$ \\
\hline 2012 & 0 & $7,925,974$ & 0 & $1,969,993$ & $37,268,301$ & $47,164,268$ \\
\hline 2013 & 0 & $7,903,366$ & 0 & $2,008,417$ & $37,718,347$ & $47,630,130$ \\
\hline 2014 & 0 & $8,090,669$ & 0 & $1,987,798$ & $38,147,423$ & $48,225,890$ \\
\hline 2015 & 0 & $8,172,315$ & 0 & $2,063,356$ & $39,020,345$ & $49,256,016$ \\
\hline
\end{tabular}

Note: Occupations that changed their regulation status include architects, accountants, barbers, occupational therapists, physical therapists, practical nurses, registered nurses, and teachers. Occupations that did not change their regulations status include cosmetologists, dentists, physicians, pharmacists, and lawyers. We manually determine whether each occupation was ever licensed by verifying licensing status through the variable occ1990. For the 1940 census data which lacks the occ1990 variable, we made a crosswalk between occ1990 and occ1950. Data are weighted using population weights. 
Appendix Table 2: Mean of Hourly Wage and Duration by year and Regulation Status for Those Whose Licensing Status Changed

\begin{tabular}{|c|c|c|c|c|c|c|}
\hline \multirow[b]{4}{*}{ Year } & \multicolumn{5}{|c|}{13 Universally Licensed Occupations } & \multirow{4}{*}{$\begin{array}{c}\text { Never } \\
\begin{array}{c}\text { Licensed } \\
\text { Occupations }\end{array} \\
\text { Wage }\end{array}$} \\
\hline & \multirow{2}{*}{\multicolumn{2}{|c|}{$\begin{array}{c}\text { Occupations that did not change } \\
\text { regulation status } \\
\text { Licensed } \\
\end{array}$}} & \multicolumn{3}{|c|}{ Occupations that changed regulation status } & \\
\hline & & & \multicolumn{2}{|c|}{ Licensed } & \multirow{2}{*}{$\begin{array}{c}\text { Unlicensed } \\
\text { Wage }\end{array}$} & \\
\hline & Wage & Duration & Wage & Duration & & \\
\hline 1940 & $\begin{array}{c}20.427 \\
(11.182) \\
\end{array}$ & $\begin{array}{c}51.678 \\
(18.750) \\
\end{array}$ & $\begin{array}{l}12.411 \\
(6.831) \\
\end{array}$ & $\begin{array}{l}31.481 \\
(6.824) \\
\end{array}$ & $\begin{array}{l}13.597 \\
(8.020) \\
\end{array}$ & $\begin{array}{l}11.969 \\
(6.316) \\
\end{array}$ \\
\hline 1950 & $\begin{array}{c}20.621 \\
(11.622)\end{array}$ & $\begin{array}{c}60.566 \\
(18.637)\end{array}$ & $\begin{array}{l}18.396 \\
(7.741)\end{array}$ & $\begin{array}{c}33.848 \\
(16.447)\end{array}$ & $\begin{array}{l}14.150 \\
(5.644)\end{array}$ & $\begin{array}{l}13.781 \\
(6.489)\end{array}$ \\
\hline 1960 & $\begin{array}{c}30.573 \\
(20.859) \\
\end{array}$ & $\begin{array}{c}61.686 \\
(26.440) \\
\end{array}$ & $\begin{array}{c}23.242 \\
(10.629) \\
\end{array}$ & $\begin{array}{c}34.568 \\
(21.094) \\
\end{array}$ & $\begin{array}{l}19.886 \\
(7.612) \\
\end{array}$ & $\begin{array}{l}20.120 \\
(9.709) \\
\end{array}$ \\
\hline 1970 & $\begin{array}{c}40.838 \\
(29.280)\end{array}$ & $\begin{array}{c}71.606 \\
(26.015)\end{array}$ & $\begin{array}{l}28.621 \\
(13.087)\end{array}$ & $\begin{array}{c}35.604 \\
(24.406)\end{array}$ & $\begin{array}{c}25.550 \\
(10.029)\end{array}$ & $\begin{array}{c}25.496 \\
(14.325)\end{array}$ \\
\hline 1980 & $\begin{array}{c}42.468 \\
(28.282) \\
\end{array}$ & $\begin{array}{c}84.557 \\
(24.518) \\
\end{array}$ & $\begin{array}{c}25.594 \\
(11.432) \\
\end{array}$ & $\begin{array}{c}36.404 \\
(25.897) \\
\end{array}$ & $\begin{array}{l}22.237 \\
(8.785) \\
\end{array}$ & $\begin{array}{c}23.984 \\
(13.584) \\
\end{array}$ \\
\hline 1990 & $\begin{array}{c}51.218 \\
(42.007) \\
\end{array}$ & $\begin{array}{c}94.318 \\
(25.258)\end{array}$ & $\begin{array}{c}27.182 \\
(14.225)\end{array}$ & $\begin{array}{c}45.101 \\
(27.026)\end{array}$ & $\begin{array}{c}23.243 \\
(10.820)\end{array}$ & $\begin{array}{c}23.517 \\
(16.906)\end{array}$ \\
\hline 2000 & $\begin{array}{c}61.778 \\
(55.067)\end{array}$ & $\begin{array}{l}105.818 \\
(24.710)\end{array}$ & $\begin{array}{c}28.104 \\
(17.739)\end{array}$ & $\begin{array}{c}48.188 \\
(28.888)\end{array}$ & $\begin{array}{c}29.389 \\
(17.638)\end{array}$ & $\begin{array}{c}26.354 \\
(24.254)\end{array}$ \\
\hline 2001 & $\begin{array}{c}61.518 \\
(55.313) \\
\end{array}$ & $\begin{array}{r}107.163 \\
(24.441) \\
\end{array}$ & $\begin{array}{c}27.763 \\
(16.270) \\
\end{array}$ & $\begin{array}{c}47.827 \\
(29.011) \\
\end{array}$ & $\begin{array}{c}27.609 \\
(11.961) \\
\end{array}$ & $\begin{array}{c}26.252 \\
(24.026) \\
\end{array}$ \\
\hline 2002 & $\begin{array}{c}63.730 \\
(56.457) \\
\end{array}$ & $\begin{array}{l}107.159 \\
(24.470) \\
\end{array}$ & $\begin{array}{c}28.836 \\
(17.539) \\
\end{array}$ & $\begin{array}{c}48.725 \\
(28.925) \\
\end{array}$ & $\begin{array}{c}29.030 \\
(13.367) \\
\end{array}$ & $\begin{array}{c}26.152 \\
(23.295) \\
\end{array}$ \\
\hline 2003 & $\begin{array}{c}62.238 \\
(51.703) \\
\end{array}$ & $\begin{array}{l}109.240 \\
(24.447) \\
\end{array}$ & $\begin{array}{c}29.129 \\
(17.103) \\
\end{array}$ & $\begin{array}{c}49.993 \\
(29.155) \\
\end{array}$ & $\begin{array}{c}27.473 \\
(12.130) \\
\end{array}$ & $\begin{array}{c}26.081 \\
(22.188) \\
\end{array}$ \\
\hline 2004 & $\begin{array}{c}56.837 \\
(38.381)\end{array}$ & $\begin{array}{l}109.718 \\
(24.710)\end{array}$ & $\begin{array}{c}29.591 \\
(16.546)\end{array}$ & $\begin{array}{c}50.809 \\
(29.174)\end{array}$ & $\begin{array}{c}29.417 \\
(15.570)\end{array}$ & $\begin{array}{c}26.233 \\
(21.066)\end{array}$ \\
\hline 2005 & $\begin{array}{c}64.341 \\
(53.449)\end{array}$ & $\begin{array}{l}110.866 \\
(24.609)\end{array}$ & $\begin{array}{c}29.435 \\
(17.796)\end{array}$ & $\begin{array}{c}51.493 \\
(29.491)\end{array}$ & $\begin{array}{c}25.465 \\
(10.429)\end{array}$ & $\begin{array}{c}26.284 \\
(23.806)\end{array}$ \\
\hline 2006 & $\begin{array}{c}64.199 \\
(53.023) \\
\end{array}$ & $\begin{array}{l}111.873 \\
(24.734) \\
\end{array}$ & $\begin{array}{c}29.437 \\
(18.370) \\
\end{array}$ & $\begin{array}{c}52.728 \\
(29.493) \\
\end{array}$ & $\begin{array}{l}22.875 \\
(8.728) \\
\end{array}$ & $\begin{array}{c}25.911 \\
(23.475) \\
\end{array}$ \\
\hline 2007 & $\begin{array}{c}64.002 \\
(54.241)\end{array}$ & $\begin{array}{l}112.913 \\
(25.074)\end{array}$ & $\begin{array}{c}29.676 \\
(19.231)\end{array}$ & $\begin{array}{c}53.422 \\
(29.538)\end{array}$ & $\begin{array}{l}30.011 \\
(9.214)\end{array}$ & $\begin{array}{c}26.031 \\
(24.094)\end{array}$ \\
\hline 2008 & $\begin{array}{c}66.522 \\
(57.043)\end{array}$ & $\begin{array}{l}113.860 \\
(25.062)\end{array}$ & $\begin{array}{c}29.783 \\
(19.241)\end{array}$ & $\begin{array}{c}51.786 \\
(29.367)\end{array}$ & $\begin{array}{l}31.987 \\
(8.123) \\
\end{array}$ & $\begin{array}{c}26.358 \\
(24.696)\end{array}$ \\
\hline 2009 & $\begin{array}{c}65.015 \\
(53.568)\end{array}$ & $\begin{array}{l}115.348 \\
(25.013)\end{array}$ & $\begin{array}{c}29.440 \\
(18.098)\end{array}$ & $\begin{array}{c}52.648 \\
(29.139)\end{array}$ & $\begin{array}{l}29.885 \\
(7.520)\end{array}$ & $\begin{array}{c}25.900 \\
(23.366)\end{array}$ \\
\hline 2010 & $\begin{array}{c}65.454 \\
(50.904)\end{array}$ & $\begin{array}{l}116.077 \\
(24.202)\end{array}$ & $\begin{array}{c}29.952 \\
(17.951)\end{array}$ & $\begin{array}{c}53.155 \\
(29.148)\end{array}$ & $\begin{array}{c}41.967 \\
(32.761)\end{array}$ & $\begin{array}{c}26.262 \\
(22.619)\end{array}$ \\
\hline 2011 & $\begin{array}{c}66.136 \\
(51.411)\end{array}$ & $\begin{array}{l}117.662 \\
(24.392) \\
\end{array}$ & $\begin{array}{c}30.070 \\
(18.354) \\
\end{array}$ & $\begin{array}{c}54.349 \\
(29.119)\end{array}$ & $\begin{array}{c}0.000 \\
(0.000)\end{array}$ & $\begin{array}{c}26.709 \\
(23.085)\end{array}$ \\
\hline 2012 & $\begin{array}{c}64.853 \\
(50.805)\end{array}$ & $\begin{array}{l}118.534 \\
(24.529)\end{array}$ & $\begin{array}{c}29.282 \\
(17.981)\end{array}$ & $\begin{array}{c}55.571 \\
(29.094)\end{array}$ & $\begin{array}{c}0.000 \\
(0.000)\end{array}$ & $\begin{array}{c}26.241 \\
(22.878)\end{array}$ \\
\hline 2013 & $\begin{array}{c}66.030 \\
(54.038)\end{array}$ & $\begin{array}{l}119.393 \\
(24.772)\end{array}$ & $\begin{array}{c}28.869 \\
(18.168)\end{array}$ & $\begin{array}{c}56.213 \\
(28.983)\end{array}$ & $\begin{array}{c}0.000 \\
(0.000)\end{array}$ & $\begin{array}{c}26.316 \\
(23.941)\end{array}$ \\
\hline 2014 & $\begin{array}{c}66.187 \\
(55.093) \\
\end{array}$ & $\begin{array}{l}120.204 \\
(24.994) \\
\end{array}$ & $\begin{array}{c}28.566 \\
(17.812) \\
\end{array}$ & $\begin{array}{c}56.349 \\
(28.247) \\
\end{array}$ & $\begin{array}{c}0.000 \\
(0.000)\end{array}$ & $\begin{array}{c}26.599 \\
(24.388) \\
\end{array}$ \\
\hline 2015 & $\begin{array}{c}66.982 \\
(56.665)\end{array}$ & $\begin{array}{l}120.869 \\
(24.973)\end{array}$ & $\begin{array}{c}28.478 \\
(18.474)\end{array}$ & $\begin{array}{c}57.488 \\
(28.259)\end{array}$ & $\begin{array}{c}0.000 \\
(0.000)\end{array}$ & $\begin{array}{c}26.699 \\
(25.126)\end{array}$ \\
\hline
\end{tabular}

Note: Occupations that did not change their regulations status include cosmetologists, dentists, physicians, pharmacists, and lawyers. Occupations that changed their regulation status include architects, accountants, barbers, occupational therapists, physical therapists, practical nurses, registered nurses, and teachers. We manually determine whether each occupation was ever licensed by verifying licensing status through the variable occ1990. For the 1940 census data which lacks the occ1990 variable, we made a crosswalk between occ1990 and occ1950. Data are weighted using population weights. 
Appendix Table 3: Number of Observations by year and Median Duration

\begin{tabular}{|c|c|c|c|c|c|}
\hline \multirow[b]{3}{*}{ Year } & \multicolumn{3}{|c|}{13 Universally Licensed Occupations } & \multirow{3}{*}{$\begin{array}{c}\text { Never } \\
\text { Licensed } \\
\text { Occupations }\end{array}$} & \multirow{3}{*}{$\begin{array}{c}\text { Total } \\
\text { Observations }\end{array}$} \\
\hline & \multirow{2}{*}{$\begin{array}{c}\text { Unlicensed } \\
\text { Workers }\end{array}$} & \multicolumn{2}{|c|}{ Licensed Workers } & & \\
\hline & & $\begin{array}{l}\leq \text { Median } \\
\text { Duration }\end{array}$ & $\begin{array}{l}\text { > Median } \\
\text { Duration }\end{array}$ & & \\
\hline 1940 & 245,847 & 604,091 & 49,414 & $6,036,688$ & $6,936,040$ \\
\hline 1950 & 147,717 & 141,814 & 29,365 & $3,382,879$ & $3,701,775$ \\
\hline 1960 & 387,498 & 580,344 & 297,871 & $10,552,008$ & $11,817,721$ \\
\hline 1970 & 409,050 & 836,900 & 674,800 & $14,281,550$ & $16,202,300$ \\
\hline 1980 & 389,000 & $1,654,840$ & $1,334,760$ & $20,465,580$ & $23,844,180$ \\
\hline 1990 & 406,432 & $2,582,478$ & $2,392,098$ & $28,861,852$ & $34,242,860$ \\
\hline 2000 & 77,934 & $3,680,617$ & $3,104,519$ & $36,308,923$ & $43,171,993$ \\
\hline 2001 & 90,029 & $3,811,879$ & $3,067,873$ & $37,471,570$ & $44,441,351$ \\
\hline 2002 & 70,557 & $3,919,010$ & $3,158,295$ & $37,202,834$ & $44,350,696$ \\
\hline 2003 & 89,518 & $4,087,000$ & $3,388,581$ & $36,910,947$ & $44,476,046$ \\
\hline 2004 & 80,272 & $3,877,395$ & $3,653,519$ & $37,171,050$ & $44,782,236$ \\
\hline 2005 & 12,200 & $4,044,346$ & $3,815,104$ & $37,426,947$ & $45,298,597$ \\
\hline 2006 & 9,973 & $3,827,345$ & $4,162,120$ & $38,177,556$ & $46,176,994$ \\
\hline 2007 & 3,931 & $4,019,217$ & $4,305,358$ & $38,545,224$ & $46,873,730$ \\
\hline 2008 & 5,049 & $4,566,130$ & $5,205,337$ & $40,437,441$ & $50,213,957$ \\
\hline 2009 & 2,273 & $4,394,329$ & $5,375,418$ & $38,491,924$ & $48,263,944$ \\
\hline 2010 & 2,304 & $4,251,916$ & $5,371,857$ & $37,087,251$ & $46,713,328$ \\
\hline 2011 & 0 & $4,255,877$ & $5,451,546$ & $36,558,896$ & $46,266,319$ \\
\hline 2012 & 0 & $4,176,030$ & $5,719,937$ & $37,268,301$ & $47,164,268$ \\
\hline 2013 & 0 & $4,177,551$ & $5,734,232$ & $37,718,347$ & $47,630,130$ \\
\hline 2014 & 0 & $4,262,317$ & $5,816,150$ & $38,147,423$ & $48,225,890$ \\
\hline 2015 & 0 & $4,284,865$ & $5,950,806$ & $39,020,345$ & $49,256,016$ \\
\hline
\end{tabular}

Note: The 13 universally licensed occupations include architects, accountants, barbers, cosmetologists, dentists, occupational therapists, physical therapists, practical nurses, physicians, pharmacists, registered nurses, lawyers, and teachers. We manually determine whether each occupation was ever licensed by verifying licensing status through the variable occ1990. For the 1940 census data which lacks the occ1990 variable, we made a crosswalk between occ1990 and occ1950. Data are weighted using population weights. 
Appendix Table 4. Means and Standard Deviation of Licensed and Unlicensed Occupations: By Median Duration

\begin{tabular}{|c|c|c|c|c|}
\hline \multirow[b]{3}{*}{ VARIABLES } & \multicolumn{3}{|c|}{13 Universally Licensed Occupations } & \multirow{3}{*}{$\begin{array}{l}\text { Never Licensed } \\
\text { Occupations }\end{array}$} \\
\hline & \multicolumn{2}{|c|}{ Licensed Workers } & \multirow{2}{*}{ Unlicensed Workers } & \\
\hline & $<$ Median Duration & $\geq$ Median Duration & & \\
\hline White & $\begin{array}{c}0.824 \\
(0.381)\end{array}$ & $\begin{array}{c}0.793 \\
(0.405)\end{array}$ & $\begin{array}{c}0.891 \\
(0.311)\end{array}$ & $\begin{array}{c}0.794 \\
(0.405)\end{array}$ \\
\hline Male & 0.216 & 0.449 & 0.374 & 0.532 \\
\hline & & $(0.497)$ & $(0.484)$ & $(0.499)$ \\
\hline Pot. Experience & $\begin{array}{c}20.348 \\
(11.089)\end{array}$ & $\begin{array}{c}20.185 \\
(11.081)\end{array}$ & $\begin{array}{c}17.266 \\
(10.961)\end{array}$ & $\begin{array}{c}22.327 \\
(11.458)\end{array}$ \\
\hline & 15.717 & 16.303 & 15.896 & 13.450 \\
\hline Education & $(1.940)$ & $(1.974)$ & $(2.127)$ & $(2.359)$ \\
\hline Marital Status: Married & 0.629 & 0.649 & 0.643 & 0.589 \\
\hline & $(0.483)$ & $(0.477)$ & $(0.479)$ & $(0.492)$ \\
\hline Married Absent & 0.015 & 0.017 & 0.019 & 0.020 \\
\hline & $(0.123)$ & $(0.129)$ & $(0.137)$ & $(0.142)$ \\
\hline Widowed/Divorced/Seperated & 0.168 & 0.130 & 0.113 & 0.165 \\
\hline Sinole/Never Married & $\begin{array}{c}(0.373) \\
0.188\end{array}$ & $\begin{array}{c}(0.336) \\
0.204\end{array}$ & $\begin{array}{c}(0.316) \\
0.225\end{array}$ & $\begin{array}{c}(0.372) \\
0.225\end{array}$ \\
\hline single/Never Married & $(0.391)$ & $(0.403)$ & $(0.418)$ & $(0.418)$ \\
\hline Licensure & 1.000 & 1.000 & 0.000 & 0.000 \\
\hline & $\begin{array}{l}(0.000) \\
32.575\end{array}$ & $\begin{array}{l}(0.000) \\
93.862\end{array}$ & $(0.000)$ & $\begin{array}{c}(0.000) \\
0.000\end{array}$ \\
\hline Duration & $\begin{array}{c}32.575 \\
(14.616)\end{array}$ & $\begin{array}{l}93.862 \\
(26.548)\end{array}$ & $\begin{array}{c}0.000 \\
(0.000)\end{array}$ & $\begin{array}{c}0.000 \\
(0.000)\end{array}$ \\
\hline Hourly Wage (2014 CPI) & 26.132 & 45.062 & 22.356 & 25.792 \\
\hline Hourry wage (2014 CP1) & (13.135) & $(40.080)$ & (11.157) & (22.683) \\
\hline Weeks per Year & 51.268 & 51.230 & 51.231 & 51.325 \\
\hline & $(0.876)$ & $\begin{array}{l}(0.780) \\
44.955\end{array}$ & $\begin{array}{l}(1.135) \\
42538\end{array}$ & $\begin{array}{l}(0.814) \\
42977\end{array}$ \\
\hline Hours per Week & $\begin{array}{l}42.256 \\
(7.446)\end{array}$ & & $\begin{array}{l}42.538 \\
(7.169)\end{array}$ & $\begin{array}{l}42.977 \\
(7.681)\end{array}$ \\
\hline Hours per Year & 2166.376 & 2303.258 & 2179.171 & 2206.053 \\
\hline Hours per year & (383.394) & (514.367) & (369.992) & (397.182) \\
\hline Accountants & 0.023 & 0.329 & 0.004 & 0.000 \\
\hline & $(0.148)$ & $(0.470)$ & $(0.060)$ & $(0.000)$ \\
\hline Architects & $\begin{array}{c}0.002 \\
(0.040)\end{array}$ & $\begin{array}{c}0.028 \\
(0.165)\end{array}$ & $\begin{array}{l}0.0003 \\
(0.019)\end{array}$ & $\begin{array}{c}0.000 \\
(0.000)\end{array}$ \\
\hline Barbers & 0.002 & 0.005 & 0.002 & 0.000 \\
\hline Barbers & $(0.043)$ & $(0.073)$ & $(0.047)$ & $(0.000)$ \\
\hline Cosmetologists & 0.006 & 0.051 & 0.000 & 0.000 \\
\hline cosmetologists & $(0.075)$ & $(0.219)$ & $(0.000)$ & $(0.000)$ \\
\hline Lawyers & 0.001 & 0.150 & 0.000 & 0.000 \\
\hline Lawyers & $(0.028)$ & $(0.357)$ & $(0.000)$ & $(0.000)$ \\
\hline Occupational Therapists & 0.011 & 0.000 & 0.026 & 0.000 \\
\hline & $(0.106)$ & $(0.000)$ & $(0.159)$ & $(0.000)$ \\
\hline Physical Therapists & 0.023 & 0.006 & 0.0001 & 0.000 \\
\hline & $(0.151)$ & $(0.074)$ & $(0.010)$ & $(0.000)$ \\
\hline Practical Nurses & $\begin{array}{c}0.060 \\
(0.237)\end{array}$ & $\begin{array}{c}0.011 \\
(0.106)\end{array}$ & $\begin{array}{c}0.012 \\
(0.110)\end{array}$ & $\begin{array}{c}0.000 \\
(0.000)\end{array}$ \\
\hline Registered Nurses & 0.309 & 0.120 & 0.106 & 0.000 \\
\hline & $(0.462)$ & $(0.325)$ & $(0.308)$ & $(0.000)$ \\
\hline Dentists & 0.0001 & 0.020 & 0.000 & 0.000 \\
\hline & $(0.011)$ & $(0.139)$ & $(0.000)$ & $(0.000)$ \\
\hline Physicians & $\begin{array}{l}0.0003 \\
(0.019)\end{array}$ & $\begin{array}{c}0.135 \\
(0.341)\end{array}$ & $\begin{array}{c}0.000 \\
(0.000)\end{array}$ & $\begin{array}{c}0.000 \\
(0.000)\end{array}$ \\
\hline Pharmacists & 0.0005 & 0.041 & 0.000 & 0.000 \\
\hline Pharmacists & $(0.022)$ & (0.199) & $(0.000)$ & $(0.000)$ \\
\hline Teachers & $\begin{array}{c}0.563 \\
(0.496)\end{array}$ & $\begin{array}{c}0.104 \\
(0.305)\end{array}$ & $\begin{array}{c}0.849 \\
(0.358)\end{array}$ & $\begin{array}{c}0.000 \\
(0.000)\end{array}$ \\
\hline Observations & 963,756 & 971,796 & 61,490 & $9,243,914$ \\
\hline Weighted Observations & $7,203,6291$ & $7,8058,960$ & $2,429,584$ & $687,525,536$ \\
\hline
\end{tabular}

Note: The 13 universally licensed occupations include architects, accountants, barbers, cosmetologists, dentists, occupational therapists, physical therapists, practical nurses, physicians, pharmacists, registered nurses, lawyers, and teachers. We manually determine whether each occupation was ever licensed by verifying licensing status through the variable occ1990. For the 1940 census data which lacks the occ1990 variable, we made a crosswalk between occ1990 and occ1950. Data are weighted using population weights. 
Appendix Table 5: Mean of Hourly Wage and Duration by year and Median Duration

\begin{tabular}{|c|c|c|c|c|c|c|}
\hline \multirow[b]{3}{*}{ Year } & \multicolumn{5}{|c|}{13 Universally Licensed Occupations } & \multirow{3}{*}{$\begin{array}{c}\text { Never } \\
\text { Licensed } \\
\text { Occupations }\end{array}$} \\
\hline & \multicolumn{2}{|c|}{ Licensed $<$ Median Duration } & \multicolumn{2}{|c|}{ Licensed $\geq$ Median Duration } & \multirow{2}{*}{$\begin{array}{c}\text { Unlicensed } \\
\text { Wage }\end{array}$} & \\
\hline & Wage & Duration & Wage & Duration & & \\
\hline 1940 & $\begin{array}{l}13.106 \\
(7.641)\end{array}$ & $\begin{array}{l}32.410 \\
(7.975)\end{array}$ & $\begin{array}{c}21.812 \\
(11.290)\end{array}$ & $\begin{array}{c}65.222 \\
(16.764)\end{array}$ & $\begin{array}{l}13.597 \\
(8.020)\end{array}$ & $\begin{array}{l}11.969 \\
(6.316)\end{array}$ \\
\hline 1950 & $\begin{array}{l}18.736 \\
(8.375)\end{array}$ & $\begin{array}{c}34.654 \\
(16.123)\end{array}$ & $\begin{array}{c}19.972 \\
(11.107)\end{array}$ & $\begin{array}{c}68.585 \\
(15.956)\end{array}$ & $\begin{array}{l}14.150 \\
(5.644)\end{array}$ & $\begin{array}{l}13.781 \\
(6.489)\end{array}$ \\
\hline 1960 & $\begin{array}{c}22.277 \\
(11.463)\end{array}$ & $\begin{array}{c}28.369 \\
(18.339)\end{array}$ & $\begin{array}{c}30.962 \\
(17.751)\end{array}$ & $\begin{array}{c}68.248 \\
(15.345)\end{array}$ & $\begin{array}{l}19.886 \\
(7.612)\end{array}$ & $\begin{array}{l}20.120 \\
(9.709)\end{array}$ \\
\hline 1970 & $\begin{array}{c}25.716 \\
(11.513)\end{array}$ & $\begin{array}{c}22.100 \\
(15.831)\end{array}$ & $\begin{array}{c}38.780 \\
(23.535)\end{array}$ & $\begin{array}{c}71.674 \\
(15.343)\end{array}$ & $\begin{array}{c}25.550 \\
(10.029)\end{array}$ & $\begin{array}{c}25.496 \\
(14.325)\end{array}$ \\
\hline 1980 & $\begin{array}{l}23.515 \\
(9.807)\end{array}$ & $\begin{array}{c}22.068 \\
(13.329)\end{array}$ & $\begin{array}{c}37.564 \\
(23.575)\end{array}$ & $\begin{array}{c}80.981 \\
(17.083)\end{array}$ & $\begin{array}{l}22.237 \\
(8.785)\end{array}$ & $\begin{array}{c}23.984 \\
(13.584)\end{array}$ \\
\hline 1990 & $\begin{array}{c}25.933 \\
(12.056)\end{array}$ & $\begin{array}{c}28.355 \\
(12.697)\end{array}$ & $\begin{array}{c}40.884 \\
(34.267)\end{array}$ & $\begin{array}{c}88.474 \\
(18.930)\end{array}$ & $\begin{array}{c}23.243 \\
(10.820)\end{array}$ & $\begin{array}{c}23.517 \\
(16.906)\end{array}$ \\
\hline 2000 & $\begin{array}{c}26.340 \\
(14.137)\end{array}$ & $\begin{array}{c}31.538 \\
(15.240)\end{array}$ & $\begin{array}{c}46.289 \\
(44.240)\end{array}$ & $\begin{array}{c}95.470 \\
(21.552)\end{array}$ & $\begin{array}{c}29.389 \\
(17.638)\end{array}$ & $\begin{array}{c}26.354 \\
(24.254)\end{array}$ \\
\hline 2001 & $\begin{array}{c}25.962 \\
(12.267)\end{array}$ & $\begin{array}{c}31.777 \\
(15.510)\end{array}$ & $\begin{array}{c}46.599 \\
(44.524)\end{array}$ & $\begin{array}{c}96.948 \\
(21.604)\end{array}$ & $\begin{array}{c}27.609 \\
(11.961)\end{array}$ & $\begin{array}{c}26.252 \\
(24.026)\end{array}$ \\
\hline 2002 & $\begin{array}{c}26.861 \\
(13.653)\end{array}$ & $\begin{array}{c}32.654 \\
(15.448)\end{array}$ & $\begin{array}{c}48.120 \\
(45.364)\end{array}$ & $\begin{array}{c}96.857 \\
(21.774)\end{array}$ & $\begin{array}{c}29.030 \\
(13.367)\end{array}$ & $\begin{array}{c}26.152 \\
(23.295)\end{array}$ \\
\hline 2003 & $\begin{array}{c}27.292 \\
(13.971) \\
\end{array}$ & $\begin{array}{c}33.422 \\
(15.593)\end{array}$ & $\begin{array}{c}47.006 \\
(41.604)\end{array}$ & $\begin{array}{c}98.006 \\
(22.058)\end{array}$ & $\begin{array}{l}27.473 \\
(12.130)\end{array}$ & $\begin{array}{c}26.081 \\
(22.188)\end{array}$ \\
\hline 2004 & $\begin{array}{c}27.354 \\
(13.163)\end{array}$ & $\begin{array}{c}33.074 \\
(15.023)\end{array}$ & $\begin{array}{c}44.364 \\
(32.256)\end{array}$ & $\begin{array}{c}96.441 \\
(23.846)\end{array}$ & $\begin{array}{c}29.417 \\
(15.570)\end{array}$ & $\begin{array}{c}26.233 \\
(21.066)\end{array}$ \\
\hline 2005 & $\begin{array}{c}27.388 \\
(13.695)\end{array}$ & $\begin{array}{c}33.671 \\
(15.574)\end{array}$ & $\begin{array}{c}47.552 \\
(42.871)\end{array}$ & $\begin{array}{c}97.511 \\
(23.875)\end{array}$ & $\begin{array}{c}25.465 \\
(10.429)\end{array}$ & $\begin{array}{c}26.284 \\
(23.806)\end{array}$ \\
\hline 2006 & $\begin{array}{c}26.921 \\
(13.501) \\
\end{array}$ & $\begin{array}{c}33.272 \\
(14.966) \\
\end{array}$ & $\begin{array}{c}46.341 \\
(41.642) \\
\end{array}$ & $\begin{array}{c}95.442 \\
(25.516) \\
\end{array}$ & $\begin{array}{r}22.875 \\
(8.728) \\
\end{array}$ & $\begin{array}{c}25.911 \\
(23.475) \\
\end{array}$ \\
\hline 2007 & $\begin{array}{c}26.996 \\
(13.984)\end{array}$ & $\begin{array}{c}34.076 \\
(15.071)\end{array}$ & $\begin{array}{c}46.569 \\
(42.578)\end{array}$ & $\begin{array}{c}96.424 \\
(25.650)\end{array}$ & $\begin{array}{l}30.011 \\
(9.214)\end{array}$ & $\begin{array}{c}26.031 \\
(24.094)\end{array}$ \\
\hline 2008 & $\begin{array}{c}26.876 \\
(13.523)\end{array}$ & $\begin{array}{c}31.528 \\
(14.501)\end{array}$ & $\begin{array}{c}45.818 \\
(42.707)\end{array}$ & $\begin{array}{c}92.341 \\
(27.532)\end{array}$ & $\begin{array}{l}31.987 \\
(8.123)\end{array}$ & $\begin{array}{c}26.358 \\
(24.696)\end{array}$ \\
\hline 2009 & $\begin{array}{c}26.460 \\
(12.739)\end{array}$ & $\begin{array}{c}31.782 \\
(14.051)\end{array}$ & $\begin{array}{c}44.634 \\
(39.875)\end{array}$ & $\begin{array}{c}92.191 \\
(28.142)\end{array}$ & $\begin{array}{l}29.885 \\
(7.520)\end{array}$ & $\begin{array}{c}25.900 \\
(23.366)\end{array}$ \\
\hline 2010 & $\begin{array}{c}26.658 \\
(12.760) \\
\end{array}$ & $\begin{array}{c}31.855 \\
(13.748)\end{array}$ & $\begin{array}{c}44.994 \\
(38.074)\end{array}$ & $\begin{array}{c}92.052 \\
(28.189)\end{array}$ & $\begin{array}{c}41.967 \\
(32.761)\end{array}$ & $\begin{array}{c}26.262 \\
(22.619)\end{array}$ \\
\hline 2011 & $\begin{array}{c}26.860 \\
(13.402)\end{array}$ & $\begin{array}{c}32.971 \\
(13.707)\end{array}$ & $\begin{array}{c}45.324 \\
(38.651)\end{array}$ & $\begin{array}{c}93.418 \\
(28.417)\end{array}$ & $\begin{array}{c}0.000 \\
(0.000)\end{array}$ & $\begin{array}{c}26.709 \\
(23.085)\end{array}$ \\
\hline 2012 & $\begin{array}{c}25.694 \\
(12.375)\end{array}$ & $\begin{array}{c}33.471 \\
(13.447)\end{array}$ & $\begin{array}{c}44.153 \\
(37.820)\end{array}$ & $\begin{array}{c}93.390 \\
(28.750)\end{array}$ & $\begin{array}{c}0.000 \\
(0.000)\end{array}$ & $\begin{array}{c}26.241 \\
(22.878)\end{array}$ \\
\hline 2013 & $\begin{array}{c}25.128 \\
(12.853)\end{array}$ & $\begin{array}{c}34.264 \\
(13.329)\end{array}$ & $\begin{array}{c}44.610 \\
(39.788)\end{array}$ & $\begin{array}{l}94.3322 \\
(28.938)\end{array}$ & $\begin{array}{c}0.000 \\
(0.000)\end{array}$ & $\begin{array}{c}26.316 \\
(23.941)\end{array}$ \\
\hline 2014 & $\begin{array}{c}24.835 \\
(12.607)\end{array}$ & $\begin{array}{c}35.118 \\
(13.185)\end{array}$ & $\begin{array}{c}44.158 \\
(39.908)\end{array}$ & $\begin{array}{c}93.731 \\
(29.357)\end{array}$ & $\begin{array}{c}0.000 \\
(0.000)\end{array}$ & $\begin{array}{c}26.599 \\
(24.388)\end{array}$ \\
\hline 2015 & $\begin{array}{c}24.660 \\
(12.917)\end{array}$ & $\begin{array}{c}36.155 \\
(13.114)\end{array}$ & $\begin{array}{c}44.578 \\
(41.307)\end{array}$ & $\begin{array}{c}94.826 \\
(29.329)\end{array}$ & $\begin{array}{c}0.000 \\
(0.000)\end{array}$ & $\begin{array}{c}26.699 \\
(25.126)\end{array}$ \\
\hline
\end{tabular}

Note: The 13 universally licensed occupations include architects, accountants, barbers, cosmetologists, dentists, occupational therapists, physical therapists, practical nurses, physicians, pharmacists, registered nurses, lawyers, and teachers. We manually determine whether each occupation was ever licensed by verifying licensing status through the variable occ1990. For the 1940 census data which lacks the occ1990 variable, we made a crosswalk between occ1990 and occ1950. Data are weighted using population weights. 
Appendix Table 6. The Estimated Impact of Occupational Licensing on Hourly Wage

Panel A.13 Universally Licensed occupations

\begin{tabular}{|c|c|c|c|c|c|c|c|}
\hline \multirow{2}{*}{ Control Group } & (1) & (2) & (3) & (4) & (5) & (6) & (7) \\
\hline & \multicolumn{5}{|c|}{$\begin{array}{l}\text { Relative to Individuals in Never Licensed Occupations Throughout } \\
\text { Our period of Analysis }\end{array}$} & \multicolumn{2}{|c|}{$\begin{array}{c}\text { Relative to Unlicensed } \\
\text { Workers in Universally } \\
\text { Licensed Occupations } \\
\text { Prior to States Passing } \\
\text { Licensing Statutes }\end{array}$} \\
\hline Leads and Lags: & & & & & & & \\
\hline Licensure $_{t+6}$ & $\begin{array}{c}-0.222 * * * \\
(0.039)\end{array}$ & $\begin{array}{c}0.008 \\
(0.023)\end{array}$ & $\begin{array}{c}0.015 \\
(0.022)\end{array}$ & $\begin{array}{c}0.015 \\
(0.022)\end{array}$ & $\begin{array}{c}0.014 \\
(0.021)\end{array}$ & $\begin{array}{l}0.076^{*} \\
(0.043)\end{array}$ & $\begin{array}{c}0.003 \\
(0.024)\end{array}$ \\
\hline Licensure $_{t+5}$ & $\begin{array}{c}-0.212 * * * \\
(0.023)\end{array}$ & $\begin{array}{c}0.046 \\
(0.029)\end{array}$ & $\begin{array}{c}0.042 \\
(0.030)\end{array}$ & $\begin{array}{c}0.039 \\
(0.030)\end{array}$ & $\begin{array}{c}0.032 \\
(0.032)\end{array}$ & $\begin{array}{l}-0.000 \\
(0.029)\end{array}$ & $\begin{array}{l}-0.042 * \\
(0.022)\end{array}$ \\
\hline Licensure $_{t+4}$ & $\begin{array}{c}-0.199 * * * \\
(0.035)\end{array}$ & $\begin{array}{c}0.062 \\
(0.038)\end{array}$ & $\begin{array}{c}0.061 \\
(0.041)\end{array}$ & $\begin{array}{c}0.059 \\
(0.041)\end{array}$ & $\begin{array}{c}0.058 \\
(0.043)\end{array}$ & $\begin{array}{c}0.018 \\
(0.034)\end{array}$ & $\begin{array}{l}-0.037 \\
(0.031)\end{array}$ \\
\hline Licensure $_{t+3}$ & $\begin{array}{c}-0.186 * * * \\
(0.027)\end{array}$ & $\begin{array}{c}0.011 \\
(0.040)\end{array}$ & $\begin{array}{c}0.011 \\
(0.042)\end{array}$ & $\begin{array}{c}0.010 \\
(0.042)\end{array}$ & $\begin{array}{c}0.013 \\
(0.043)\end{array}$ & $\begin{array}{c}0.086^{* * *} \\
(0.030)\end{array}$ & $\begin{array}{l}-0.022 \\
(0.028)\end{array}$ \\
\hline Licensure $_{t+2}$ & $\begin{array}{c}-0.137 * * * \\
(0.030)\end{array}$ & $\begin{array}{c}0.069 \\
(0.044)\end{array}$ & $\begin{array}{c}0.059 \\
(0.045)\end{array}$ & $\begin{array}{c}0.056 \\
(0.046)\end{array}$ & $\begin{array}{c}0.047 \\
(0.048)\end{array}$ & $\begin{array}{c}0.056 \\
(0.036)\end{array}$ & $\begin{array}{c}-0.080^{* *} \\
(0.035)\end{array}$ \\
\hline Licensure $_{t+1}$ & $\begin{array}{c}-0.146^{* * *} \\
(0.024)\end{array}$ & $\begin{array}{l}-0.018 \\
(0.063)\end{array}$ & $\begin{array}{l}-0.028 \\
(0.067)\end{array}$ & $\begin{array}{l}-0.030 \\
(0.067)\end{array}$ & $\begin{array}{l}-0.036 \\
(0.069)\end{array}$ & $\begin{array}{c}0.079 * * * \\
(0.029)\end{array}$ & $\begin{array}{c}-0.113^{* *} \\
(0.047)\end{array}$ \\
\hline Licensure $_{t+0}$ & $\begin{array}{c}-0.216^{* * *} \\
(0.035)\end{array}$ & $\begin{array}{l}0.055^{*} \\
(0.033)\end{array}$ & $\begin{array}{l}0.060^{*} \\
(0.031)\end{array}$ & $\begin{array}{l}0.059^{*} \\
(0.031)\end{array}$ & $\begin{array}{l}0.055^{*} \\
(0.031)\end{array}$ & $\begin{array}{l}-0.013 \\
(0.032)\end{array}$ & $\begin{array}{c}-0.061 * * * \\
(0.023)\end{array}$ \\
\hline Licensure $_{t-1}$ & $\begin{array}{c}-0.157 * * * \\
(0.030)\end{array}$ & $\begin{array}{c}0.035 \\
(0.024)\end{array}$ & $\begin{array}{c}0.032 \\
(0.024)\end{array}$ & $\begin{array}{c}0.029 \\
(0.024)\end{array}$ & $\begin{array}{c}0.022 \\
(0.025)\end{array}$ & $\begin{array}{l}0.067 * * \\
(0.031)\end{array}$ & $\begin{array}{c}-0.064 * * * \\
(0.022)\end{array}$ \\
\hline Licensure $_{t-2}$ & $\begin{array}{c}-0.229 * * * \\
(0.022)\end{array}$ & $\begin{array}{l}0.039 * \\
(0.021)\end{array}$ & $\begin{array}{c}0.044^{* *} \\
(0.020)\end{array}$ & $\begin{array}{c}0.043^{* *} \\
(0.020)\end{array}$ & $\begin{array}{c}0.042 * * \\
(0.019)\end{array}$ & $\begin{array}{l}-0.016 \\
(0.023)\end{array}$ & $\begin{array}{c}-0.058 * * * \\
(0.018)\end{array}$ \\
\hline Licensure $_{t-3}$ & $\begin{array}{c}-0.221 * * * \\
(0.020)\end{array}$ & $\begin{array}{c}0.040 * * \\
(0.018)\end{array}$ & $\begin{array}{c}0.041^{* *} \\
(0.018)\end{array}$ & $\begin{array}{c}0.039 * * \\
(0.018)\end{array}$ & $\begin{array}{l}0.033^{*} \\
(0.018)\end{array}$ & $\begin{array}{l}-0.033^{*} \\
(0.018)\end{array}$ & $\begin{array}{c}-0.098 * * * \\
(0.016)\end{array}$ \\
\hline Licensure $_{t-4}$ & $\begin{array}{c}-0.200^{* * *} \\
(0.022)\end{array}$ & $\begin{array}{c}0.077 * * * \\
(0.020)\end{array}$ & $\begin{array}{c}0.079 * * * \\
(0.020)\end{array}$ & $\begin{array}{c}0.077 * * * \\
(0.020)\end{array}$ & $\begin{array}{c}0.073 * * * \\
(0.020)\end{array}$ & $\begin{array}{l}-0.009 \\
(0.024)\end{array}$ & $\begin{array}{c}-0.060 * * * \\
(0.018)\end{array}$ \\
\hline Licensure $_{t-5}$ & $\begin{array}{c}-0.200^{* * * *} \\
(0.019)\end{array}$ & $\begin{array}{c}0.066^{* * *} \\
(0.018)\end{array}$ & $\begin{array}{c}0.065^{* * *} \\
(0.018)\end{array}$ & $\begin{array}{c}0.062^{* * *} \\
(0.019)\end{array}$ & $\begin{array}{c}0.056 * * * \\
(0.020)\end{array}$ & $\begin{array}{l}-0.018 \\
(0.022)\end{array}$ & $\begin{array}{c}-0.085^{* * *} \\
(0.018)\end{array}$ \\
\hline Licensure $_{t-6}$ & $\begin{array}{c}-0.192^{* * *} \\
(0.019)\end{array}$ & $\begin{array}{c}0.083^{* * *} \\
(0.018)\end{array}$ & $\begin{array}{c}0.082 * * * \\
(0.019)\end{array}$ & $\begin{array}{c}0.079 * * * \\
(0.019)\end{array}$ & $\begin{array}{c}0.072 * * * \\
(0.020)\end{array}$ & $\begin{array}{l}-0.018 \\
(0.023)\end{array}$ & $\begin{array}{c}-0.077 * * * \\
(0.019)\end{array}$ \\
\hline Licensure $_{t-7}$ & $\begin{array}{c}-0.185^{* * *} \\
(0.018)\end{array}$ & $\begin{array}{c}0.061^{* * *} \\
(0.016)\end{array}$ & $\begin{array}{c}0.058^{* * *} \\
(0.017)\end{array}$ & $\begin{array}{c}0.056^{* * *} \\
(0.017)\end{array}$ & $\begin{array}{c}0.049 * * * \\
(0.018)\end{array}$ & $\begin{array}{c}0.014 \\
(0.019)\end{array}$ & $\begin{array}{c}-0.075^{* * *} \\
(0.015)\end{array}$ \\
\hline Licensure $_{t-8}$ & $\begin{array}{c}-0.204^{* * *} \\
(0.020)\end{array}$ & $\begin{array}{c}0.063^{* * *} * \\
(0.017)\end{array}$ & $\begin{array}{c}0.061 * * * \\
(0.017)\end{array}$ & $\begin{array}{c}0.058 * * * \\
(0.017)\end{array}$ & $\begin{array}{c}0.051 * * * \\
(0.017)\end{array}$ & $\begin{array}{l}-0.040 * \\
(0.021)\end{array}$ & $\begin{array}{c}-0.113^{* * *} \\
(0.015)\end{array}$ \\
\hline Licensure $_{t-9}$ & $\begin{array}{c}-0.198^{* * *} \\
(0.020)\end{array}$ & $\begin{array}{c}0.036^{* *} \\
(0.017)\end{array}$ & $\begin{array}{l}0.033^{*} \\
(0.018)\end{array}$ & $\begin{array}{l}0.030^{*} \\
(0.018)\end{array}$ & $\begin{array}{c}0.022 \\
(0.018)\end{array}$ & $\begin{array}{l}-0.017 \\
(0.020)\end{array}$ & $\begin{array}{c}-0.125 * * * \\
(0.016)\end{array}$ \\
\hline Licensure $_{t-10}$ & $\begin{array}{c}-0.202^{* * *} \\
(0.018)\end{array}$ & $\begin{array}{c}0.077 * * * \\
(0.016)\end{array}$ & $\begin{array}{c}0.074 * * * \\
(0.016)\end{array}$ & $\begin{array}{c}0.072 * * * \\
(0.017)\end{array}$ & $\begin{array}{c}0.062 * * * \\
(0.017)\end{array}$ & $\begin{array}{l}-0.039^{*} \\
(0.021)\end{array}$ & $\begin{array}{c}-0.111 * * * \\
(0.016)\end{array}$ \\
\hline Licensure $_{t-11}$ & $\begin{array}{c}-0.176^{* * * *} \\
(0.021)\end{array}$ & $\begin{array}{c}0.051^{* * *} \\
(0.016)\end{array}$ & $\begin{array}{c}0.047 * * * \\
(0.016)\end{array}$ & $\begin{array}{c}0.043 * * * \\
(0.016)\end{array}$ & $\begin{array}{c}0.035 * * \\
(0.017)\end{array}$ & $\begin{array}{c}0.006 \\
(0.021)\end{array}$ & $\begin{array}{c}-0.114 * * * \\
(0.017)\end{array}$ \\
\hline Licensure $_{t-12}$ & $\begin{array}{c}-0.202^{* * *} \\
(0.018)\end{array}$ & $\begin{array}{c}0.068 * * * \\
(0.017)\end{array}$ & $\begin{array}{c}0.066^{* * *} \\
(0.017)\end{array}$ & $\begin{array}{c}0.064 * * * \\
(0.017)\end{array}$ & $\begin{array}{c}0.053 * * * \\
(0.017)\end{array}$ & $\begin{array}{l}-0.029 \\
(0.024)\end{array}$ & $\begin{array}{c}-0.111 * * * \\
(0.017)\end{array}$ \\
\hline Licensure $_{t-13}$ & $\begin{array}{c}-0.202^{* * *} \\
(0.017)\end{array}$ & $\begin{array}{c}0.054^{* * *} * \\
(0.020)\end{array}$ & $\begin{array}{c}0.053^{* * *} \\
(0.019)\end{array}$ & $\begin{array}{c}0.050 * * \\
(0.020)\end{array}$ & $\begin{array}{c}0.040^{* *} \\
(0.020)\end{array}$ & $\begin{array}{l}-0.030 \\
(0.023)\end{array}$ & $\begin{array}{c}-0.128 * * * \\
(0.019)\end{array}$ \\
\hline Licensure $_{t-14}$ & $\begin{array}{c}-0.216^{* * *} \\
(0.017)\end{array}$ & $\begin{array}{c}0.064 * * * \\
(0.019)\end{array}$ & $\begin{array}{c}0.063 * * * \\
(0.019)\end{array}$ & $\begin{array}{c}0.061^{* * *} \\
(0.019)\end{array}$ & $\begin{array}{c}0.051^{* * *} \\
(0.019)\end{array}$ & $\begin{array}{l}-0.034 \\
(0.026)\end{array}$ & $\begin{array}{c}-0.113^{* * *} \\
(0.019)\end{array}$ \\
\hline Licensure $_{t-15}$ & $\begin{array}{c}-0.220^{* * *} \\
(0.016)\end{array}$ & $\begin{array}{c}0.042^{* *} \\
(0.017)\end{array}$ & $\begin{array}{c}0.042 * * \\
(0.017)\end{array}$ & $\begin{array}{c}0.039 * * \\
(0.018)\end{array}$ & $\begin{array}{c}0.029 \\
(0.018)\end{array}$ & $\begin{array}{l}-0.037 * \\
(0.022)\end{array}$ & $\begin{array}{c}-0.133 * * * \\
(0.018)\end{array}$ \\
\hline
\end{tabular}




\begin{tabular}{|c|c|c|c|c|c|c|c|}
\hline Licensure $_{t-16}$ & $\begin{array}{c}-0.221^{* * *} \\
(0.018)\end{array}$ & $\begin{array}{c}0.047 * * * \\
(0.018)\end{array}$ & $\begin{array}{c}0.044^{* *} \\
(0.018)\end{array}$ & $\begin{array}{c}0.041^{* *} \\
(0.018)\end{array}$ & $\begin{array}{c}0.030 \\
(0.019)\end{array}$ & $\begin{array}{l}-0.042 * \\
(0.023)\end{array}$ & $\begin{array}{c}-0.137 * * * \\
(0.018)\end{array}$ \\
\hline Licensure $_{t-17}$ & $\begin{array}{c}-0.197 * * * \\
(0.022)\end{array}$ & $\begin{array}{c}0.037 * * \\
(0.016)\end{array}$ & $\begin{array}{c}0.034^{* *} \\
(0.016)\end{array}$ & $\begin{array}{l}0.031^{*} \\
(0.017)\end{array}$ & $\begin{array}{c}0.021 \\
(0.017)\end{array}$ & $\begin{array}{c}0.010 \\
(0.022)\end{array}$ & $\begin{array}{c}-0.118^{* * *} \\
(0.016)\end{array}$ \\
\hline Licensure $_{t-18}$ & $\begin{array}{c}-0.210^{* * *} \\
(0.024)\end{array}$ & $\begin{array}{l}0.038^{*} \\
(0.020)\end{array}$ & $\begin{array}{c}0.032 \\
(0.019)\end{array}$ & $\begin{array}{c}0.029 \\
(0.020)\end{array}$ & $\begin{array}{c}0.016 \\
(0.020)\end{array}$ & $\begin{array}{l}-0.031 \\
(0.027)\end{array}$ & $\begin{array}{c}-0.149 * * * \\
(0.020)\end{array}$ \\
\hline Licensure $_{t-19}$ & $\begin{array}{c}-0.151^{* * *} \\
(0.040)\end{array}$ & $\begin{array}{c}0.001 \\
(0.026)\end{array}$ & $\begin{array}{c}-0.004 \\
(0.027)\end{array}$ & $\begin{array}{c}-0.010 \\
(0.027)\end{array}$ & $\begin{array}{c}-0.021 \\
(0.027)\end{array}$ & $\begin{array}{c}0.058 \\
(0.042)\end{array}$ & $\begin{array}{c}-0.148^{* * *} \\
(0.025)\end{array}$ \\
\hline Licensure $_{t-20}$ & $\begin{array}{c}-0.211 * * * \\
(0.021)\end{array}$ & $\begin{array}{c}0.051^{* *} \\
(0.024)\end{array}$ & $\begin{array}{l}0.043^{*} \\
(0.023)\end{array}$ & $\begin{array}{l}0.040^{*} \\
(0.023)\end{array}$ & $\begin{array}{c}0.026 \\
(0.023)\end{array}$ & $\begin{array}{l}-0.018 \\
(0.031)\end{array}$ & $\begin{array}{c}-0.130 * * * \\
(0.023)\end{array}$ \\
\hline Licensure $_{t-21}$ & $\begin{array}{c}-0.082^{* *} \\
(0.037)\end{array}$ & $\begin{array}{c}0.065 * * * \\
(0.019)\end{array}$ & $\begin{array}{c}0.064 * * * \\
(0.019)\end{array}$ & $\begin{array}{c}0.060 * * * \\
(0.019)\end{array}$ & $\begin{array}{c}0.050 * * * \\
(0.019)\end{array}$ & $\begin{array}{c}0.137 * * * \\
(0.038)\end{array}$ & $\begin{array}{c}-0.080 * * * \\
(0.023)\end{array}$ \\
\hline Licensure $_{t-22}$ & $\begin{array}{c}-0.167 * * * \\
(0.019)\end{array}$ & $\begin{array}{c}0.073 * * * \\
(0.021)\end{array}$ & $\begin{array}{c}0.071 * * * \\
(0.021)\end{array}$ & $\begin{array}{c}0.067 * * * \\
(0.021)\end{array}$ & $\begin{array}{c}0.059 * * * \\
(0.021)\end{array}$ & $\begin{array}{l}0.052 * \\
(0.031)\end{array}$ & $\begin{array}{c}-0.092 * * * \\
(0.021)\end{array}$ \\
\hline Licensure $_{t-23}$ & $\begin{array}{c}-0.127 * * * \\
(0.020)\end{array}$ & $\begin{array}{c}0.076 * * * \\
(0.022)\end{array}$ & $\begin{array}{c}0.085 * * * \\
(0.020)\end{array}$ & $\begin{array}{c}0.072 * * * \\
(0.021)\end{array}$ & $\begin{array}{c}0.069 * * * \\
(0.021)\end{array}$ & $\begin{array}{c}0.094 * * * \\
(0.030)\end{array}$ & $\begin{array}{c}-0.074 * * * \\
(0.021)\end{array}$ \\
\hline Licensure $_{t-24}$ & $\begin{array}{c}-0.163 * * * \\
(0.018)\end{array}$ & $\begin{array}{c}0.097 * * * \\
(0.021)\end{array}$ & $\begin{array}{c}0.091 * * * \\
(0.020)\end{array}$ & $\begin{array}{c}0.089 * * * \\
(0.021)\end{array}$ & $\begin{array}{c}0.079 * * * \\
(0.021)\end{array}$ & $\begin{array}{c}0.054 \\
(0.033)\end{array}$ & $\begin{array}{c}-0.076^{* * * *} \\
(0.022)\end{array}$ \\
\hline Licensure $_{t-25}$ & $\begin{array}{c}-0.134^{* * *} \\
(0.018)\end{array}$ & $\begin{array}{c}0.090 * * * \\
(0.021)\end{array}$ & $\begin{array}{c}0.092 * * * \\
(0.020)\end{array}$ & $\begin{array}{c}0.084 * * * \\
(0.021)\end{array}$ & $\begin{array}{c}0.077 * * * \\
(0.021)\end{array}$ & $\begin{array}{c}0.085 * * * \\
(0.031)\end{array}$ & $\begin{array}{c}-0.075^{* * *} \\
(0.021)\end{array}$ \\
\hline Licensure $_{t-26}$ & $\begin{array}{c}-0.163^{* * *} \\
(0.020)\end{array}$ & $\begin{array}{c}0.079 * * * \\
(0.022)\end{array}$ & $\begin{array}{c}0.072 * * * \\
(0.021)\end{array}$ & $\begin{array}{c}0.069 * * * \\
(0.021)\end{array}$ & $\begin{array}{c}0.059 * * * \\
(0.021)\end{array}$ & $\begin{array}{l}0.056^{*} \\
(0.033)\end{array}$ & $\begin{array}{c}-0.099 * * * \\
(0.022)\end{array}$ \\
\hline Licensure $_{t-27}$ & $\begin{array}{c}-0.128 * * * \\
(0.022)\end{array}$ & $\begin{array}{c}0.068 * * * \\
(0.020)\end{array}$ & $\begin{array}{c}0.064 * * * \\
(0.019)\end{array}$ & $\begin{array}{c}0.062 * * * \\
(0.020)\end{array}$ & $\begin{array}{c}0.053 * * * \\
(0.019)\end{array}$ & $\begin{array}{c}0.106 * * * \\
(0.032)\end{array}$ & $\begin{array}{c}-0.086 * * * \\
(0.020)\end{array}$ \\
\hline Licensure $_{t-28}$ & $\begin{array}{c}-0.121^{* * *} \\
(0.026)\end{array}$ & $\begin{array}{c}0.079 * * * \\
(0.022)\end{array}$ & $\begin{array}{c}0.078^{* * *} \\
(0.021)\end{array}$ & $\begin{array}{c}0.075 * * * \\
(0.021)\end{array}$ & $\begin{array}{c}0.066 * * * \\
(0.021)\end{array}$ & $\begin{array}{c}0.092 * * * \\
(0.034)\end{array}$ & $\begin{array}{c}-0.104^{* * *} \\
(0.022)\end{array}$ \\
\hline Licensure $_{t-29}$ & $\begin{array}{l}-0.047 * \\
(0.027)\end{array}$ & $\begin{array}{c}0.065^{* * *} \\
(0.024)\end{array}$ & $\begin{array}{c}0.068 * * * \\
(0.023)\end{array}$ & $\begin{array}{c}0.059 * * \\
(0.023)\end{array}$ & $\begin{array}{c}0.054^{* *} \\
(0.024)\end{array}$ & $\begin{array}{c}0.180 * * * \\
(0.034)\end{array}$ & $\begin{array}{c}-0.091^{* * *} \\
(0.023)\end{array}$ \\
\hline Licensure $_{t-30}$ & $\begin{array}{l}-0.059 * \\
(0.032)\end{array}$ & $\begin{array}{c}0.098^{* * *} \\
(0.025)\end{array}$ & $\begin{array}{c}0.102 * * * \\
(0.024)\end{array}$ & $\begin{array}{c}0.094^{* * * *} \\
(0.025)\end{array}$ & $\begin{array}{c}0.088 * * * \\
(0.025)\end{array}$ & $\begin{array}{c}0.147 * * * \\
(0.040)\end{array}$ & $\begin{array}{c}-0.092 * * * \\
(0.024)\end{array}$ \\
\hline Licensure $_{t-31 \mathrm{f}}$ & $\begin{array}{c}0.160 * * * \\
(0.017)\end{array}$ & $\begin{array}{c}0.123 * * * \\
(0.017)\end{array}$ & $\begin{array}{c}0.121 * * * \\
(0.017)\end{array}$ & $\begin{array}{c}0.120^{* * *} \\
(0.017)\end{array}$ & $\begin{array}{c}0.112^{* * *} \\
(0.017)\end{array}$ & $\begin{array}{c}0.395 * * * \\
(0.027)\end{array}$ & $\begin{array}{c}-0.071^{* * *} \\
(0.022)\end{array}$ \\
\hline Individual Covariates & YES & YES & YES & YES & YES & YES & YES \\
\hline OCC FE & NO & YES & YES & YES & YES & NO & YES \\
\hline 1-digit SOC 2000 & NO & NO & YES & NO & NO & NO & NO \\
\hline 2-digit SOC 2000 & NO & NO & NO & YES & NO & NO & NO \\
\hline 3-digit SOC 2000 & NO & NO & NO & NO & YES & NO & NO \\
\hline Year FE & YES & YES & YES & YES & YES & YES & YES \\
\hline State FE & YES & YES & YES & YES & YES & YES & YES \\
\hline $\mathrm{H}_{0}$ : doption $_{(\mathrm{t} 0 \sim \mathrm{t}+31 \mathrm{f})}=0$ & 0 & 0 & 0 & 0 & 0 & 0 & 0 \\
\hline $\mathrm{H}_{0}$ : adoption $_{(\mathrm{t}+1 \sim \mathrm{t}+6)}=0$ & 0 & 0.310 & 0.382 & 0.424 & 0.521 & 0.00787 & 0.149 \\
\hline R-squared & 0.347 & 0.366 & 0.411 & 0.423 & 0.449 & 0.347 & 0.455 \\
\hline Observations & $11,240,956$ & $11,240,956$ & $11,240,956$ & $11,240,956$ & $11,240,956$ & $1,997,042$ & $1,997,042$ \\
\hline
\end{tabular}

Note: All models include indicators for gender, race (white vs. others), dummies for marital status (married, married but absent, separated/divorced/widowed vs. unmarried), years of education, potential experience and a quadratic function in potential experience; *** significant at the 0.01 level; ${ }^{* *}$ significant at the 0.05 level; * significant at the 0.1 level; standard errors are constructed using the heteroscedasticity robust covariance matrix that allows for clustering at the state-occupation level. 
Panel B. Occupations that Changed Their Regulation Status over the Period of Our Analysis

\begin{tabular}{|c|c|c|c|c|c|c|c|}
\hline \multirow{2}{*}{ Control Group } & (1) & (2) & (3) & (4) & (5) & (6) & (7) \\
\hline & \multicolumn{5}{|c|}{$\begin{array}{l}\text { Relative to Individuals in Never Licensed Occupations Throughout } \\
\text { Our period of Analysis }\end{array}$} & \multicolumn{2}{|c|}{$\begin{array}{l}\text { Relative to Unlicensed } \\
\text { Workers in Universally } \\
\text { Licensed Occupations } \\
\text { Prior to States Passing } \\
\text { Licensing Statutes }\end{array}$} \\
\hline Leads and Lags: & & & & & & & \\
\hline Licensure $_{t+6}$ & $\begin{array}{c}-0.216^{* * * *} \\
(0.039)\end{array}$ & $\begin{array}{c}0.008 \\
(0.023)\end{array}$ & $\begin{array}{c}0.015 \\
(0.022)\end{array}$ & $\begin{array}{c}0.015 \\
(0.021)\end{array}$ & $\begin{array}{c}0.014 \\
(0.021)\end{array}$ & $\begin{array}{l}0.083^{*} \\
(0.043)\end{array}$ & $\begin{array}{c}0.005 \\
(0.020)\end{array}$ \\
\hline Licensure $_{t+5}$ & $\begin{array}{c}-0.205^{* * * *} \\
(0.024)\end{array}$ & $\begin{array}{l}0.049^{*} \\
(0.029)\end{array}$ & $\begin{array}{c}0.045 \\
(0.030)\end{array}$ & $\begin{array}{c}0.043 \\
(0.030)\end{array}$ & $\begin{array}{c}0.036 \\
(0.032)\end{array}$ & $\begin{array}{c}0.007 \\
(0.026)\end{array}$ & $\begin{array}{l}-0.012 \\
(0.020)\end{array}$ \\
\hline Licensure $_{t+4}$ & $\begin{array}{c}-0.194 * * * \\
(0.036)\end{array}$ & $\begin{array}{l}0.064^{*} \\
(0.039)\end{array}$ & $\begin{array}{c}0.063 \\
(0.041)\end{array}$ & $\begin{array}{c}0.062 \\
(0.041)\end{array}$ & $\begin{array}{c}0.061 \\
(0.043)\end{array}$ & $\begin{array}{c}0.016 \\
(0.034)\end{array}$ & $\begin{array}{l}-0.016 \\
(0.029)\end{array}$ \\
\hline Licensure $_{t+3}$ & $\begin{array}{c}-0.180 * * * \\
(0.027)\end{array}$ & $\begin{array}{c}0.012 \\
(0.041)\end{array}$ & $\begin{array}{c}0.012 \\
(0.043)\end{array}$ & $\begin{array}{c}0.011 \\
(0.043)\end{array}$ & $\begin{array}{c}0.014 \\
(0.044)\end{array}$ & $\begin{array}{l}0.069 * * \\
(0.031)\end{array}$ & $\begin{array}{l}-0.015 \\
(0.029)\end{array}$ \\
\hline Licensure $_{t+2}$ & $\begin{array}{c}-0.134^{* * *} \\
(0.031)\end{array}$ & $\begin{array}{c}0.072 \\
(0.044)\end{array}$ & $\begin{array}{c}0.063 \\
(0.045)\end{array}$ & $\begin{array}{c}0.060 \\
(0.046)\end{array}$ & $\begin{array}{c}0.051 \\
(0.048)\end{array}$ & $\begin{array}{c}0.024 \\
(0.034)\end{array}$ & $\begin{array}{l}-0.057 * \\
(0.033)\end{array}$ \\
\hline Licensure $_{t+1}$ & $\begin{array}{c}-0.145^{* * *} \\
(0.025)\end{array}$ & $\begin{array}{l}-0.016 \\
(0.063)\end{array}$ & $\begin{array}{l}-0.026 \\
(0.067)\end{array}$ & $\begin{array}{l}-0.029 \\
(0.067)\end{array}$ & $\begin{array}{l}-0.034 \\
(0.069)\end{array}$ & $\begin{array}{c}0.029 \\
(0.029)\end{array}$ & $\begin{array}{c}-0.109 * * \\
(0.050)\end{array}$ \\
\hline Licensure $_{t+0}$ & $\begin{array}{c}-0.207^{* * * *} \\
(0.034)\end{array}$ & $\begin{array}{l}0.060^{*} \\
(0.033)\end{array}$ & $\begin{array}{c}0.065^{* *} \\
(0.031)\end{array}$ & $\begin{array}{c}0.065^{* *} \\
(0.031)\end{array}$ & $\begin{array}{c}0.061^{* *} \\
(0.031)\end{array}$ & $\begin{array}{c}0.012 \\
(0.027)\end{array}$ & $\begin{array}{l}-0.018 \\
(0.019)\end{array}$ \\
\hline Licensure $_{t-1}$ & $\begin{array}{c}-0.152^{* * * *} \\
(0.029)\end{array}$ & $\begin{array}{l}0.039 * \\
(0.024)\end{array}$ & $\begin{array}{c}0.037 \\
(0.024)\end{array}$ & $\begin{array}{c}0.034 \\
(0.025)\end{array}$ & $\begin{array}{c}0.026 \\
(0.025)\end{array}$ & $\begin{array}{l}0.057 * * \\
(0.025)\end{array}$ & $\begin{array}{l}-0.032 \\
(0.020)\end{array}$ \\
\hline Licensure $_{t-2}$ & $\begin{array}{c}-0.220^{* * *} \\
(0.022)\end{array}$ & $\begin{array}{c}0.043 * * \\
(0.021)\end{array}$ & $\begin{array}{l}0.048^{* *} \\
(0.020)\end{array}$ & $\begin{array}{l}0.048 * * \\
(0.020)\end{array}$ & $\begin{array}{c}0.047 * * \\
(0.019)\end{array}$ & $\begin{array}{c}0.010 \\
(0.022)\end{array}$ & $\begin{array}{l}-0.021 \\
(0.017)\end{array}$ \\
\hline Licensure $_{t-3}$ & $\begin{array}{c}-0.212 * * * \\
(0.020)\end{array}$ & $\begin{array}{c}0.047 * * \\
(0.018)\end{array}$ & $\begin{array}{c}0.048 * * * \\
(0.018)\end{array}$ & $\begin{array}{c}0.046^{* *} \\
(0.018)\end{array}$ & $\begin{array}{c}0.041^{* *} \\
(0.018)\end{array}$ & $\begin{array}{l}-0.011 \\
(0.018)\end{array}$ & $\begin{array}{c}-0.050 * * * \\
(0.015)\end{array}$ \\
\hline Licensure $_{t-4}$ & $\begin{array}{c}-0.191 * * * \\
(0.022)\end{array}$ & $\begin{array}{c}0.084 * * * \\
(0.020)\end{array}$ & $\begin{array}{c}0.086^{* * *} \\
(0.020)\end{array}$ & $\begin{array}{c}0.084 * * * \\
(0.020)\end{array}$ & $\begin{array}{c}0.080 * * * \\
(0.020)\end{array}$ & $\begin{array}{c}0.017 \\
(0.023)\end{array}$ & $\begin{array}{c}-0.014 \\
(0.017)\end{array}$ \\
\hline Licensure $_{t-5}$ & $\begin{array}{c}-0.190^{* * * *} \\
(0.020)\end{array}$ & $\begin{array}{c}0.074 * * * \\
(0.018)\end{array}$ & $\begin{array}{c}0.074 * * * \\
(0.018)\end{array}$ & $\begin{array}{c}0.070 * * * \\
(0.019)\end{array}$ & $\begin{array}{c}0.065 * * * \\
(0.019)\end{array}$ & $\begin{array}{c}0.006 \\
(0.022)\end{array}$ & $\begin{array}{c}-0.033^{* *} \\
(0.017)\end{array}$ \\
\hline Licensure $_{t-6}$ & $\begin{array}{c}-0.182 * * * \\
(0.020)\end{array}$ & $\begin{array}{c}0.092 * * * \\
(0.018)\end{array}$ & $\begin{array}{c}0.090 * * * \\
(0.019)\end{array}$ & $\begin{array}{c}0.087 * * * \\
(0.019)\end{array}$ & $\begin{array}{c}0.081^{* * *} \\
(0.020)\end{array}$ & $\begin{array}{c}0.012 \\
(0.023)\end{array}$ & $\begin{array}{l}-0.024 \\
(0.016)\end{array}$ \\
\hline Licensure $_{t-7}$ & $\begin{array}{c}-0.176^{* * *} \\
(0.018)\end{array}$ & $\begin{array}{c}0.068 * * * \\
(0.016)\end{array}$ & $\begin{array}{c}0.065^{* * *} * \\
(0.017)\end{array}$ & $\begin{array}{c}0.063^{* * *} \\
(0.017)\end{array}$ & $\begin{array}{c}0.056 * * * \\
(0.018)\end{array}$ & $\begin{array}{c}0.027 \\
(0.019)\end{array}$ & $\begin{array}{c}-0.031^{* *} \\
(0.014)\end{array}$ \\
\hline Licensure $_{t-8}$ & $\begin{array}{c}-0.193^{* * *} \\
(0.020)\end{array}$ & $\begin{array}{c}0.072 * * * \\
(0.017)\end{array}$ & $\begin{array}{c}0.070 * * * \\
(0.017)\end{array}$ & $\begin{array}{c}0.068 * * * \\
(0.017)\end{array}$ & $\begin{array}{c}0.060 * * * \\
(0.017)\end{array}$ & $\begin{array}{l}-0.008 \\
(0.020)\end{array}$ & $\begin{array}{c}-0.053^{* * *} \\
(0.013)\end{array}$ \\
\hline Licensure $_{t-9}$ & $\begin{array}{c}-0.189 * * * \\
(0.020)\end{array}$ & $\begin{array}{c}0.045^{* *} \\
(0.018)\end{array}$ & $\begin{array}{c}0.041^{* *} \\
(0.018)\end{array}$ & $\begin{array}{c}0.039 * * \\
(0.018)\end{array}$ & $\begin{array}{l}0.031 * \\
(0.019)\end{array}$ & $\begin{array}{l}-0.002 \\
(0.019)\end{array}$ & $\begin{array}{c}-0.073 * * * \\
(0.016)\end{array}$ \\
\hline Licensure $_{t-10}$ & $\begin{array}{c}-0.191^{* * * *} \\
(0.018)\end{array}$ & $\begin{array}{c}0.087 * * * \\
(0.016)\end{array}$ & $\begin{array}{c}0.084 * * * \\
(0.016)\end{array}$ & $\begin{array}{c}0.082 * * * \\
(0.017)\end{array}$ & $\begin{array}{c}0.072 * * * \\
(0.017)\end{array}$ & $\begin{array}{l}-0.007 \\
(0.021)\end{array}$ & $\begin{array}{c}-0.051 * * * \\
(0.014)\end{array}$ \\
\hline Licensure $_{t-11}$ & $\begin{array}{c}-0.167^{* * *} \\
(0.021)\end{array}$ & $\begin{array}{c}0.060^{* * *} \\
(0.016)\end{array}$ & $\begin{array}{c}0.055^{* * *} \\
(0.016)\end{array}$ & $\begin{array}{c}0.052^{* * *} \\
(0.016)\end{array}$ & $\begin{array}{c}0.044 * * * \\
(0.017)\end{array}$ & $\begin{array}{c}0.023 \\
(0.019)\end{array}$ & $\begin{array}{c}-0.060 * * * \\
(0.014)\end{array}$ \\
\hline Licensure $_{t-12}$ & $\begin{array}{c}-0.192 * * * \\
(0.019)\end{array}$ & $\begin{array}{c}0.077 * * * \\
(0.017)\end{array}$ & $\begin{array}{c}0.075^{* * *} * \\
(0.017)\end{array}$ & $\begin{array}{c}0.073^{* * *} \\
(0.017)\end{array}$ & $\begin{array}{c}0.062 * * * \\
(0.017)\end{array}$ & $\begin{array}{l}-0.001 \\
(0.023)\end{array}$ & $\begin{array}{c}-0.054 * * * \\
(0.015)\end{array}$ \\
\hline Licensure $_{t-13}$ & $\begin{array}{c}-0.191^{* * *} \\
(0.017)\end{array}$ & $\begin{array}{c}0.065 * * * \\
(0.020)\end{array}$ & $\begin{array}{c}0.064^{* * *} \\
(0.019)\end{array}$ & $\begin{array}{c}0.061^{* * *} \\
(0.020)\end{array}$ & $\begin{array}{c}0.051^{* *} \\
(0.020)\end{array}$ & $\begin{array}{c}0.005 \\
(0.022)\end{array}$ & $\begin{array}{c}-0.063 * * * \\
(0.017)\end{array}$ \\
\hline Licensure $_{t-14}$ & $\begin{array}{c}-0.204^{* * *} \\
(0.018)\end{array}$ & $\begin{array}{c}0.074 * * * \\
(0.018)\end{array}$ & $\begin{array}{c}0.074 * * * \\
(0.018)\end{array}$ & $\begin{array}{c}0.071^{* * *} \\
(0.019)\end{array}$ & $\begin{array}{c}0.062 * * * \\
(0.019)\end{array}$ & $\begin{array}{c}0.008 \\
(0.024)\end{array}$ & $\begin{array}{c}-0.045^{* * *} \\
(0.017)\end{array}$ \\
\hline Licensure $_{t-15}$ & $\begin{array}{c}-0.209 * * * \\
(0.017)\end{array}$ & $\begin{array}{c}0.054 * * * \\
(0.017)\end{array}$ & $\begin{array}{c}0.053^{* * *} \\
(0.017)\end{array}$ & $\begin{array}{c}0.051^{* * *} \\
(0.017)\end{array}$ & $\begin{array}{c}0.040 * * \\
(0.018)\end{array}$ & $\begin{array}{c}0.004 \\
(0.022)\end{array}$ & $\begin{array}{c}-0.062 * * * \\
(0.016)\end{array}$ \\
\hline Licensure $_{t-16}$ & $\begin{array}{c}-0.209 * * * \\
(0.018)\end{array}$ & $\begin{array}{c}0.059 * * * \\
(0.018)\end{array}$ & $\begin{array}{c}0.055^{* * *} \\
(0.018)\end{array}$ & $\begin{array}{c}0.052^{* * *} \\
(0.018)\end{array}$ & $\begin{array}{c}0.041^{* *} \\
(0.019)\end{array}$ & $\begin{array}{l}-0.002 \\
(0.023)\end{array}$ & $\begin{array}{c}-0.067 * * * \\
(0.017)\end{array}$ \\
\hline
\end{tabular}




\begin{tabular}{|c|c|c|c|c|c|c|c|}
\hline Licensure $_{t-17}$ & $\begin{array}{c}-0.187 * * * \\
(0.021)\end{array}$ & $\begin{array}{c}0.047 * * * \\
(0.016)\end{array}$ & $\begin{array}{c}0.043^{* * *} \\
(0.016)\end{array}$ & $\begin{array}{c}0.040 * * \\
(0.017)\end{array}$ & $\begin{array}{l}0.031^{*} \\
(0.017)\end{array}$ & $\begin{array}{l}0.036^{*} \\
(0.020)\end{array}$ & $\begin{array}{c}-0.057 * * * \\
(0.015)\end{array}$ \\
\hline Licensure $_{t-18}$ & $\begin{array}{c}-0.199 * * * \\
(0.024)\end{array}$ & $\begin{array}{c}0.050 * * \\
(0.020)\end{array}$ & $\begin{array}{c}0.044^{* *} \\
(0.019)\end{array}$ & $\begin{array}{c}0.041^{* *} \\
(0.020)\end{array}$ & $\begin{array}{c}0.029 \\
(0.020)\end{array}$ & $\begin{array}{c}0.008 \\
(0.026)\end{array}$ & $\begin{array}{c}-0.073^{* * *} \\
(0.019)\end{array}$ \\
\hline Licensure $_{t-19}$ & $\begin{array}{c}-0.143^{* * *} \\
(0.040)\end{array}$ & $\begin{array}{c}0.010 \\
(0.027)\end{array}$ & $\begin{array}{c}0.004 \\
(0.027)\end{array}$ & $\begin{array}{l}-0.002 \\
(0.027)\end{array}$ & $\begin{array}{l}-0.013 \\
(0.027)\end{array}$ & $\begin{array}{l}0.061^{*} \\
(0.036)\end{array}$ & $\begin{array}{c}-0.096 * * * \\
(0.026)\end{array}$ \\
\hline Licensure $_{t-20}$ & $\begin{array}{c}-0.200^{* * *} \\
(0.021)\end{array}$ & $\begin{array}{c}0.062 * * * \\
(0.023)\end{array}$ & $\begin{array}{c}0.054^{* *} \\
(0.022)\end{array}$ & $\begin{array}{c}0.050 * * \\
(0.023)\end{array}$ & $\begin{array}{c}0.037 \\
(0.023)\end{array}$ & $\begin{array}{c}0.026 \\
(0.029)\end{array}$ & $\begin{array}{c}-0.061 * * * \\
(0.020)\end{array}$ \\
\hline Licensure $_{t-21}$ & $\begin{array}{c}-0.075^{* *} \\
(0.035)\end{array}$ & $\begin{array}{c}0.071 * * * \\
(0.019)\end{array}$ & $\begin{array}{c}0.070 * * * \\
(0.019)\end{array}$ & $\begin{array}{c}0.066 * * * \\
(0.019)\end{array}$ & $\begin{array}{c}0.057 * * * \\
(0.019)\end{array}$ & $\begin{array}{c}0.140 * * * \\
(0.031)\end{array}$ & $\begin{array}{l}-0.035^{*} \\
(0.020)\end{array}$ \\
\hline Licensure $_{t-22}$ & $\begin{array}{c}-0.159 * * * \\
(0.019)\end{array}$ & $\begin{array}{c}0.080 * * * \\
(0.021)\end{array}$ & $\begin{array}{c}0.078 * * * \\
(0.021)\end{array}$ & $\begin{array}{c}0.074 * * * \\
(0.021)\end{array}$ & $\begin{array}{c}0.067 * * * \\
(0.021)\end{array}$ & $\begin{array}{c}0.074 * * \\
(0.032)\end{array}$ & $\begin{array}{c}-0.039^{*} \\
(0.021)\end{array}$ \\
\hline Licensure $_{t-23}$ & $\begin{array}{c}-0.119 * * * \\
(0.020)\end{array}$ & $\begin{array}{c}0.083 * * * \\
(0.022)\end{array}$ & $\begin{array}{c}0.092 * * * \\
(0.021)\end{array}$ & $\begin{array}{c}0.079 * * * \\
(0.022)\end{array}$ & $\begin{array}{c}0.077 * * * \\
(0.022)\end{array}$ & $\begin{array}{c}0.110 * * * \\
(0.031)\end{array}$ & $\begin{array}{l}-0.026 \\
(0.022)\end{array}$ \\
\hline Licensure $_{t-24}$ & $\begin{array}{c}-0.153^{* * *} \\
(0.018)\end{array}$ & $\begin{array}{c}0.106 * * * \\
(0.021)\end{array}$ & $\begin{array}{c}0.100 * * * \\
(0.020)\end{array}$ & $\begin{array}{c}0.098 * * * \\
(0.021)\end{array}$ & $\begin{array}{c}0.088 * * * \\
(0.021)\end{array}$ & $\begin{array}{c}0.086 * * \\
(0.034)\end{array}$ & $\begin{array}{l}-0.019 \\
(0.022)\end{array}$ \\
\hline Licensure $_{t-25}$ & $\begin{array}{c}-0.125^{* * *} \\
(0.019)\end{array}$ & $\begin{array}{c}0.098 * * * \\
(0.021)\end{array}$ & $\begin{array}{c}0.101^{* * *} \\
(0.020)\end{array}$ & $\begin{array}{c}0.092 * * * \\
(0.021)\end{array}$ & $\begin{array}{c}0.086 * * * \\
(0.021)\end{array}$ & $\begin{array}{c}0.108^{* * *} \\
(0.031)\end{array}$ & $\begin{array}{c}-0.021 \\
(0.020)\end{array}$ \\
\hline Licensure $_{t-26}$ & $\begin{array}{c}-0.154^{* * *} \\
(0.019)\end{array}$ & $\begin{array}{c}0.087 * * * \\
(0.022)\end{array}$ & $\begin{array}{c}0.081^{* * *} \\
(0.021)\end{array}$ & $\begin{array}{c}0.078 * * * \\
(0.021)\end{array}$ & $\begin{array}{c}0.067 * * * \\
(0.021)\end{array}$ & $\begin{array}{c}0.080^{* *} \\
(0.032)\end{array}$ & $\begin{array}{c}-0.044^{* *} \\
(0.021)\end{array}$ \\
\hline Licensure $_{t-27}$ & $\begin{array}{c}-0.121^{* * *} \\
(0.021)\end{array}$ & $\begin{array}{c}0.075^{* * *} \\
(0.021)\end{array}$ & $\begin{array}{c}0.072 * * * \\
(0.020)\end{array}$ & $\begin{array}{c}0.069 * * * \\
(0.020)\end{array}$ & $\begin{array}{c}0.061 * * * \\
(0.020)\end{array}$ & $\begin{array}{c}0.126 * * * \\
(0.029)\end{array}$ & $\begin{array}{l}-0.031 \\
(0.019)\end{array}$ \\
\hline Licensure $_{t-28}$ & $\begin{array}{c}-0.111^{* * *} \\
(0.025)\end{array}$ & $\begin{array}{c}0.090 * * * \\
(0.022)\end{array}$ & $\begin{array}{c}0.089 * * * \\
(0.021)\end{array}$ & $\begin{array}{c}0.086 * * * \\
(0.021)\end{array}$ & $\begin{array}{c}0.077 * * * \\
(0.021)\end{array}$ & $\begin{array}{c}0.119 * * * \\
(0.034)\end{array}$ & $\begin{array}{l}-0.039^{*} \\
(0.022)\end{array}$ \\
\hline Licensure $_{t-29}$ & $\begin{array}{l}-0.042 \\
(0.027)\end{array}$ & $\begin{array}{c}0.075 * * * \\
(0.024)\end{array}$ & $\begin{array}{c}0.079 * * * \\
(0.023)\end{array}$ & $\begin{array}{c}0.070 * * * \\
(0.024)\end{array}$ & $\begin{array}{c}0.064 * * * \\
(0.024)\end{array}$ & $\begin{array}{c}0.173^{* * *} \\
(0.036)\end{array}$ & $\begin{array}{l}-0.040 \\
(0.025)\end{array}$ \\
\hline Licensure $_{t-30}$ & $\begin{array}{l}-0.051 \\
(0.032)\end{array}$ & $\begin{array}{c}0.108 * * * \\
(0.025)\end{array}$ & $\begin{array}{c}0.112^{* * *} \\
(0.024)\end{array}$ & $\begin{array}{c}0.104 * * * \\
(0.025)\end{array}$ & $\begin{array}{c}0.098 * * * \\
(0.025)\end{array}$ & $\begin{array}{c}0.161^{* * *} \\
(0.041)\end{array}$ & $\begin{array}{l}-0.031 \\
(0.023)\end{array}$ \\
\hline Licensure $_{t-31 \mathrm{f}}$ & $\begin{array}{c}0.100 * * * \\
(0.020)\end{array}$ & $\begin{array}{c}0.134 * * * \\
(0.017)\end{array}$ & $\begin{array}{c}0.132 * * * \\
(0.017)\end{array}$ & $\begin{array}{c}0.131^{* * *} \\
(0.017)\end{array}$ & $\begin{array}{c}0.122 * * * \\
(0.017)\end{array}$ & $\begin{array}{c}0.338 * * * \\
(0.026)\end{array}$ & $\begin{array}{l}-0.003 \\
(0.020)\end{array}$ \\
\hline Individual Covariates & YES & YES & YES & YES & YES & YES & YES \\
\hline OCC FE & NO & YES & YES & YES & YES & NO & YES \\
\hline 1-digit SOC 2000 & NO & NO & YES & NO & NO & NO & NO \\
\hline 2-digit SOC 2000 & NO & NO & NO & YES & NO & NO & NO \\
\hline 3-digit SOC 2000 & NO & NO & NO & NO & YES & NO & NO \\
\hline Year FE & YES & YES & YES & YES & YES & YES & YES \\
\hline State FE & YES & YES & YES & YES & YES & YES & YES \\
\hline $\mathrm{H}_{0}$ : $\operatorname{adoption}_{(\mathrm{t} 0 \sim \mathrm{t}+31 \mathrm{f})}=0$ & 0 & 0 & 0 & 0 & 0 & 0 & 0 \\
\hline $\mathrm{H}_{0}$ : adoption $_{(\mathrm{t}+1 \sim \mathrm{t}+6)}=0$ & 0 & 0.271 & 0.338 & 0.380 & 0.484 & 0.122 & 0.341 \\
\hline R-squared & 0.316 & 0.327 & 0.378 & 0.392 & 0.421 & 0.265 & 0.349 \\
\hline Observations & $10,829,059$ & $10,829,059$ & $10,829,059$ & $10,829,059$ & $10,829,059$ & $1,585,145$ & $1,585,145$ \\
\hline
\end{tabular}

Note: All models include indicators for gender, race (white vs. others), dummies for marital status (married, married but absent, separated/divorced/widowed vs. unmarried), years of education, potential experience and a quadratic function in potential experience; ${ }^{* * *}$ significant at the 0.01 level; ${ }^{* *}$ significant at the 0.05 level; * significant at the 0.1 level; standard errors are constructed using the heteroscedasticity robust covariance matrix that allows for clustering at the state-occupation level. 
Appendix 7. The Estimated Impact of Occupational Licensing on Annual Hours Worked

Panel A. 13 Universally Licensed Occupations

\begin{tabular}{|c|c|c|c|c|c|c|c|}
\hline \multirow{2}{*}{ Control Group: } & (1) & (2) & (3) & (4) & (5) & \multirow{2}{*}{\multicolumn{2}{|c|}{$\begin{array}{c}(6) \\
\text { Relative to Unlicensed } \\
\text { Workers in Universally } \\
\text { Licensed Occupations } \\
\text { Prior to States Passing } \\
\text { Licensing Statutes } \\
\end{array}$}} \\
\hline & \multicolumn{5}{|c|}{$\begin{array}{c}\text { Relative to Individuals in Never Licensed Occupations Throughout } \\
\text { Our period of Analysis }\end{array}$} & & \\
\hline Leads and Lags: & & & & & & & \\
\hline Licensure $_{t+6}$ & $\begin{array}{c}-78.539 * * * \\
(28.185)\end{array}$ & $\begin{array}{l}-14.814 \\
(29.103)\end{array}$ & $\begin{array}{l}-12.870 \\
(28.876)\end{array}$ & $\begin{array}{l}-12.604 \\
(28.985)\end{array}$ & $\begin{array}{l}-13.291 \\
(29.095)\end{array}$ & $\begin{array}{l}-24.598 \\
(29.767)\end{array}$ & $\begin{array}{l}-21.296 \\
(23.831)\end{array}$ \\
\hline Licensure $_{t+5}$ & $\begin{array}{c}-88.132 * * * \\
(22.293)\end{array}$ & $\begin{array}{l}-36.101^{*} \\
(19.184)\end{array}$ & $\begin{array}{c}-37.220^{* *} \\
(18.441)\end{array}$ & $\begin{array}{l}-33.975^{*} \\
(18.361)\end{array}$ & $\begin{array}{l}-29.096 \\
(17.746)\end{array}$ & $\begin{array}{l}-14.732 \\
(20.932)\end{array}$ & $\begin{array}{c}-40.373^{* * *} \\
(14.703)\end{array}$ \\
\hline Licensure $_{t+4}$ & $\begin{array}{c}-116.651^{* * * *} \\
(34.658)\end{array}$ & $\begin{array}{c}-64.410 * * \\
(31.860)\end{array}$ & $\begin{array}{c}-64.557^{* *} \\
(30.998)\end{array}$ & $\begin{array}{c}-63.536^{* *} \\
(31.489)\end{array}$ & $\begin{array}{l}-57.868^{*} \\
(30.354)\end{array}$ & $\begin{array}{l}-41.037 \\
(33.963)\end{array}$ & $\begin{array}{c}-68.416^{* *} \\
(26.538)\end{array}$ \\
\hline Licensure $_{t+3}$ & $\begin{array}{c}-89.828 * * * \\
(26.993)\end{array}$ & $\begin{array}{l}-31.998 \\
(24.590)\end{array}$ & $\begin{array}{l}-31.843 \\
(23.932)\end{array}$ & $\begin{array}{l}-30.776 \\
(23.622)\end{array}$ & $\begin{array}{l}-29.222 \\
(22.067)\end{array}$ & $\begin{array}{l}-16.989 \\
(28.147)\end{array}$ & $\begin{array}{l}-39.267 * \\
(22.890)\end{array}$ \\
\hline Licensure $_{t+2}$ & $\begin{array}{c}-100.886 * * * \\
(28.067)\end{array}$ & $\begin{array}{l}-42.312 \\
(27.837)\end{array}$ & $\begin{array}{l}-44.502 \\
(27.125)\end{array}$ & $\begin{array}{l}-42.134 \\
(28.178)\end{array}$ & $\begin{array}{l}-38.677 \\
(26.132)\end{array}$ & $\begin{array}{l}-15.118 \\
(31.876)\end{array}$ & $\begin{array}{c}-54.519 * * \\
(24.220)\end{array}$ \\
\hline Licensure $_{t+1}$ & $\begin{array}{c}-84.449 * * * \\
(24.814)\end{array}$ & $\begin{array}{l}-17.284 \\
(25.231)\end{array}$ & $\begin{array}{l}-19.533 \\
(24.284)\end{array}$ & $\begin{array}{l}-18.462 \\
(24.117)\end{array}$ & $\begin{array}{l}-17.952 \\
(22.385)\end{array}$ & $\begin{array}{c}0.583 \\
(27.520)\end{array}$ & $\begin{array}{l}-27.738 \\
(24.690)\end{array}$ \\
\hline Licensure $_{t+0}$ & $\begin{array}{c}-75.601^{* * *} \\
(20.644)\end{array}$ & $\begin{array}{l}-24.085 \\
(18.067)\end{array}$ & $\begin{array}{l}-22.607 \\
(18.503)\end{array}$ & $\begin{array}{l}-21.566 \\
(17.880)\end{array}$ & $\begin{array}{l}-15.749 \\
(17.588)\end{array}$ & $\begin{array}{c}-4.112 \\
(22.456)\end{array}$ & $\begin{array}{l}-31.637^{*} \\
(16.636)\end{array}$ \\
\hline Licensure $_{t-1}$ & $\begin{array}{c}-57.801^{* * * *} \\
(19.143)\end{array}$ & $\begin{array}{c}1.099 \\
(15.781)\end{array}$ & $\begin{array}{c}0.485 \\
(15.744)\end{array}$ & $\begin{array}{c}0.514 \\
(15.485)\end{array}$ & $\begin{array}{c}2.879 \\
(15.359)\end{array}$ & $\begin{array}{c}23.813 \\
(18.144)\end{array}$ & $\begin{array}{c}-7.342 \\
(15.523)\end{array}$ \\
\hline Licensure $_{t-2}$ & $\begin{array}{c}-56.157 * * * \\
(13.874)\end{array}$ & $\begin{array}{c}-4.314 \\
(13.223)\end{array}$ & $\begin{array}{c}-2.718 \\
(13.461)\end{array}$ & $\begin{array}{c}-1.684 \\
(13.107)\end{array}$ & $\begin{array}{c}4.492 \\
(13.016)\end{array}$ & $\begin{array}{c}12.078 \\
(16.285)\end{array}$ & $\begin{array}{l}-10.960 \\
(12.655)\end{array}$ \\
\hline Licensure $_{t-3}$ & $\begin{array}{c}-51.816^{* * * *} \\
(15.026)\end{array}$ & $\begin{array}{l}-1.265 \\
(13.542)\end{array}$ & $\begin{array}{c}-0.795 \\
(13.694)\end{array}$ & $\begin{array}{c}1.589 \\
(13.374)\end{array}$ & $\begin{array}{c}7.769 \\
(13.308)\end{array}$ & $\begin{array}{c}14.414 \\
(13.212)\end{array}$ & $\begin{array}{l}-18.237 \\
(13.199)\end{array}$ \\
\hline Licensure $_{t-4}$ & $\begin{array}{c}-36.065^{* *} \\
(18.243)\end{array}$ & $\begin{array}{c}12.854 \\
(16.939)\end{array}$ & $\begin{array}{c}13.760 \\
(16.853)\end{array}$ & $\begin{array}{c}15.517 \\
(16.370)\end{array}$ & $\begin{array}{c}21.842 \\
(16.214)\end{array}$ & $\begin{array}{c}23.300 \\
(16.548)\end{array}$ & $\begin{array}{l}-10.223 \\
(15.252)\end{array}$ \\
\hline Licensure $_{t-5}$ & $\begin{array}{l}-26.959 \\
(17.317)\end{array}$ & $\begin{array}{c}21.712 \\
(15.682)\end{array}$ & $\begin{array}{c}21.820 \\
(15.739)\end{array}$ & $\begin{array}{c}23.694 \\
(15.602)\end{array}$ & $\begin{array}{l}29.997^{*} \\
(15.696)\end{array}$ & $\begin{array}{c}37.140 * * * \\
(14.309)\end{array}$ & $\begin{array}{c}-0.660 \\
(14.810)\end{array}$ \\
\hline Licensure $_{t-6}$ & $\begin{array}{l}-24.455 \\
(15.332)\end{array}$ & $\begin{array}{l}23.479 * \\
(13.393)\end{array}$ & $\begin{array}{l}23.378^{*} \\
(13.431)\end{array}$ & $\begin{array}{c}26.162^{* *} \\
(13.116)\end{array}$ & $\begin{array}{c}32.963 * * \\
(13.099)\end{array}$ & $\begin{array}{c}40.570 * * * \\
(12.274)\end{array}$ & $\begin{array}{c}2.729 \\
(11.963)\end{array}$ \\
\hline Licensure $_{t-7}$ & $\begin{array}{c}-31.157^{* * * *} \\
(11.154)\end{array}$ & $\begin{array}{c}18.950 \\
(11.546)\end{array}$ & $\begin{array}{c}18.376 \\
(11.614)\end{array}$ & $\begin{array}{l}20.584^{*} \\
(11.337)\end{array}$ & $\begin{array}{c}25.519 * * \\
(11.367)\end{array}$ & $\begin{array}{c}34.787 * * * \\
(11.943)\end{array}$ & $\begin{array}{c}-3.681 \\
(11.104)\end{array}$ \\
\hline Licensure $_{t-8}$ & $\begin{array}{c}-27.375^{* *} \\
(13.916)\end{array}$ & $\begin{array}{c}20.717 \\
(13.848)\end{array}$ & $\begin{array}{c}20.562 \\
(13.865)\end{array}$ & $\begin{array}{l}23.050^{*} \\
(13.465)\end{array}$ & $\begin{array}{c}29.639 * * \\
(13.358)\end{array}$ & $\begin{array}{c}38.741 * * * \\
(13.886)\end{array}$ & $\begin{array}{c}-1.226 \\
(13.666)\end{array}$ \\
\hline Licensure $_{t-9}$ & $\begin{array}{c}-17.726 \\
(11.907)\end{array}$ & $\begin{array}{c}33.877 * * * \\
(11.385)\end{array}$ & $\begin{array}{c}33.323 * * * \\
(11.468)\end{array}$ & $\begin{array}{c}35.360 * * * \\
(11.358)\end{array}$ & $\begin{array}{c}40.340 * * * \\
(11.394)\end{array}$ & $\begin{array}{c}51.066 * * * \\
(12.647)\end{array}$ & $\begin{array}{c}10.266 \\
(12.117)\end{array}$ \\
\hline Licensure $_{t-10}$ & $\begin{array}{c}1.779 \\
(16.760)\end{array}$ & $\begin{array}{c}47.775 * * * \\
(16.432)\end{array}$ & $\begin{array}{c}47.597 * * * \\
(16.356)\end{array}$ & $\begin{array}{c}50.089 * * * \\
(16.045)\end{array}$ & $\begin{array}{c}55.974 * * * \\
(15.831)\end{array}$ & $\begin{array}{c}65.943 * * * \\
(15.392)\end{array}$ & $\begin{array}{c}21.961 \\
(15.442)\end{array}$ \\
\hline Licensure $_{t-11}$ & $\begin{array}{c}-8.859 \\
(16.192)\end{array}$ & $\begin{array}{c}43.150 * * * \\
(16.573)\end{array}$ & $\begin{array}{c}42.486 * * * \\
(16.454)\end{array}$ & $\begin{array}{c}43.632 * * * \\
(16.362)\end{array}$ & $\begin{array}{c}48.736 * * * \\
(16.295)\end{array}$ & $\begin{array}{c}57.300 * * * \\
(17.194)\end{array}$ & $\begin{array}{c}16.244 \\
(16.417)\end{array}$ \\
\hline Licensure $_{t-12}$ & $\begin{array}{c}2.495 \\
(16.501)\end{array}$ & $\begin{array}{c}49.234 * * * \\
(17.419)\end{array}$ & $\begin{array}{c}49.098^{* * *} \\
(17.525)\end{array}$ & $\begin{array}{c}51.956^{* * *} \\
(17.245)\end{array}$ & $\begin{array}{c}57.576 * * * \\
(16.899)\end{array}$ & $\begin{array}{c}66.418 * * * \\
(15.371)\end{array}$ & $\begin{array}{c}21.245 \\
(14.586)\end{array}$ \\
\hline Licensure $_{t-13}$ & $\begin{array}{c}10.928 \\
(13.993)\end{array}$ & $\begin{array}{c}59.383 * * * \\
(15.955)\end{array}$ & $\begin{array}{c}59.473 * * * \\
(15.928)\end{array}$ & $\begin{array}{c}61.639 * * * \\
(15.565)\end{array}$ & $\begin{array}{c}67.411 * * * \\
(15.271)\end{array}$ & $\begin{array}{c}72.245^{* * *} \\
(15.822)\end{array}$ & $\begin{array}{c}29.416 * * \\
(14.195)\end{array}$ \\
\hline Licensure $_{t-14}$ & $\begin{array}{c}11.111 \\
(16.189)\end{array}$ & $\begin{array}{c}56.295^{* * *} \\
(18.410)\end{array}$ & $\begin{array}{c}56.516 * * * \\
(18.315)\end{array}$ & $\begin{array}{c}58.610^{* * *} \\
(17.900)\end{array}$ & $\begin{array}{c}64.830 * * * \\
(17.487)\end{array}$ & $\begin{array}{c}70.003^{* * *} \\
(17.718)\end{array}$ & $\begin{array}{c}25.286 \\
(16.242)\end{array}$ \\
\hline Licensure $_{t-15}$ & $\begin{array}{c}25.927 \\
(17.076)\end{array}$ & $\begin{array}{c}\text { 73.009*** } \\
(18.879)\end{array}$ & $\begin{array}{c}\text { 73.113*** } \\
(18.951)\end{array}$ & $\begin{array}{c}\text { 75.292*** } \\
(18.599)\end{array}$ & $\begin{array}{c}81.244^{* * *} \\
(18.270)\end{array}$ & $\begin{array}{c}85.344 * * * \\
(18.683)\end{array}$ & $\begin{array}{c}40.755^{* *} \\
(17.352)\end{array}$ \\
\hline
\end{tabular}




\begin{tabular}{|c|c|c|c|c|c|c|c|}
\hline Licensure $_{t-16}$ & $\begin{array}{c}32.487 \\
(19.773)\end{array}$ & $\begin{array}{c}79.122 * * * \\
(21.407)\end{array}$ & $\begin{array}{c}78.629 * * * \\
(21.599)\end{array}$ & $\begin{array}{c}81.443 * * * \\
(20.823)\end{array}$ & $\begin{array}{c}87.559 * * * \\
(20.501)\end{array}$ & $\begin{array}{c}91.631 * * * \\
(20.393)\end{array}$ & $\begin{array}{c}46.110^{* *} \\
(18.451)\end{array}$ \\
\hline Licensure $_{t-17}$ & $\begin{array}{c}14.249 \\
(22.067)\end{array}$ & $\begin{array}{c}64.138 * * * \\
(22.771)\end{array}$ & $\begin{array}{c}63.563 * * * \\
(22.963)\end{array}$ & $\begin{array}{c}65.846 * * * \\
(22.745)\end{array}$ & $\begin{array}{c}\text { 70.946*** } \\
(22.683)\end{array}$ & $\begin{array}{c}\text { 78.153*** } \\
(22.160)\end{array}$ & $\begin{array}{l}33.880 * \\
(20.451)\end{array}$ \\
\hline Licensure $_{t-18}$ & $\begin{array}{c}31.566 \\
(23.222)\end{array}$ & $\begin{array}{c}80.707 * * * \\
(23.950)\end{array}$ & $\begin{array}{c}79.558 * * * \\
(24.473)\end{array}$ & $\begin{array}{c}82.723 * * * \\
(23.651)\end{array}$ & $\begin{array}{c}88.718^{* * *} \\
(23.359)\end{array}$ & $\begin{array}{c}91.393 * * * \\
(24.185)\end{array}$ & $\begin{array}{c}44.833^{* *} \\
(21.269)\end{array}$ \\
\hline Licensure $_{t-19}$ & $\begin{array}{c}-9.409 \\
(12.723)\end{array}$ & $\begin{array}{c}51.810^{* * *} \\
(14.961)\end{array}$ & $\begin{array}{c}50.474 * * * \\
(15.155)\end{array}$ & $\begin{array}{c}53.189 * * * \\
(15.038)\end{array}$ & $\begin{array}{c}56.888 * * * \\
(15.269)\end{array}$ & $\begin{array}{c}65.682 * * * \\
(19.309)\end{array}$ & $\begin{array}{l}27.976^{*} \\
(15.249)\end{array}$ \\
\hline Licensure $_{t-20}$ & $\begin{array}{c}-4.501 \\
(14.736)\end{array}$ & $\begin{array}{c}45.207 * * \\
(17.743)\end{array}$ & $\begin{array}{c}43.519 * * \\
(18.111)\end{array}$ & $\begin{array}{c}47.269 * * * \\
(17.285)\end{array}$ & $\begin{array}{c}53.284 * * * \\
(17.167)\end{array}$ & $\begin{array}{c}60.855^{* * *} \\
(23.124)\end{array}$ & $\begin{array}{c}19.660 \\
(17.556)\end{array}$ \\
\hline Licensure $_{t-21}$ & $\begin{array}{c}-52.190 * * * \\
(14.554)\end{array}$ & $\begin{array}{c}10.066 \\
(17.227)\end{array}$ & $\begin{array}{c}10.124 \\
(17.044)\end{array}$ & $\begin{array}{c}12.241 \\
(17.030)\end{array}$ & $\begin{array}{c}17.007 \\
(17.243)\end{array}$ & $\begin{array}{c}22.747 \\
(21.853)\end{array}$ & $\begin{array}{c}-10.013 \\
(18.780)\end{array}$ \\
\hline Licensure $_{t-22}$ & $\begin{array}{c}-27.545^{* *} \\
(12.521)\end{array}$ & $\begin{array}{c}23.718 \\
(15.551)\end{array}$ & $\begin{array}{c}23.544 \\
(15.734)\end{array}$ & $\begin{array}{l}26.790 * \\
(15.382)\end{array}$ & $\begin{array}{c}32.307^{* *} \\
(15.045)\end{array}$ & $\begin{array}{c}49.160 * * \\
(21.717)\end{array}$ & $\begin{array}{c}4.112 \\
(15.247)\end{array}$ \\
\hline Licensure $_{t-23}$ & $\begin{array}{c}-39.002 * * * \\
(10.595)\end{array}$ & $\begin{array}{c}14.528 \\
(14.226)\end{array}$ & $\begin{array}{c}16.713 \\
(14.345)\end{array}$ & $\begin{array}{c}20.334 \\
(14.049)\end{array}$ & $\begin{array}{l}24.958^{*} \\
(13.774)\end{array}$ & $\begin{array}{l}36.773^{*} \\
(20.262)\end{array}$ & $\begin{array}{c}-4.608 \\
(15.161)\end{array}$ \\
\hline Licensure $_{t-24}$ & $\begin{array}{c}-42.327 * * * \\
(11.929)\end{array}$ & $\begin{array}{c}8.045 \\
(15.825)\end{array}$ & $\begin{array}{c}6.961 \\
(16.152)\end{array}$ & $\begin{array}{c}10.976 \\
(15.590)\end{array}$ & $\begin{array}{c}16.951 \\
(15.388)\end{array}$ & $\begin{array}{c}26.399 \\
(22.231)\end{array}$ & $\begin{array}{l}-16.354 \\
(16.229)\end{array}$ \\
\hline Licensure $_{t-25}$ & $\begin{array}{c}-25.711^{* *} \\
(11.448)\end{array}$ & $\begin{array}{l}26.161^{*} \\
(14.716)\end{array}$ & $\begin{array}{l}27.006 * \\
(14.701)\end{array}$ & $\begin{array}{c}30.862 * * \\
(14.529)\end{array}$ & $\begin{array}{c}35.824 * * \\
(14.113)\end{array}$ & $\begin{array}{c}45.508 * * \\
(21.146)\end{array}$ & $\begin{array}{c}1.663 \\
(15.571)\end{array}$ \\
\hline Licensure $_{t-26}$ & $\begin{array}{c}-31.917 * * * \\
(11.312)\end{array}$ & $\begin{array}{c}19.584 \\
(15.149)\end{array}$ & $\begin{array}{c}18.471 \\
(15.520)\end{array}$ & $\begin{array}{c}22.020 \\
(15.025)\end{array}$ & $\begin{array}{l}27.394 * \\
(14.853)\end{array}$ & $\begin{array}{l}37.670^{*} \\
(21.992)\end{array}$ & $\begin{array}{c}-8.116 \\
(16.273)\end{array}$ \\
\hline Licensure $_{t-27}$ & $\begin{array}{c}-39.915 * * * \\
(10.024)\end{array}$ & $\begin{array}{c}15.018 \\
(13.573)\end{array}$ & $\begin{array}{c}14.614 \\
(13.716)\end{array}$ & $\begin{array}{c}17.970 \\
(13.376)\end{array}$ & $\begin{array}{l}23.258^{*} \\
(12.984)\end{array}$ & $\begin{array}{l}35.195^{*} \\
(20.020)\end{array}$ & $\begin{array}{c}-8.295 \\
(14.770)\end{array}$ \\
\hline Licensure $_{t-28}$ & $\begin{array}{c}-40.357 * * * \\
(13.182)\end{array}$ & $\begin{array}{c}14.273 \\
(16.135)\end{array}$ & $\begin{array}{c}14.464 \\
(16.325)\end{array}$ & $\begin{array}{c}18.704 \\
(15.939)\end{array}$ & $\begin{array}{c}24.442 \\
(15.623)\end{array}$ & $\begin{array}{l}35.799 * \\
(21.476)\end{array}$ & $\begin{array}{c}-10.079 \\
(16.763)\end{array}$ \\
\hline Licensure $_{t-29}$ & $\begin{array}{c}-58.043 * * * \\
(8.888)\end{array}$ & $\begin{array}{c}2.311 \\
(12.995)\end{array}$ & $\begin{array}{c}3.494 \\
(13.027)\end{array}$ & $\begin{array}{c}6.884 \\
(12.737)\end{array}$ & $\begin{array}{c}10.709 \\
(12.415)\end{array}$ & $\begin{array}{c}27.839 \\
(20.424)\end{array}$ & $\begin{array}{l}-19.824 \\
(15.517)\end{array}$ \\
\hline Licensure $_{t-30}$ & $\begin{array}{c}-44.443 * * * \\
(11.724)\end{array}$ & $\begin{array}{c}12.533 \\
(14.277)\end{array}$ & $\begin{array}{c}13.966 \\
(14.191)\end{array}$ & $\begin{array}{c}18.408 \\
(13.833)\end{array}$ & $\begin{array}{l}23.742 * \\
(13.359)\end{array}$ & $\begin{array}{c}37.093 \\
(22.539)\end{array}$ & $\begin{array}{l}-12.741 \\
(16.546)\end{array}$ \\
\hline Licensure $_{t-31 \mathrm{f}}$ & $\begin{array}{c}5.982 \\
(10.893)\end{array}$ & $\begin{array}{c}2.392 \\
(13.834)\end{array}$ & $\begin{array}{c}2.596 \\
(13.599)\end{array}$ & $\begin{array}{c}6.686 \\
(13.167)\end{array}$ & $\begin{array}{c}13.236 \\
(12.755)\end{array}$ & $\begin{array}{c}87.710 * * * \\
(21.859)\end{array}$ & $\begin{array}{l}-27.659 \\
(18.644)\end{array}$ \\
\hline idual Covariates & YES & YES & YES & YES & YES & YES & YES \\
\hline $\mathrm{FE}$ & NO & YES & YES & YES & YES & NO & YES \\
\hline jit SOC 2000 & NO & NO & YES & NO & NO & NO & NO \\
\hline sit SOC 2000 & NO & NO & NO & YES & NO & NO & NO \\
\hline it SOC 2000 & NO & NO & NO & NO & YES & NO & NO \\
\hline $\mathrm{FE}$ & YES & YES & YES & YES & YES & YES & YES \\
\hline $\mathrm{FE}$ & YES & YES & YES & YES & YES & YES & YES \\
\hline $\operatorname{doption}_{(\mathrm{t} 0 \sim \mathrm{t}+31 \mathrm{f})}=0$ & 0 & 0 & 0 & 0 & 0 & 8.58e-09 & 0 \\
\hline doption $_{(t+1 \sim t+6)}=0$ & 0.000548 & 0.474 & 0.434 & 0.515 & 0.641 & 0.832 & 0.128 \\
\hline uared & 0.088 & 0.110 & 0.116 & 0.140 & 0.154 & 0.105 & 0.194 \\
\hline rrvations & $11,240,956$ & $11,240,956$ & $11,240,956$ & $11,240,956$ & $11,240,956$ & $1,997,042$ & $1,997,042$ \\
\hline
\end{tabular}

Note: All models include indicators for gender, race (white vs. others), dummies for marital status (married, married but absent, separated/divorced/widowed vs. unmarried), years of education, potential experience and a quadratic function in potential experience; ${ }^{* * *}$ significant at the 0.01 level; ${ }^{* *}$ significant at the 0.05 level; * significant at the 0.1 level; standard errors are constructed using the heteroscedasticity robust covariance matrix that allows for clustering at the state-occupation level. 
Panel B. Occupations that Changed Regulation Status over the Period of Our Analysis

\begin{tabular}{|c|c|c|c|c|c|c|c|}
\hline \multirow{2}{*}{ Control Group: } & (1) & (2) & (3) & (4) & (5) & (6) & (7) \\
\hline & \multicolumn{5}{|c|}{$\begin{array}{l}\text { Relative to Individuals in Never Licensed Occupations Throughout } \\
\text { Our period of Analysis }\end{array}$} & \multicolumn{2}{|c|}{$\begin{array}{c}\text { Relative to Workers in } \\
\text { Universally Licensed } \\
\text { Occupations Prior to } \\
\text { States Passing Licensing } \\
\text { Statutes } \\
\end{array}$} \\
\hline Leads and Lags: & & & & & & & \\
\hline Licensure $_{t+6}$ & $\begin{array}{l}-66.840 * * \\
(27.872)\end{array}$ & $\begin{array}{l}-14.712 \\
(28.954)\end{array}$ & $\begin{array}{l}-12.769 \\
(28.744)\end{array}$ & $\begin{array}{l}-12.458 \\
(28.799)\end{array}$ & $\begin{array}{l}-13.147 \\
(28.897)\end{array}$ & $\begin{array}{l}-27.978 \\
(24.647)\end{array}$ & $\begin{array}{l}-20.635 \\
(22.750)\end{array}$ \\
\hline Licensure $_{t+5}$ & $\begin{array}{l}-78.598 * * * \\
(22.137)\end{array}$ & $\begin{array}{l}-35.910^{*} \\
(19.173)\end{array}$ & $\begin{array}{c}-36.994 * * \\
(18.424)\end{array}$ & $\begin{array}{l}-33.663^{*} \\
(18.284)\end{array}$ & $\begin{array}{l}-28.626 \\
(17.651)\end{array}$ & $\begin{array}{l}-22.763 \\
(14.582)\end{array}$ & $\begin{array}{c}-35.023 * * \\
(14.179)\end{array}$ \\
\hline Licensure $_{t+4}$ & $\begin{array}{l}-106.821^{* * *} \\
(34.141)\end{array}$ & $\begin{array}{c}-63.436^{* *} \\
(31.793)\end{array}$ & $\begin{array}{c}-63.522 * * \\
(30.934)\end{array}$ & $\begin{array}{c}-62.458 * * \\
(31.339)\end{array}$ & $\begin{array}{l}-56.651^{*} \\
(30.162)\end{array}$ & $\begin{array}{l}-44.929 * \\
(25.910)\end{array}$ & $\begin{array}{c}-57.172 * * \\
(25.582)\end{array}$ \\
\hline Licensure $_{t+3}$ & $\begin{array}{c}-80.062 * * * \\
(26.451)\end{array}$ & $\begin{array}{l}-31.518 \\
(24.499)\end{array}$ & $\begin{array}{l}-31.353 \\
(23.829)\end{array}$ & $\begin{array}{l}-30.237 \\
(23.465)\end{array}$ & $\begin{array}{c}-28.643 \\
(21.866)\end{array}$ & $\begin{array}{l}-33.999 * \\
(20.187)\end{array}$ & $\begin{array}{l}-35.979 * \\
(21.442)\end{array}$ \\
\hline Licensure $_{t+2}$ & $\begin{array}{c}-93.698 * * * \\
(27.155)\end{array}$ & $\begin{array}{c}-40.956 \\
(27.762)\end{array}$ & $\begin{array}{l}-43.058 \\
(27.059)\end{array}$ & $\begin{array}{l}-40.666 \\
(28.010)\end{array}$ & $\begin{array}{c}-37.109 \\
(25.892)\end{array}$ & $\begin{array}{l}-39.313^{*} \\
(23.446)\end{array}$ & $\begin{array}{c}-43.548 * \\
(24.161)\end{array}$ \\
\hline Licensure $_{t+1}$ & $\begin{array}{c}-77.315^{* * *} \\
(23.701)\end{array}$ & $\begin{array}{l}-16.132 \\
(25.001)\end{array}$ & $\begin{array}{l}-18.345 \\
(24.055)\end{array}$ & $\begin{array}{l}-17.255 \\
(23.821)\end{array}$ & $\begin{array}{l}-16.748 \\
(22.040)\end{array}$ & $\begin{array}{l}-29.574 \\
(19.079)\end{array}$ & $\begin{array}{l}-21.120 \\
(22.605)\end{array}$ \\
\hline Licensure $_{t+0}$ & $\begin{array}{c}-65.751 * * * \\
(20.703)\end{array}$ & $\begin{array}{l}-23.430 \\
(18.063)\end{array}$ & $\begin{array}{l}-21.832 \\
(18.513)\end{array}$ & $\begin{array}{l}-20.804 \\
(17.818)\end{array}$ & $\begin{array}{l}-14.844 \\
(17.506)\end{array}$ & $\begin{array}{c}-10.732 \\
(17.359)\end{array}$ & $\begin{array}{l}-24.926 \\
(16.266)\end{array}$ \\
\hline Licensure $_{t-1}$ & $\begin{array}{c}-50.144 * * * \\
(18.950)\end{array}$ & $\begin{array}{c}1.442 \\
(15.850)\end{array}$ & $\begin{array}{c}0.894 \\
(15.819)\end{array}$ & $\begin{array}{c}0.910 \\
(15.520)\end{array}$ & $\begin{array}{c}3.341 \\
(15.385)\end{array}$ & $\begin{array}{c}-1.633 \\
(14.152)\end{array}$ & $\begin{array}{c}-4.862 \\
(15.755)\end{array}$ \\
\hline Licensure $_{t-2}$ & $\begin{array}{c}-45.206 * * * \\
(13.731)\end{array}$ & $\begin{array}{c}-3.794 \\
(13.248)\end{array}$ & $\begin{array}{c}-2.135 \\
(13.490)\end{array}$ & $\begin{array}{c}-1.079 \\
(13.111)\end{array}$ & $\begin{array}{c}5.248 \\
(13.011)\end{array}$ & $\begin{array}{c}8.933 \\
(11.964)\end{array}$ & $\begin{array}{c}-5.470 \\
(12.326)\end{array}$ \\
\hline Licensure $_{t-3}$ & $\begin{array}{c}-42.824 * * * \\
(15.167)\end{array}$ & $\begin{array}{c}-0.896 \\
(13.537)\end{array}$ & $\begin{array}{c}-0.342 \\
(13.689)\end{array}$ & $\begin{array}{c}2.100 \\
(13.356)\end{array}$ & $\begin{array}{c}8.442 \\
(13.285)\end{array}$ & $\begin{array}{c}-1.764 \\
(11.941)\end{array}$ & $\begin{array}{l}-16.160 \\
(12.901)\end{array}$ \\
\hline Licensure $_{t-4}$ & $\begin{array}{l}-26.376 \\
(18.212)\end{array}$ & $\begin{array}{c}13.721 \\
(16.893)\end{array}$ & $\begin{array}{c}14.708 \\
(16.807)\end{array}$ & $\begin{array}{c}16.501 \\
(16.304)\end{array}$ & $\begin{array}{c}22.979 \\
(16.141)\end{array}$ & $\begin{array}{c}11.108 \\
(13.444)\end{array}$ & $\begin{array}{c}-6.653 \\
(14.467)\end{array}$ \\
\hline Licensure $_{t-5}$ & $\begin{array}{l}-18.008 \\
(17.364)\end{array}$ & $\begin{array}{c}22.894 \\
(15.587)\end{array}$ & $\begin{array}{c}23.075 \\
(15.644)\end{array}$ & $\begin{array}{c}24.983 \\
(15.499)\end{array}$ & $\begin{array}{c}31.457 * * \\
(15.593)\end{array}$ & $\begin{array}{c}19.375 \\
(12.781)\end{array}$ & $\begin{array}{c}1.443 \\
(14.207)\end{array}$ \\
\hline Licensure $_{t-6}$ & $\begin{array}{l}-15.841 \\
(15.463)\end{array}$ & $\begin{array}{l}23.808^{*} \\
(13.463)\end{array}$ & $\begin{array}{l}23.777^{*} \\
(13.501)\end{array}$ & $\begin{array}{c}26.622 * * \\
(13.171)\end{array}$ & $\begin{array}{c}33.603^{* *} \\
(13.156)\end{array}$ & $\begin{array}{c}22.702 * * \\
(10.494)\end{array}$ & $\begin{array}{c}3.278 \\
(11.780)\end{array}$ \\
\hline Licensure $_{t-7}$ & $\begin{array}{c}-22.768 * * \\
(11.321)\end{array}$ & $\begin{array}{l}19.489 * \\
(11.594)\end{array}$ & $\begin{array}{c}18.964 \\
(11.659)\end{array}$ & $\begin{array}{l}21.217^{*} \\
(11.369)\end{array}$ & $\begin{array}{c}26.277 * * \\
(11.397)\end{array}$ & $\begin{array}{l}11.685 \\
(9.566)\end{array}$ & $\begin{array}{c}-3.240 \\
(10.892)\end{array}$ \\
\hline Licensure $_{t-8}$ & $\begin{array}{l}-19.789 \\
(14.006)\end{array}$ & $\begin{array}{c}20.617 \\
(13.828)\end{array}$ & $\begin{array}{c}20.535 \\
(13.841)\end{array}$ & $\begin{array}{l}23.068^{*} \\
(13.427)\end{array}$ & $\begin{array}{c}29.823^{* *} \\
(13.315)\end{array}$ & $\begin{array}{c}14.594 \\
(11.305)\end{array}$ & $\begin{array}{c}-4.207 \\
(13.296)\end{array}$ \\
\hline Licensure $_{t-9}$ & $\begin{array}{l}-10.631 \\
(11.997)\end{array}$ & $\begin{array}{c}33.934 * * * \\
(11.280)\end{array}$ & $\begin{array}{c}33.434 * * * \\
(11.363)\end{array}$ & $\begin{array}{c}35.508^{* * *} \\
(11.234)\end{array}$ & $\begin{array}{c}40.605^{* * *} \\
(11.268)\end{array}$ & $\begin{array}{c}21.403 * * \\
(10.098)\end{array}$ & $\begin{array}{c}7.340 \\
(11.389)\end{array}$ \\
\hline Licensure $_{t-10}$ & $\begin{array}{c}8.921 \\
(16.842)\end{array}$ & $\begin{array}{c}47.574 * * * \\
(16.441)\end{array}$ & $\begin{array}{c}47.468 * * * \\
(16.362)\end{array}$ & $\begin{array}{c}49.992 * * * \\
(16.041)\end{array}$ & $\begin{array}{c}56.019 * * * \\
(15.821)\end{array}$ & $\begin{array}{c}38.396 * * * \\
(12.742)\end{array}$ & $\begin{array}{c}17.102 \\
(15.045)\end{array}$ \\
\hline Licensure $_{t-11}$ & $\begin{array}{c}-1.846 \\
(15.950)\end{array}$ & $\begin{array}{c}43.153 * * * \\
(16.393)\end{array}$ & $\begin{array}{c}42.524 * * * \\
(16.277)\end{array}$ & $\begin{array}{c}43.684 * * * \\
(16.174)\end{array}$ & $\begin{array}{c}48.900 * * * \\
(16.102)\end{array}$ & $\begin{array}{l}25.254^{*} \\
(13.232)\end{array}$ & $\begin{array}{c}11.626 \\
(15.224)\end{array}$ \\
\hline Licensure $_{t-12}$ & $\begin{array}{c}9.520 \\
(16.632)\end{array}$ & $\begin{array}{c}48.562^{* * *} \\
(17.566)\end{array}$ & $\begin{array}{c}48.569 * * * \\
(17.664)\end{array}$ & $\begin{array}{c}51.488 * * * \\
(17.366)\end{array}$ & $\begin{array}{c}57.299 * * * \\
(17.000)\end{array}$ & $\begin{array}{c}35.080^{* * *} \\
(11.756)\end{array}$ & $\begin{array}{c}14.953 \\
(13.676)\end{array}$ \\
\hline Licensure $_{t-13}$ & $\begin{array}{c}17.649 \\
(13.963)\end{array}$ & $\begin{array}{c}59.037 * * * \\
(15.957)\end{array}$ & $\begin{array}{c}59.188 * * * \\
(15.927)\end{array}$ & $\begin{array}{c}61.395 * * * \\
(15.552)\end{array}$ & $\begin{array}{c}67.299 * * * \\
(15.245)\end{array}$ & $\begin{array}{c}39.261^{* * *} \\
(11.596)\end{array}$ & $\begin{array}{c}21.671 \\
(13.602)\end{array}$ \\
\hline Licensure $_{t-14}$ & $\begin{array}{c}17.887 \\
(15.999)\end{array}$ & $\begin{array}{c}55.792^{* * *} \\
(18.381)\end{array}$ & $\begin{array}{c}56.080 * * * \\
(18.282)\end{array}$ & $\begin{array}{c}58.217 * * * \\
(17.851)\end{array}$ & $\begin{array}{c}64.582 * * * \\
(17.424)\end{array}$ & $\begin{array}{c}37.997 * * * \\
(13.306)\end{array}$ & $\begin{array}{c}16.779 \\
(15.399)\end{array}$ \\
\hline Licensure $_{t-15}$ & $\begin{array}{l}32.375^{*} \\
(16.942)\end{array}$ & $\begin{array}{c}72.679 * * * \\
(18.757)\end{array}$ & $\begin{array}{c}72.850 * * * \\
(18.826)\end{array}$ & $\begin{array}{c}75.058^{* * *} \\
(18.462)\end{array}$ & $\begin{array}{c}81.149 * * * \\
(18.119)\end{array}$ & $\begin{array}{c}50.489 * * * \\
(14.360)\end{array}$ & $\begin{array}{l}31.469 * \\
(16.205)\end{array}$ \\
\hline Licensure $_{t-16}$ & $\begin{array}{c}38.819 * * \\
(19.581)\end{array}$ & $\begin{array}{c}78.549 * * * \\
(21.348)\end{array}$ & $\begin{array}{c}78.108 * * * \\
(21.541)\end{array}$ & $\begin{array}{c}80.976 * * * \\
(20.741)\end{array}$ & $\begin{array}{c}87.236 * * * \\
(20.403)\end{array}$ & $\begin{array}{c}55.889 * * * \\
(15.794)\end{array}$ & $\begin{array}{c}36.284^{* *} \\
(17.263)\end{array}$ \\
\hline
\end{tabular}




\begin{tabular}{|c|c|c|c|c|c|c|c|}
\hline Licensure $_{t-17}$ & $\begin{array}{c}20.599 \\
(21.818)\end{array}$ & $\begin{array}{c}63.806^{* * *} \\
(22.589)\end{array}$ & $\begin{array}{c}63.271 * * * \\
(22.786)\end{array}$ & $\begin{array}{c}65.611 * * * \\
(22.554)\end{array}$ & $\begin{array}{c}70.841 * * * \\
(22.482)\end{array}$ & $\begin{array}{c}41.696 * * \\
(17.968)\end{array}$ & $\begin{array}{c}26.741 \\
(18.696)\end{array}$ \\
\hline Licensure $_{t-18}$ & $\begin{array}{c}37.262 \\
(23.024)\end{array}$ & $\begin{array}{c}79.964 * * * \\
(23.801)\end{array}$ & $\begin{array}{c}78.877 * * * \\
(24.327)\end{array}$ & $\begin{array}{c}82.119 * * * \\
(23.477)\end{array}$ & $\begin{array}{c}88.269 * * * \\
(23.161)\end{array}$ & $\begin{array}{c}49.625 * * \\
(19.664)\end{array}$ & $\begin{array}{l}33.379 * \\
(19.622)\end{array}$ \\
\hline Licensure $_{t-19}$ & $\begin{array}{c}-4.090 \\
(12.736)\end{array}$ & $\begin{array}{c}51.325^{* * *} \\
(14.938)\end{array}$ & $\begin{array}{c}50.022 * * * \\
(15.135)\end{array}$ & $\begin{array}{c}52.813^{* * *} \\
(14.985)\end{array}$ & $\begin{array}{c}56.635 * * * \\
(15.212)\end{array}$ & $\begin{array}{c}23.480 \\
(15.092)\end{array}$ & $\begin{array}{c}23.351 \\
(14.661)\end{array}$ \\
\hline Licensure $_{t-20}$ & $\begin{array}{c}1.989 \\
(14.736)\end{array}$ & $\begin{array}{c}44.444 * * \\
(17.767)\end{array}$ & $\begin{array}{c}42.813 * * \\
(18.135)\end{array}$ & $\begin{array}{c}46.653 * * * \\
(17.273)\end{array}$ & $\begin{array}{c}52.847 * * * \\
(17.139)\end{array}$ & $\begin{array}{c}25.888 \\
(17.223)\end{array}$ & $\begin{array}{c}11.042 \\
(17.265)\end{array}$ \\
\hline Licensure $_{t-21}$ & $\begin{array}{c}-45.219 * * * \\
(14.365)\end{array}$ & $\begin{array}{c}10.473 \\
(17.052)\end{array}$ & $\begin{array}{c}10.565 \\
(16.875)\end{array}$ & $\begin{array}{c}12.748 \\
(16.821)\end{array}$ & $\begin{array}{c}17.672 \\
(17.026)\end{array}$ & $\begin{array}{l}-12.662 \\
(16.074)\end{array}$ & $\begin{array}{l}-10.780 \\
(18.187)\end{array}$ \\
\hline Licensure $_{t-22}$ & $\begin{array}{l}-21.354^{*} \\
(12.852)\end{array}$ & $\begin{array}{c}22.343 \\
(15.665)\end{array}$ & $\begin{array}{c}22.303 \\
(15.857)\end{array}$ & $\begin{array}{l}25.688^{*} \\
(15.452)\end{array}$ & $\begin{array}{c}31.521 * * \\
(15.115)\end{array}$ & $\begin{array}{c}10.925 \\
(14.902)\end{array}$ & $\begin{array}{c}-0.750 \\
(15.011)\end{array}$ \\
\hline Licensure $_{t-23}$ & $\begin{array}{c}-34.238 * * * \\
(10.842)\end{array}$ & $\begin{array}{c}11.921 \\
(14.398)\end{array}$ & $\begin{array}{c}14.244 \\
(14.512)\end{array}$ & $\begin{array}{c}18.018 \\
(14.146)\end{array}$ & $\begin{array}{l}22.971 * \\
(13.881)\end{array}$ & $\begin{array}{c}-1.996 \\
(14.947)\end{array}$ & $\begin{array}{l}-10.432 \\
(15.604)\end{array}$ \\
\hline Licensure $_{t-24}$ & $\begin{array}{c}-34.917 * * * \\
(12.056)\end{array}$ & $\begin{array}{c}7.911 \\
(15.839)\end{array}$ & $\begin{array}{c}6.891 \\
(16.169)\end{array}$ & $\begin{array}{c}11.011 \\
(15.561)\end{array}$ & $\begin{array}{c}17.152 \\
(15.352)\end{array}$ & $\begin{array}{c}-6.291 \\
(16.046)\end{array}$ & $\begin{array}{l}-19.471 \\
(16.182)\end{array}$ \\
\hline Licensure $_{t-25}$ & $\begin{array}{c}-20.289 * \\
(11.441)\end{array}$ & $\begin{array}{l}24.777 * \\
(14.731)\end{array}$ & $\begin{array}{l}25.749 * \\
(14.713)\end{array}$ & $\begin{array}{c}29.753^{* *} \\
(14.488)\end{array}$ & $\begin{array}{c}34.986 * * \\
(14.062)\end{array}$ & $\begin{array}{c}6.463 \\
(14.952)\end{array}$ & $\begin{array}{c}-4.577 \\
(15.420)\end{array}$ \\
\hline Licensure $_{t-26}$ & $\begin{array}{c}-25.343^{* *} \\
(11.373)\end{array}$ & $\begin{array}{c}19.316 \\
(15.106)\end{array}$ & $\begin{array}{c}18.268 \\
(15.474)\end{array}$ & $\begin{array}{c}21.910 \\
(14.936)\end{array}$ & $\begin{array}{l}27.434 * \\
(14.753)\end{array}$ & $\begin{array}{c}-0.734 \\
(15.742)\end{array}$ & $\begin{array}{l}-12.729 \\
(16.040)\end{array}$ \\
\hline Licensure $_{t-27}$ & $\begin{array}{c}-33.794 * * * \\
(10.080)\end{array}$ & $\begin{array}{c}14.603 \\
(13.586)\end{array}$ & $\begin{array}{c}14.250 \\
(13.729)\end{array}$ & $\begin{array}{c}17.679 \\
(13.341)\end{array}$ & $\begin{array}{l}23.117 * \\
(12.928)\end{array}$ & $\begin{array}{c}-3.941 \\
(13.952)\end{array}$ & $\begin{array}{l}-12.209 \\
(14.857)\end{array}$ \\
\hline Licensure $_{t-28}$ & $\begin{array}{c}-34.739 * * * \\
(13.395)\end{array}$ & $\begin{array}{c}14.082 \\
(16.088)\end{array}$ & $\begin{array}{c}14.337 \\
(16.278)\end{array}$ & $\begin{array}{c}18.662 \\
(15.857)\end{array}$ & $\begin{array}{c}24.559 \\
(15.522)\end{array}$ & $\begin{array}{c}-8.935 \\
(15.884)\end{array}$ & $\begin{array}{l}-16.954 \\
(16.451)\end{array}$ \\
\hline Licensure $_{t-29}$ & $\begin{array}{c}-52.662 * * * \\
(8.869)\end{array}$ & $\begin{array}{c}4.697 \\
(12.679)\end{array}$ & $\begin{array}{c}5.969 \\
(12.703)\end{array}$ & $\begin{array}{c}9.367 \\
(12.377)\end{array}$ & $\begin{array}{c}13.403 \\
(11.999)\end{array}$ & $\begin{array}{l}-19.596 \\
(14.857)\end{array}$ & $\begin{array}{l}-19.737 \\
(14.749)\end{array}$ \\
\hline Licensure $_{t-30}$ & $\begin{array}{c}-40.106 * * * \\
(11.896)\end{array}$ & $\begin{array}{c}11.999 \\
(14.258)\end{array}$ & $\begin{array}{c}13.484 \\
(14.171)\end{array}$ & $\begin{array}{c}18.031 \\
(13.776)\end{array}$ & $\begin{array}{l}23.565 * \\
(13.285)\end{array}$ & $\begin{array}{l}-13.380 \\
(18.250)\end{array}$ & $\begin{array}{l}-19.552 \\
(16.560)\end{array}$ \\
\hline Licensure $_{t-31 \mathrm{f}}$ & $\begin{array}{c}-47.965 * * * \\
(6.223)\end{array}$ & $\begin{array}{c}2.795 \\
(13.790)\end{array}$ & $\begin{array}{c}3.016 \\
(13.568)\end{array}$ & $\begin{array}{c}7.191 \\
(13.067)\end{array}$ & $\begin{array}{c}13.846 \\
(12.626)\end{array}$ & $\begin{array}{l}-16.525 \\
(14.179)\end{array}$ & $\begin{array}{l}-30.347 \\
(18.975)\end{array}$ \\
\hline Individual Covariates & YES & YES & YES & YES & YES & YES & YES \\
\hline OCC FE & NO & YES & YES & YES & YES & NO & YES \\
\hline 1-digit SOC 2000 & NO & NO & YES & NO & NO & NO & NO \\
\hline 2-digit SOC 2000 & NO & NO & NO & YES & NO & NO & NO \\
\hline 3-digit SOC 2000 & NO & NO & NO & NO & YES & NO & NO \\
\hline Year FE & YES & YES & YES & YES & YES & YES & YES \\
\hline State FE & YES & YES & YES & YES & YES & YES & YES \\
\hline $\mathrm{H}_{0}$ : $\operatorname{adoption}_{(\mathrm{t} 0 \sim \mathrm{t}+31 \mathrm{f})}=0$ & 0 & 0 & 6.99e-11 & 0 & 0 & $1.03 e-07$ & $2.79 \mathrm{e}-08$ \\
\hline $\mathrm{H}_{0}$ : adoption $_{(\mathrm{t}+1 \sim \mathrm{t}+6)}=0$ & 0.00304 & 0.477 & 0.441 & 0.519 & 0.654 & 0.469 & 0.262 \\
\hline R-squared & 0.082 & 0.083 & 0.090 & 0.116 & 0.132 & 0.055 & 0.065 \\
\hline Observations & $10,829,059$ & $10,829,059$ & $10,829,059$ & $10,829,059$ & $10,829,059$ & $1,585,145$ & $1,585,145$ \\
\hline
\end{tabular}

Note: All models include indicators for gender, race (white vs. others), dummies for marital status (married, married but absent, separated/divorced/widowed vs. unmarried), years of education, potential experience and a quadratic function in potential experience; *** significant at the 0.01 level; ** significant at the 0.05 level; * significant at the 0.1 level; standard errors are constructed using the heteroscedasticity robust covariance matrix that allows for clustering at the state-occupation level. 
Appendix 8. Table. Matching Summary-Licensure Effects

Panel A. 13 Universally Licensed Occupations

\begin{tabular}{|c|c|c|c|c|}
\hline Control Group & \multicolumn{2}{|c|}{$\begin{array}{c}\text { Relative to Individuals in } \\
\text { Never Licensed Occupations } \\
\text { Throughout Our Period of } \\
\text { Analysis }\end{array}$} & \multicolumn{2}{|c|}{$\begin{array}{l}\text { Relative to Unlicensed } \\
\text { Workers in Universally } \\
\text { Licensed Occupations Prior } \\
\text { to States Passing Licensing } \\
\text { Statutes }\end{array}$} \\
\hline Number of Strata & \multicolumn{2}{|c|}{88} & \multicolumn{2}{|c|}{88} \\
\hline \multirow[t]{2}{*}{ Number of Matched Strata } & \multicolumn{2}{|c|}{87} & \multicolumn{2}{|c|}{85} \\
\hline & Control & Treated & Control & Treated \\
\hline All & $9,305,866$ & $1,935,610$ & 61,491 & $1,935,610$ \\
\hline Matched & $9,305,866$ & $1,935,610$ & 61,491 & $1,935,559$ \\
\hline Unmatched & 0 & 0 & 0 & 51 \\
\hline
\end{tabular}

Note: The models perform coarsened exact matching on experience and marital status, and perform exact matching on race (white vs. others) and gender.

Panel B. Occupations that Changed Regulation Status over the Period of Our Analysis

\begin{tabular}{|c|c|c|c|c|}
\hline Control Group & \multicolumn{2}{|c|}{$\begin{array}{c}\text { Relative to Individuals in } \\
\text { Never Licensed Occupations } \\
\text { Throughout Our Period of } \\
\text { Analysis }\end{array}$} & \multicolumn{2}{|c|}{$\begin{array}{c}\text { Relative to Unlicensed } \\
\text { Workers in Universally } \\
\text { Licensed Occupations Prior } \\
\text { to States Passing Licensing } \\
\text { Statutes }\end{array}$} \\
\hline Number of Strata & \multicolumn{2}{|c|}{88} & \multicolumn{2}{|c|}{88} \\
\hline Number of Matched Strata & \multicolumn{2}{|c|}{87} & \multicolumn{2}{|c|}{85} \\
\hline & Control & Treated & Control & Treated \\
\hline All & $9,305,866$ & $1,523,706$ & 61,491 & $1,523,706$ \\
\hline Matched & $9,305,866$ & $1,523,706$ & 61,491 & 1523,659 \\
\hline Unmatched & 0 & 0 & 0 & 47 \\
\hline
\end{tabular}

Note: The models perform coarsened exact matching on experience and marital status, and perform exact matching on race (white vs. others) and gender. 


\section{Panel C. Grandfathering}

\begin{tabular}{l|cc|cc}
\hline Control Group & $\begin{array}{c}\text { Relative to Individuals in } \\
\text { Never Licensed Occupations } \\
\text { Throughout Our Period of } \\
\text { Analysis }\end{array}$ & $\begin{array}{c}\text { Relative to Unlicensed } \\
\text { Workers in Universally } \\
\text { Licensed Occupations Prior } \\
\text { to States Passing Licensing } \\
\text { Statutes }\end{array}$ \\
\hline Number of Strata & \multicolumn{2}{|c|}{232} & \multicolumn{2}{|c}{232} \\
Number of Matched Strata & \multicolumn{2}{|c|}{231} & Control & Treated \\
\hline All & Control & Treated & 61,491 & 249,768 \\
Matched & $9,305,866$ & 249,768 & 61,490 & 249,735 \\
Unmatched & $9,303,185$ & 249,786 & 23 & 33 \\
\hline
\end{tabular}

Note: The models perform coarsened exact matching on education, experience, and marital status, and perform exact matching on race (white vs. others) and gender. 
Appendix Table 9. Matching Summary-Duration Effects

Panel A. 13 Universally Licensed Occupations

\begin{tabular}{|c|c|c|c|c|c|c|c|c|c|}
\hline Control Group & \multicolumn{9}{|c|}{ Relative to Individuals in Never Licensed Occupations Throughout Our Period of Analysis } \\
\hline Number of Strata & \multicolumn{9}{|l|}{88} \\
\hline Number of Matched Strata & \multicolumn{9}{|l|}{78} \\
\hline & Control & {$[0,3]$} & {$[4,10]$} & {$[11,20]$} & {$[21,30]$} & {$[31,40]$} & {$[41,50]$} & {$[51,100]$} & $\geq 101$ \\
\hline All & $9,305,866$ & 40,175 & 62,133 & 145,543 & 167,228 & 238,115 & 233,172 & 689,107 & 360,137 \\
\hline Matched & $9,292,106$ & 40,169 & 62,125 & 145,529 & 167,212 & 238,088 & 233,157 & 689,010 & 360,119 \\
\hline Unmatched & 13,760 & 6 & 8 & 14 & 16 & 27 & 15 & 97 & 18 \\
\hline
\end{tabular}

Note: The models perform coarsened exact matching on experience and marital status, and perform exact matching on race (white vs. others) and gender.

\begin{tabular}{|c|c|c|c|c|c|c|c|c|c|}
\hline Control Group & \multicolumn{9}{|c|}{ Relative to Unlicensed Workers in Universally Licensed Occupations Prior to States Passing Licensing Statutes } \\
\hline Number of Strata & \multicolumn{9}{|l|}{88} \\
\hline \multirow[t]{2}{*}{ Number of Matched Strata } & \multicolumn{9}{|l|}{78} \\
\hline & Control & {$[0,3]$} & {$[4,10]$} & {$[11,20]$} & {$[21,30]$} & {$[31,40]$} & {$[41,50]$} & {$[51,100]$} & $\geq 101$ \\
\hline All & 61,491 & 40,175 & 62,133 & 145,543 & 167,228 & 238,115 & 233,172 & 689,107 & 360,137 \\
\hline Matched & 61,477 & 40,169 & 62,125 & 145,529 & 167,212 & 238,088 & 233,157 & 689,010 & 360,119 \\
\hline Unmatched & 14 & 6 & 8 & 14 & 16 & 27 & 15 & 97 & 18 \\
\hline
\end{tabular}

Note: The models perform coarsened exact matching on experience and marital status, and perform exact matching on race (white vs. others) and gender. 
Panel B. Occupations that Changed Regulation Status over the Period of Our Analysis

\begin{tabular}{|c|c|c|c|c|c|c|c|c|c|}
\hline Control Group & \multicolumn{9}{|c|}{ Relative to Individuals in Never Licensed Occupations Throughout Our Period of Analysis } \\
\hline Number of Strata & \multicolumn{9}{|l|}{88} \\
\hline \multirow[t]{2}{*}{ Number of Matched Strata } & \multicolumn{9}{|l|}{78} \\
\hline & Control & {$[0,3]$} & {$[4,10]$} & {$[11,20]$} & {$[21,30]$} & {$[31,40]$} & {$[41,50]$} & {$[51,100]$} & $\geq 101$ \\
\hline All & $9,305,866$ & 40,173 & 62,112 & 145,412 & 166,502 & 236,089 & 227,181 & 550,689 & 955,548 \\
\hline Matched & 9,292,106 & 40,167 & 62,104 & 145,398 & 166,486 & 236,064 & 227,166 & 550,615 & 955,31 \\
\hline Unmatched & 13,760 & 6 & 8 & 14 & 16 & 25 & 15 & 74 & 17 \\
\hline
\end{tabular}

Note: The models perform coarsened exact matching on experience and marital status, and perform exact matching on race (white vs. others) and gender.

\begin{tabular}{|c|c|c|c|c|c|c|c|c|c|}
\hline Control Group & \multicolumn{9}{|c|}{ Relative to Unlicensed Workers in Universally Licensed Occupations Prior to States Passing Licensing Statutes } \\
\hline Number of Strata & \multicolumn{9}{|l|}{88} \\
\hline \multirow[t]{2}{*}{ Number of Matched Strata } & \multicolumn{9}{|l|}{78} \\
\hline & Control & {$[0,3]$} & {$[4,10]$} & {$[11,20]$} & {$[21,30]$} & {$[31,40]$} & {$[41,50]$} & {$[51,100]$} & $\geq 101$ \\
\hline All & 61,491 & 40,173 & 62,112 & 145,412 & 166,502 & 236,089 & 227,181 & 550,689 & 95,548 \\
\hline Matched & 61,477 & 40,167 & 62,104 & 145,398 & 166,486 & 236,064 & 227,166 & 550,615 & 95.531 \\
\hline Unmatched & 14 & 6 & 8 & 14 & 16 & 25 & 15 & 74 & 17 \\
\hline
\end{tabular}

Note: The models perform coarsened exact matching on experience and marital status, and perform exact matching on race (white vs. others) and gender. 
Panel C. Grandfathering

\begin{tabular}{|c|c|c|c|c|c|c|c|}
\hline Control Group & \multicolumn{7}{|c|}{ Relative to Individuals in Never Licensed Occupations Throughout Our Period of Analysis } \\
\hline Number of Strata & 232 & & & & & & \\
\hline \multirow[t]{2}{*}{ Number of Matched Strata } & 29 & & & & & & \\
\hline & Control & {$[0,3]$} & {$[4,10]$} & {$[11,20]$} & {$[21,30]$} & {$[31,40]$} & {$[41,50]$} \\
\hline All & $9,305,866$ & 38,594 & 49,607 & 86,158 & 50,495 & 23,425 & 1,489 \\
\hline Matched & 594,285 & 544 & 1,098 & 3,169 & 3,533 & 6,434 & 1,429 \\
\hline Unmatched & $8,711,581$ & 38,050 & 48,509 & 82,989 & 46,962 & 16,991 & 60 \\
\hline
\end{tabular}

Note: The models perform coarsened exact matching on education, experience, and marital status, and perform exact matching on race (white vs. others) and gender.

\begin{tabular}{|c|c|c|c|c|c|c|c|}
\hline Control Group & \multicolumn{7}{|c|}{ Relative to Unlicensed Workers in Universally Licensed Occupations Prior to States Passing Licensing Statutes } \\
\hline Number of Strata & \multirow{2}{*}{\multicolumn{7}{|c|}{$\begin{array}{l}232 \\
29\end{array}$}} \\
\hline \multirow[t]{2}{*}{ Number of Matched Strata } & & & & & & & \\
\hline & Control & {$[0,3]$} & {$[4,10]$} & {$[11,20]$} & {$[21,30]$} & {$[31,40]$} & {$[41,50]$} \\
\hline All & 61,491 & 38,594 & 49,607 & 86,158 & 50,495 & 23,425 & 1,489 \\
\hline Matched & 917 & 544 & 1,098 & 3,169 & 3,533 & 6,434 & 1,429 \\
\hline Unmatched & 60,574 & 38,050 & 48,509 & 82,989 & 46,962 & 16,991 & 60 \\
\hline
\end{tabular}

Note: The models perform coarsened exact matching on education, experience, and marital status, and perform exact matching on race (white vs. others) and gender. 
Appendix Table 10. Difference-in-Differences Coarsened Exact Matching Estimate of Effects of Occupational Licensing Duration Panel A. 13 Universally Licensed Occupations

\begin{tabular}{|c|c|c|c|c|c|c|c|c|}
\hline & (1) & (2) & (3) & (4) & (5) & (6) & (7) & (8) \\
\hline Control Group: & \multicolumn{4}{|c|}{$\begin{array}{c}\text { Relative to Individuals in Never Licensed Occupations } \\
\text { Throughout Our period of Analysis }\end{array}$} & \multicolumn{4}{|c|}{$\begin{array}{l}\text { Relative to Unlicensed Workers in Universally Licensed } \\
\text { Occupations Prior to States Passing Licensing Statutes }\end{array}$} \\
\hline VARIABLES & \multicolumn{2}{|c|}{ Wage } & \multicolumn{2}{|c|}{ Hour } & \multicolumn{2}{|c|}{ Wage } & \multicolumn{2}{|c|}{ Hour } \\
\hline Licensure & $\begin{array}{c}0.0844 * * * \\
(0.021)\end{array}$ & & $\begin{array}{l}51.7443 * * * \\
(14.198)\end{array}$ & & $\begin{array}{c}0.2638 * * * \\
(0.019)\end{array}$ & & $\begin{array}{l}111.0705^{* * *} \\
\quad(18.124)\end{array}$ & \\
\hline Duration $\in[0.3]$ & & $\begin{array}{c}0.0460 * * * \\
(0.013)\end{array}$ & & $\begin{array}{l}34.4784 * * * \\
(8.947)\end{array}$ & & $\begin{array}{c}0.0308^{* *} \\
(0.014)\end{array}$ & & $\begin{array}{l}52.0785^{* * *} \\
(9.423)\end{array}$ \\
\hline Duration $\in[4.10]$ & & $\begin{array}{c}0.0438 * * * \\
(0.015)\end{array}$ & & $\begin{array}{c}51.0785^{* * *} \\
(12.012)\end{array}$ & & $\begin{array}{l}0.0078 \\
(0.015)\end{array}$ & & $\begin{array}{l}75.2631 * * * \\
(10.150)\end{array}$ \\
\hline Duration $\in[11.20]$ & & $\begin{array}{l}0.0270 \\
(0.022)\end{array}$ & & $\begin{array}{c}81.8412 * * * \\
(18.588)\end{array}$ & & $\begin{array}{l}0.0116 \\
(0.023)\end{array}$ & & $\begin{array}{l}106.2512 * * * \\
\quad(16.921)\end{array}$ \\
\hline Duration $\in[21.30]$ & & $\begin{array}{c}0.0554^{* *} \\
(0.023)\end{array}$ & & $\begin{array}{l}41.3530 * * * \\
(15.408)\end{array}$ & & $\begin{array}{l}0.1384 * * * \\
(0.034)\end{array}$ & & $\begin{array}{l}72.8255^{* * *} \\
(17.995)\end{array}$ \\
\hline Duration $\in[31.40]$ & & $\begin{array}{l}0.0804 * * * \\
(0.024)\end{array}$ & & $\begin{array}{l}39.6132 * * \\
(15.625)\end{array}$ & & $\begin{array}{l}0.2791^{* * *} \\
(0.036)\end{array}$ & & $\begin{array}{l}55.9759 * * * \\
(18.535)\end{array}$ \\
\hline Duration $\in[41.50]$ & & $\begin{array}{c}0.0818^{* * *} \\
(0.024)\end{array}$ & & $\begin{array}{c}36.2460 * * \\
(15.950)\end{array}$ & & $\begin{array}{l}0.3348 * * * \\
(0.034)\end{array}$ & & $\begin{array}{c}47.9744 * * * \\
(17.392)\end{array}$ \\
\hline Duration $\in[51.100]$ & & $\begin{array}{l}0.1333 * * * \\
(0.026)\end{array}$ & & $\begin{array}{l}23.0874 \\
(17.664)\end{array}$ & & $\begin{array}{l}0.4056^{* * *} \\
(0.033)\end{array}$ & & $\begin{array}{l}96.6841 * * * \\
(18.372)\end{array}$ \\
\hline Duration $>100$ & & $\begin{array}{l}0.1731 * * * \\
(0.029)\end{array}$ & & $\begin{array}{l}27.9744 \\
(20.012)\end{array}$ & & $\begin{array}{c}0.7204^{* * *} \\
(0.041)\end{array}$ & & $\begin{array}{c}310.8649 * * * \\
(30.480)\end{array}$ \\
\hline Individual Covariates & YES & YES & YES & YES & YES & YES & YES & YES \\
\hline OCC FE & YES & YES & YES & YES & NO & NO & NO & NO \\
\hline Year FE & YES & YES & YES & YES & YES & YES & YES & YES \\
\hline State FE & YES & YES & YES & YES & YES & YES & YES & YES \\
\hline 1-digit SOC 2000 & NO & NO & $\mathrm{NO}$ & $\mathrm{NO}$ & $\mathrm{NO}$ & $\mathrm{NO}$ & NO & $\mathrm{NO}$ \\
\hline 2-digit SOC 2000 & NO & NO & $\mathrm{NO}$ & $\mathrm{NO}$ & $\mathrm{NO}$ & $\mathrm{NO}$ & NO & $\mathrm{NO}$ \\
\hline 3-digit SOC 2000 & YES & YES & YES & YES & $\mathrm{NO}$ & $\mathrm{NO}$ & $\mathrm{NO}$ & NO \\
\hline $\mathrm{H}_{0}$ : All Duration Dummies $=0$ & & 0 & & 0.00163 & & 0 & & 0 \\
\hline R-squared & 0.441 & 0.435 & 0.134 & 0.133 & 0.272 & 0.359 & 0.068 & 0.100 \\
\hline Observations & $11,240,956$ & $11,226,995$ & $11,240,956$ & $11,226,995$ & $1,996,991$ & $1,996,827$ & $1,996,991$ & $1,996,827$ \\
\hline
\end{tabular}

Note: All models perform coarsened exact matching on experience and marital status, and perform exact matching on race (white vs. others) and gender. Since some imbalances may still exist because we used only a few variables in the exact matching, we try to adjust for the remaining imbalances by controlling for actual values of the covariates in a regression.; *** significant at the 0.01 level; ** significant at the 0.05 level; * significant at the 0.1 level; standard errors are constructed using the heteroscedasticity robust covariance matrix that allows for clustering at the state-occupation level. 
Panel B. Occupations that Changed Regulation Status over the Period of Our Analysis

\begin{tabular}{|c|c|c|c|c|c|c|c|c|}
\hline & $(1)$ & $(2)$ & (3) & (4) & (5) & $(6)$ & $(7)$ & $(8)$ \\
\hline Control Group: & \multicolumn{4}{|c|}{$\begin{array}{c}\text { Relative to Individuals in Never Licensed Occupations } \\
\text { Throughout Our Period of Analysis }\end{array}$} & \multicolumn{4}{|c|}{$\begin{array}{l}\text { Relative to Unlicensed Workers in Universally Licensed } \\
\text { Occupations Prior to States Passing Licensing Statutes }\end{array}$} \\
\hline VARIABLES & \multicolumn{2}{|c|}{ Wage } & \multicolumn{2}{|c|}{ Hour } & \multicolumn{2}{|c|}{ Wage } & \multicolumn{2}{|c|}{ Hour } \\
\hline Licensure & $0.0991 * * *$ & & $56.6552 * * *$ & & $0.1861 * * *$ & & $\begin{array}{c}45.5282 * * * \\
(12.783)\end{array}$ & \\
\hline Duration $\in[0.3]$ & & $\begin{array}{c}0.0517 * * * \\
(0.013)\end{array}$ & & $\begin{array}{l}33.4418^{* * *} \\
(8.953)\end{array}$ & & $\begin{array}{c}0.0258^{* *} \\
(0.013)\end{array}$ & & $\begin{array}{l}34.3240 * * * \\
(8.076)\end{array}$ \\
\hline Duration $\in[4.10]$ & & $\begin{array}{l}0.0495 * * * \\
(0.015)\end{array}$ & & $\begin{array}{c}51.0037 * * * \\
(11.931)\end{array}$ & & $\begin{array}{l}0.0131 \\
(0.016)\end{array}$ & & $\begin{array}{l}46.2568 * * * \\
(8.395)\end{array}$ \\
\hline Duration $\in[11.20]$ & & $\begin{array}{l}0.0344 \\
(0.022)\end{array}$ & & $\begin{array}{c}80.7907 * * * \\
(18.413)\end{array}$ & & $\begin{array}{l}0.0226 \\
(0.020)\end{array}$ & & $\begin{array}{c}65.1455^{* * *} \\
(14.058)\end{array}$ \\
\hline Duration $\in[21.30]$ & & $\begin{array}{c}0.0611^{* * *} \\
(0.023)\end{array}$ & & $\begin{array}{c}40.6297 * * * \\
(15.226)\end{array}$ & & $\begin{array}{l}0.1315 * * * \\
(0.031)\end{array}$ & & $\begin{array}{l}25.4766^{*} \\
(14.925)\end{array}$ \\
\hline Duration $\in[31.40]$ & & $\begin{array}{l}0.0874 * * * \\
(0.024)\end{array}$ & & $\begin{array}{c}38.6739 * * \\
(15.456)\end{array}$ & & $\begin{array}{l}0.2679 * * * \\
(0.035)\end{array}$ & & $\begin{array}{l}-0.5822 \\
(16.073)\end{array}$ \\
\hline Duration $\in[41.50]$ & & $\begin{array}{c}0.0896 * * * \\
(0.024)\end{array}$ & & $\begin{array}{c}35.5176 * * \\
(15.803)\end{array}$ & & $\begin{array}{c}0.3331 * * * \\
(0.031)\end{array}$ & & $\begin{array}{l}-13.4604 \\
(15.999)\end{array}$ \\
\hline Duration $\in[51.100]$ & & $\begin{array}{c}0.1413 * * * \\
(0.026)\end{array}$ & & $\begin{array}{l}23.1270 \\
(17.341)\end{array}$ & & $\begin{array}{c}0.3984 * * * \\
(0.030)\end{array}$ & & $\begin{array}{l}22.4302 \\
(16.221)\end{array}$ \\
\hline Duration $>100$ & & $\begin{array}{c}0.1718^{* * *} \\
(0.028)\end{array}$ & & $\begin{array}{c}45.5719 * * \\
(18.571)\end{array}$ & & $\begin{array}{c}0.4354 * * * \\
(0.044)\end{array}$ & & $\begin{array}{c}97.5605^{* * *} \\
(18.506)\end{array}$ \\
\hline Individual Covariates & YES & YES & YES & YES & YES & YES & YES & YES \\
\hline OCC FE & YES & YES & YES & YES & $\mathrm{NO}$ & $\mathrm{NO}$ & NO & NO \\
\hline Year FE & YES & YES & YES & YES & YES & YES & YES & YES \\
\hline State FE & YES & YES & YES & YES & YES & YES & YES & YES \\
\hline 1-digit SOC 2000 & NO & NO & NO & NO & $\mathrm{NO}$ & $\mathrm{NO}$ & NO & NO \\
\hline 2-digit SOC 2000 & NO & NO & NO & $\mathrm{NO}$ & NO & NO & NO & NO \\
\hline 3-digit SOC 2000 & YES & YES & YES & YES & NO & NO & NO & NO \\
\hline $\mathrm{H}_{0}:$ All Duration Dummies $=0$ & & 0 & & 0.000159 & & 0 & & 0 \\
\hline R-squared & 0.405 & 0.411 & 0.100 & 0.103 & 0.205 & 0.254 & 0.030 & 0.035 \\
\hline Observations & $10,829,059$ & $10,815,124$ & $10,829,059$ & $10,815,124$ & $1,585,098$ & $1,584,956$ & $1,585,098$ & $1,584,956$ \\
\hline
\end{tabular}

Note: All models perform coarsened exact matching on experience and marital status, and perform exact matching on race (white vs. others) and gender. Since some imbalances may still exist because we used only a few variables in the exact matching, we try to adjust for the remaining imbalances by controlling for the actual values of the covariates in a regression.; *** significant at the 0.01 level; ** significant at the 0.05 level; * significant at the 0.1 level; standard errors are constructed using the heteroscedasticity robust covariance matrix that allows for clustering at the state-occupation level. 
Appendix Table 11. Difference-in-Differences Coarsened Exact Matching Estimate of Grandfathering

\begin{tabular}{|c|c|c|c|c|c|c|c|c|}
\hline & (1) & $(2)$ & (3) & $(4)$ & $(5)$ & $(6)$ & $(7)$ & $(8)$ \\
\hline Control Group: & \multicolumn{4}{|c|}{$\begin{array}{c}\text { Relative to Individuals in Never Licensed Occupations } \\
\text { Throughout Our Period of Analysis }\end{array}$} & \multicolumn{4}{|c|}{$\begin{array}{l}\text { Relative to Unlicensed Workers in Universally Licensed } \\
\text { Occupations Prior to States Passing Licensing Statutes }\end{array}$} \\
\hline VARIABLES & \multicolumn{2}{|c|}{ Wage } & \multicolumn{2}{|c|}{ Hour } & \multicolumn{2}{|c|}{ Wage } & \multicolumn{2}{|c|}{ Hour } \\
\hline Licensure & $\begin{array}{l}-0.0076 \\
(0.020)\end{array}$ & & $\begin{array}{c}80.6397 * * * \\
(14.620)\end{array}$ & & $\begin{array}{c}0.0737 * * * \\
(0.018)\end{array}$ & & $\begin{array}{c}26.3230^{* * *} \\
(8.999)\end{array}$ & \\
\hline Duration $\in[0.3]$ & & $\begin{array}{l}-0.0508 \\
(0.039)\end{array}$ & & $\begin{array}{l}14.4563 \\
(24.190)\end{array}$ & & $\begin{array}{c}0.0941 * * * \\
(0.031)\end{array}$ & & $\begin{array}{c}5.7891 \\
(22.981)\end{array}$ \\
\hline Duration $\in[4.10]$ & & $\begin{array}{l}0.0544 \\
(0.036)\end{array}$ & & $\begin{array}{c}69.4117 * \\
(40.273)\end{array}$ & & $\begin{array}{c}0.0863 * * \\
(0.036)\end{array}$ & & $\begin{array}{l}31.9827 \\
(25.450)\end{array}$ \\
\hline Duration $\in[11.20]$ & & $\begin{array}{l}0.0047 \\
(0.031)\end{array}$ & & $\begin{array}{c}75.1245^{* * * *} \\
(26.706)\end{array}$ & & $\begin{array}{c}0.0722^{* * *} \\
(0.030)\end{array}$ & & $\begin{array}{l}27.1114 \\
(23.043)\end{array}$ \\
\hline Duration $\in[21.30]$ & & $\begin{array}{l}0.0509 \\
(0.040)\end{array}$ & & $\begin{array}{c}91.8508 * * * \\
(29.912)\end{array}$ & & $\begin{array}{c}0.2270 * * * \\
(0.042)\end{array}$ & & $\begin{array}{l}27.6861 \\
(22.189)\end{array}$ \\
\hline Duration $\in[31.40]$ & & $\begin{array}{c}0.0848 * * \\
(0.038)\end{array}$ & & $\begin{array}{l}70.8180 * * * \\
(27.047)\end{array}$ & & $\begin{array}{l}0.3765 * * * \\
(0.053)\end{array}$ & & $\begin{array}{l}-16.5489 \\
(23.056)\end{array}$ \\
\hline Duration $\in[41.50]$ & & $\begin{array}{c}0.0710^{*} \\
(0.041)\end{array}$ & & $\begin{array}{l}21.3039 \\
(54.526)\end{array}$ & & $\begin{array}{c}0.4544^{* * *} \\
(0.055)\end{array}$ & & $\begin{array}{c}-49.9530 * \\
(26.666)\end{array}$ \\
\hline Individual Covariates & YES & YES & YES & YES & YES & YES & YES & YES \\
\hline OCC FE & YES & YES & YES & YES & NO & NO & NO & NO \\
\hline Year FE & YES & YES & YES & YES & YES & YES & YES & YES \\
\hline State FE & YES & YES & YES & YES & YES & YES & YES & YES \\
\hline 1-digit SOC 2000 & NO & NO & NO & NO & NO & NO & NO & NO \\
\hline 2-digit SOC 2000 & NO & NO & NO & $\mathrm{NO}$ & NO & NO & NO & NO \\
\hline 3-digit SOC 2000 & YES & YES & YES & YES & NO & NO & NO & NO \\
\hline $\mathrm{H}_{0}$ : All Duration Dummies $=0$ & & 0.00221 & & 0.0160 & & 0 & & $2.23 e-05$ \\
\hline R-squared & 0.364 & 0.319 & 0.111 & 0.091 & 0.269 & 0.216 & 0.044 & 0.045 \\
\hline Observations & $9,552,482$ & 610,470 & $9,552,482$ & 610,470 & 311,215 & 17,123 & 311,215 & 17,123 \\
\hline
\end{tabular}

Note: All models perform coarsened exact matching on education, experience, and marital status, and perform exact matching on race (white vs. others) and gender. Since some imbalances may still exist because we used only a few variables in the exact matching, we try to adjust for the remaining imbalances by controlling for the actual values of the covariates in a regression.; *** significant at the 0.01 level; ** significant at the 0.05 level; * significant at the 0.1 level; standard errors are constructed using the heteroscedasticity robust covariance matrix that allows for clustering at the state-occupation level. 